\title{
Fruits, seeds and flowers from the Puryear clay pit (middle Eocene Cockfield Formation), western Tennessee, USA
}

\author{
Yuling $\mathrm{Na}$, Jane Blanchard, and Hongshan Wang
}

\begin{abstract}
Based on examination of 352 specimens collected from the Puryear clay pit (middle Eocene Cockfield Formation, Claiborne Group), Henry County, Tennessee, we recognize 72 fossil taxa/morphotypes of angiosperms. Thirty-two taxa/morphotypes are related to the following 12 extant families: Altingiaceae (2), Araliaceae (1), Arecaceae (2), Cannabaceae (1), Ceratophyllaceae (1), Euphorbiaceae (1), Fabaceae (11), Fagaceae (7), Juglandaceae (3), Oleaceae (1), Theaceae (1), and Ulmaceae (1). The rest (40 taxa/morphotypes) do not have enough diagnostic characters to assess their modern affinities. We establish two new fossil species Andrewsiocarpon puryearensis sp. nov. (Theaceae) and Paleopanax puryearensis sp. nov. (Araliaceae). Of the 72 taxa/ morphotypes recognized, 50 are unique to the Puryear locality (Cockfield Formation), 11 are shared with the Warman locality (Cockfield Formation), eight are shared with the Bovay and Bolden localities (Tallahatta Formation), and three are shared by all three localities. Of the 155 taxa/morphotypes recognized from the Bovay/Bolden, Warman, and Puryear localities, only three taxa/morphotypes are shared by all three localities. This study has expanded our knowledge of the Eocene plant diversity of the southeastern United States and has further confirmed our previous observation that there is a remarkable lack of species overlap among the localities examined to date.
\end{abstract}

Yuling Na. Research Center of Palaeontology \& Stratigraphy, Jilin University, Changchun 130026, China. nyl@jlu.edu.cn

Jane Blanchard. Florida Museum of Natural History, University of Florida, Gainesville, Florida 32611, USA. ojjhblanchard@aol.com

Hongshan Wang. Florida Museum of Natural History, University of Florida, Gainesville, Florida 32611, USA (corresponding author). hwang@flmnh.ufl.edu

Key words: new species; Andrewsiocarpon; Paleopanax; Angiosperms; Claiborne Group

Submission: 14 November 2019. Acceptance: 16 September 2020.

$\mathrm{Na}$, Yuling, Blanchard, Jane, and Wang, Hongshan. 2020. Fruits, seeds and flowers from the Puryear clay pit (middle Eocene Cockfield Formation), western Tennessee, USA. Palaeontologia Electronica, 23(3):a49. https://doi.org/10.26879/1042

palaeo-electronica.org/content/2020/3177-fossil-plants-from-tennessee

Copyright: October 2020 Paleontological Society.

This is an open access article distributed under the terms of Attribution-NonCommercial-ShareAlike 4.0 International (CC BY-NC-SA 4.0), which permits users to copy and redistribute the material in any medium or format, provided it is not used for commercial purposes and the original author and source are credited, with indications if any changes are made.

creativecommons.org/licenses/by-nc-sa/4.0/ 


\section{INTRODUCTION}

The Puryear clay pit is a classic middle Eocene fossil plant locality in western Tennessee, USA. Berry (1916, pg. 46) noted that "This is the most remarkable leaf-bearing clay that I have ever seen at any geologic horizon." Numerous taxa were published by Berry based upon material from Puryear and other middle and late Eocene localities in the southeastern United States (Berry, 1914a, 1914b, 1916a, 1916b, 1924, 1926, 1928, 1930). These comprehensive reports based on nearly 200 localities are outstanding contributions to paleobotany and continue to be important references for the study of fossil plants from the southeastern United States.

With the philosophy of finding modern counterparts for these fossil taxa, Berry (1914a, 1914b, 1916a, 1916b, 1924, 1926, 1928, 1930) assigned the majority of his leaf fossils to extant genera or families. His approach to the study of the Eocene flora has been replaced by a comparative approach proposed by Dilcher $(1971,1974)$ which considers details of fine venation and cuticular anatomy. Revisions of Berry's taxonomic relationships based on cuticle studies indicate that at least $60 \%$ of the taxonomic relationships of the fossils to modern families and genera published by Berry are incorrect (Dilcher, 1971).

Likewise, some of Berry's identifications of reproductive material also need revision. For example, a specimen from the Jackson Formation, McMurrains Crossing locality, Arkansas (Berry, 1924, pl. 33, figure 6, p. 169) was identified as a legume pod and was assigned to the modern genus Cassia. However, this specimen probably represents a caddisfly case. Some specimens assigned to Monocarpellites perkinsi and thought to be related to the Moraceae (Berry, 1922, pl. 7, figures 1-6, p. 16) were later revised to a fossil genus, Crepetocarpon (Dilcher and Manchester, 1988). Based on its similarities to the fruit morphology of the extant species Hipponmane mancinella, Crepetocarpon was considered to be related to the Euphorbiaceae (Dilcher and Manchester, 1988). Berry (1916b, 1924, 1930, 1941) identified five species of Nyssa endocarps. Whereas these assignments to the extant genus are probably correct, Dilcher and McQuade (1967) revised them, placing Nyssa wilcoxiana in synonymy with Nyssa eolignitica, and Wang et al. (2013) included some of them in Palmocarpon based on the presence of fiber strands on the endocarps.

Wang et al. (2013) recognized 60 species and morphotypes based on examination of 600 speci- mens of plant reproductive material collected from clay or mudstone horizons of the Cockfield Formation of the Claiborne Group from the Warman clay pit locality in Weakley and Henry Counties, Tennessee, USA (Figure 1). Most of the excavations at the Warman locality were in Weakley County with one small area extending into Henry County. The Warman clay pit was opened by the Spinks Clay Company in about 1959 and was closed in about 1990. For detailed locality information, see Wang et al., 2013, p. 3, figure 2.

Blanchard et al. (2016) reported 52 species and morphotypes based on investigation of 193 specimens of plant reproductive material collected from the Bovay and Bolden clay pits, in northern Mississippi, USA (Figure 1). Specimens from the Bovay and Bolden clay pits were treated in one paper because they were all collected from the upper portion of the Tallahatta Formation of the Claiborne Group and the two localities are only about $15 \mathrm{~km}$ apart. For detailed locality information, see Blanchard et al. (2016, p. 3, figure 3).

In this paper, we provide a comprehensive examination of reproductive material (including redocumenting specimens that are published elsewhere) collected from the Puryear locality, Tennessee and stored at the Florida Museum of Natural History, Gainesville, Florida, and the George Safford Torrey Herbarium (CONN), University of Connecticut, Storrs, Connecticut, USA. We report 72 fossil taxa/morphotypes based on reproductive material from the Puryear locality. Table 1 lists all taxa recognized so far from Bovay/Bolden, Puryear, and Warman localities.

\section{MATERIAL AND METHODS}

All fossil specimens discussed in this paper are compressions or impressions collected from the Puryear clay pit in western Tennessee (Figure 1) over a 10-year period beginning in 1959 by Professor David Dilcher and his students and colleagues. Specimens housed in the Paleobotany Collection at the Florida Museum of Natural History, Gainesville, Florida, are cataloged using the prefix UF15820-, and specimens housed in the George Safford Torrey Herbarium at the University of Connecticut, Storrs, Connecticut are cataloged using the prefix CONN-.

The Puryear clay pit is located immediately off $S$ McDonald Rd, about $0.8 \mathrm{~km}$ south of Puryear,

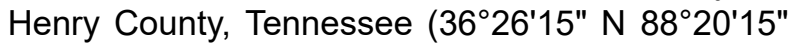
W). The clay pit was opened in 1904 (Nelson, 1911) and was closed in the early 1990s when it 


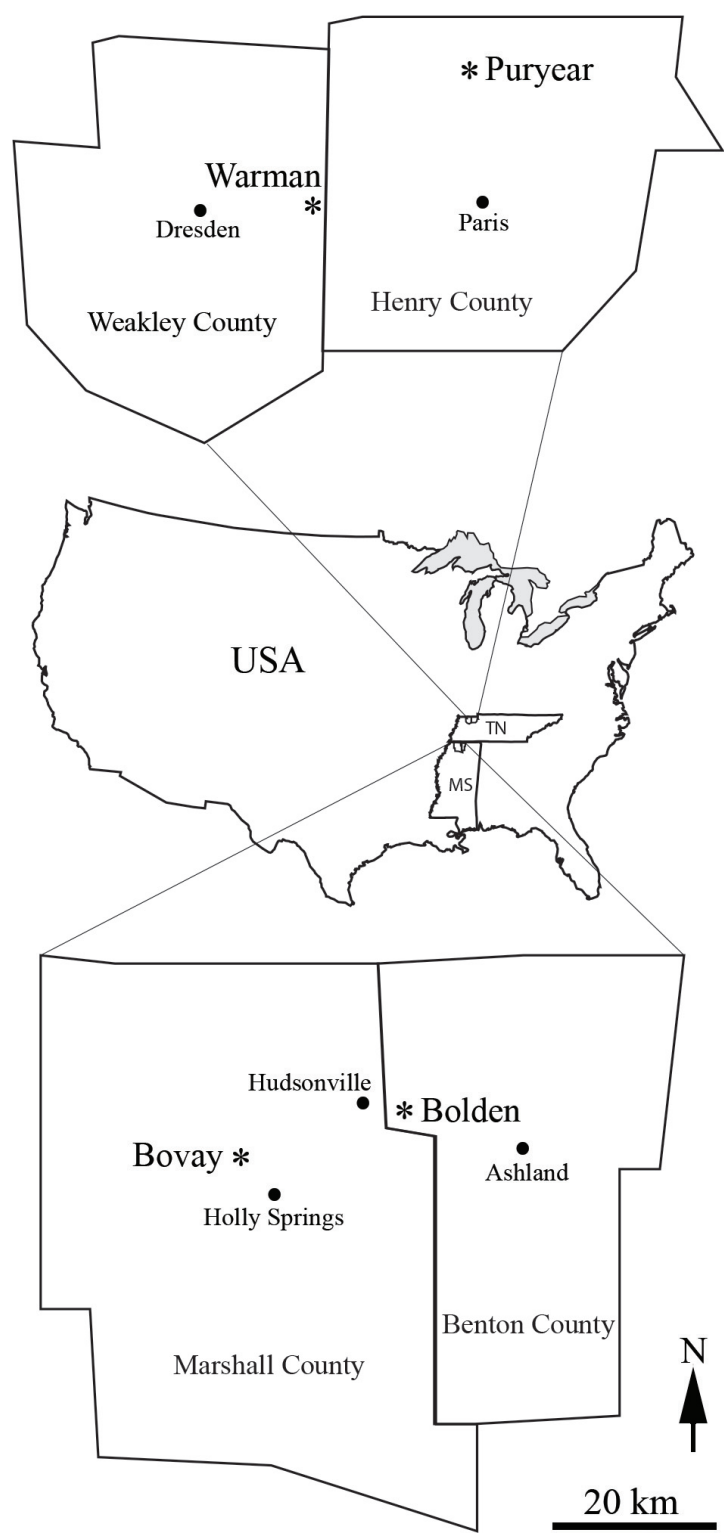

FIGURE 1. Locations of the Puryear (UF15820) and Warman (UF15826) clay pits in western Tennessee (TN) and the Bovay (UF15737) and Bolden (UF15738) clay pits in northern Mississippi (MS), southeastern USA. Scale bar is for Benton and Marshall counties of Mississippi and Henry and Weakley counties of Tennessee.

TABLE 1. All taxa/morphotypes reported from the Puryear locality, western Tennessee, USA. The table also lists each taxon/morphotype's organ type, proposed modern affinity, and its figure numbers in this paper and in Wang et al. (2013; Warman locality, western Tennessee) and in Blanchard et al. (2016; Bovay and Bolden localities, northern Mississippi). "+" indicates a taxon/ morphotype is present at a locality. Available as spreadsheet file for download at https://palaeo-electronica.org/ content/2020/3177-fossil-plants-from-tennessee.

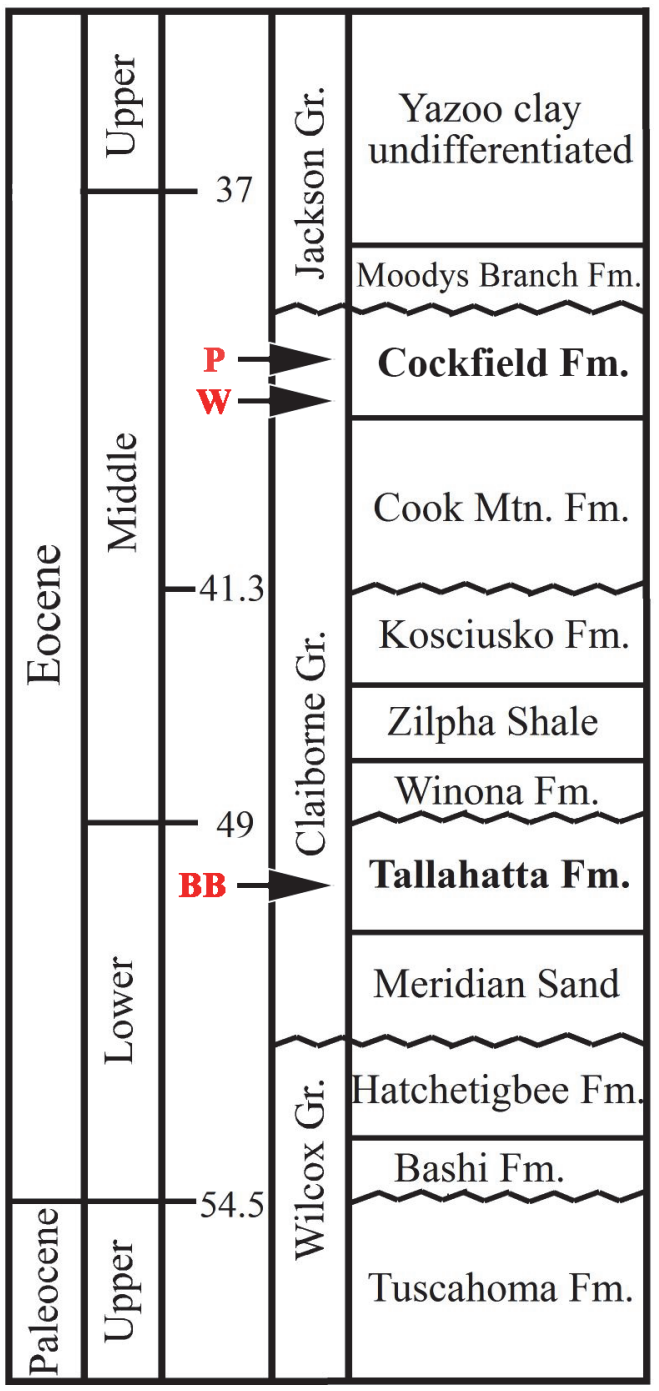

FIGURE 2. Simplified stratigraphic column of the middle Eocene Claiborne Group in northern Mississippi and western Tennessee (after Dockery, 1996). Specimens examined in this paper were collected from the Cockfield Formation at the Puryear locality (P), Tennessee. Specimens from other localities used for comparison were collected from the Tallahatta Formation at the Bovay and Bolden localities (BB), Mississippi and the Cockfield Formation at the Warman clay pit (W; stratigraphically lower than the Puryear locality), Tennessee.

was mined out. This is the same locality from which most of Berry's (1916) specimens were collected.

Palynological data from the Claiborne Group in Henry County, Tennessee, indicate that these clay lenses (or clay pits) are best considered to be late middle Eocene Cockfield Formation of the Claiborne Group (Figure 2; Tschudy, 1973; Elsik, 1974; Elsik and Dilcher, 1974; Dockery, 1996). Based upon their vertical positions determined 
TABLE 2. Suggested sequence of deposition of clay pits in western Tennessee (Modified from Potter and Dilcher, 1980).

\begin{tabular}{ccc}
\hline & Youngest & \\
\hline Breedhive pit & & Rushing pit \\
New Puryear pit & & Lawrence pit and Atkins pit \\
Spinks pit & Miller pit \\
Foundry Hill pits & & Grable pit \\
Puryear pit & All very close in age & Hayes pit \\
Buchanan pit & & Carauthers pit \\
Martin pit & & Liberty Church pits \\
Cottage Grove pits & & Rancho pit \\
& & Young pit \\
& Warman pit \\
& & Gleason area pits \\
\hline
\end{tabular}

from topographic maps and overburden exposures observed in the field, Potter and Dilcher (1980, figs. $8.4,8.5$, table 8.1) compared 19 clay pits in western Tennessee. They suggested that (1) all clay pits appear to be restricted to the upper middle Eocene (Cook Mountain and Cockfield formations of the Claiborne Group) and (2) the Puryear clay pit is of intermediate age among all clay pits within late middle Eocene (Potter and Dilcher, 1980; Table 2).

The nature of the sediments in these clay pits, including the Puryear locality, indicates that they are the result of filling of abandoned river channels or of a typical oxbow lake depositional system (Dilcher, 1971; Potter, 1976; Potter and Dilcher, 1980). Three dimensional studies of several clay lenses having sharp and distinct lower boundaries with finely laminated bedding suggest rapidly formed deposits during a 2000- to 3000year period with high rates of infilling by clay-sized particles (Potter and Dilcher, 1980).

Specimens that have been published previously and have sufficient characters to assess their modern affinities are assigned to extant families. The relationships with modern families of some specimens, for example, cf. Populus sp., that lack diagnostic characters, are inferred from their cooccurrence with other organs (e.g., leaves) at the same locality or at localities of equivalent age. These families are arranged according to the Angiosperm Phylogeny Group (APG IV, 2016). The following databases and websites were consulted: The Families of Flowering Plants (Watson and Dallwitz, 1992 onwards), Legume (Fabaceae) Fruits and Seeds (Kirkbride et al., 2015), Family Guide for Fruits and Seeds (Kirkbride et al., 2006), The International Plant Names Index (https:// www.ipni.org), and Angiosperm Phylogeny Website (Stevens, 2001 onwards). The specimens, whose modern affinities are uncertain, or cannot be related to the familial or higher rank, are classified into morphotypes with informal names. Their arrangement in the text is by organ type in the following order: flowers, inflorescences, infructescences, fruits, seeds, and other undermined. We add "Claiborne" to a morphotype name in order to refer to its occurrence in the Claiborne Group. For example, we use "Claiborne Floral Type" to name flowers and their disarticulated parts. For morphotypes whose modern affinities are relatively certain, we add a familial or ordinal name to indicate their possible placement within an extant family or order. For example, we use "Claiborne Fagaceae Fruit Type 1" to indicate a fruit type closely related to the modern family Fagaceae. Regardless of their occurrences at different localities within the Claiborne Group, we number different morphotypes of the same organ consecutively, using Arabic numerals. For consistency, we also renamed the morphotypes from the Warman clay pit, Tennessee (Wang et al., 2013; Table 1). Following the description of each taxon/morphotype, the total number of specimens examined and catalog numbers for the illustrated specimens are listed.

\section{SYSTEMATIC PALAEONTOLOGY}

Order ARECALES Bromhead, 1840

Family ARECACEAE von Berchtold and J. Presl, 1820

Claiborne Arecaceae Infructescence Type 1 Figure 3

Description. Laterally preserved, pedunculate infructescences consisting of at least four tightly clustered, orbicular, sessile, fibrous fruits ca. 5-7 


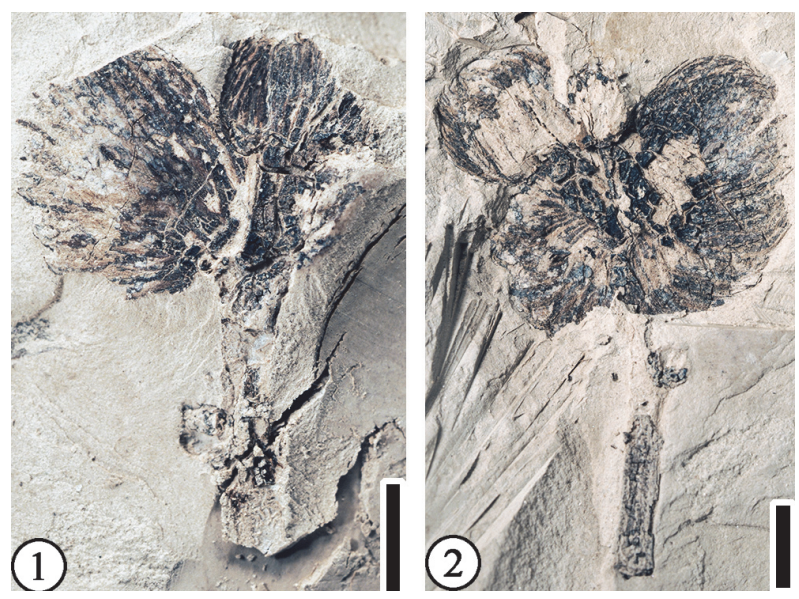

FIGURE 3. Claiborne Arecaceae Infructescence Type 1: 1) UF15820-059399, showing an infructescence with at least two terminal sessile fruits and a lateral projection; 2) UF15820-059399, counterpart showing at least three fruits. All scale bars equal $3 \mathrm{~mm}$.

$\mathrm{mm}$ in diameter. Peduncle ca. $9.5 \mathrm{~mm}$ long and 1.5 $\mathrm{mm}$ wide. A lateral projection ca. $1.5 \mathrm{~mm}$ in diameter present, ca. $2 \mathrm{~mm}$ below the terminal cluster of fruits.

Number of specimens examined. 2. UF15820059399, 059399'.

Remarks. The fibrous fruits are similar to the arecaceous endocarps from the Lamkin clay pit, Graves County, Kentucky described by Grote (1989, pp. 172-176, pl. VIII; Figure 4), except that the fruits from the Puryear locality are smaller (5-7 $\mathrm{mm}$ in diameter vs $18 \mathrm{~mm}$ long and $14 \mathrm{~mm}$ wide). It is possible that these fruits represent the same species but are not fully mature. The subterminal projection may represent the base of a detached fruit or another branch of the fruiting axis.

Based upon the material from the Lamkin clay pit, Grote (1989) suggested that the characters of this fruit type, including a thin exocarp, a fibrous mesocarp, and an endocarp circular in transverse section with a tapering trigonal apex, and possible ruminate endosperm, indicate a relationship with the Arecaceae. In this report, we agree with Grote's (1989) assignment and treat this fossil fruit type as extinct member of the Arecaceae. As suggested by Grote (1989, p. 175), a detailed examination of the extant fruits and seeds of the entire family may yield closer relatives.

This fruit type from the Puryear clay pit is also similar to Castanopsoidea cupules in size, but they differ in that the fibers of the fruits from Puryear cover the entire fruit body while the cupules of
Castanopsoidea are more elongate in shape and only have short scales.

\section{Claiborne Arecaceae Fruit Type 1 Figure 4}

Description. Laterally compressed fruit with attached fibers, ca. $15 \mathrm{~mm}$ wide at the middle and ca. $18 \mathrm{~mm}$ long. Slightly concave at the base. Fibers curving around the fruit and extending from the base to beyond the apex.

Number of specimens examined. 1. UF15820059477, 059477'.

Remarks. This specimen probably represents a palm endocarp with mesocarp fibers. This is probably the same fruit type described by Grote (1989, pp.172-176, pl. VIII, figures 1-8) because of their similar size and the presence of fibers. Grote (1989) reported 36 charcoalized, fibrous fruits from the Lamkin clay pit, Kentucky. Based on the characters that the fruit has a thin exocarp, fibrous mesocarp, and one seed with ruminate endosperm, he suggested that these fossils may be related to the Arecaceae. However, these characters are found in various groups throughout the large family, it is difficult to relate this fruit type to a particular tribe or a genus.

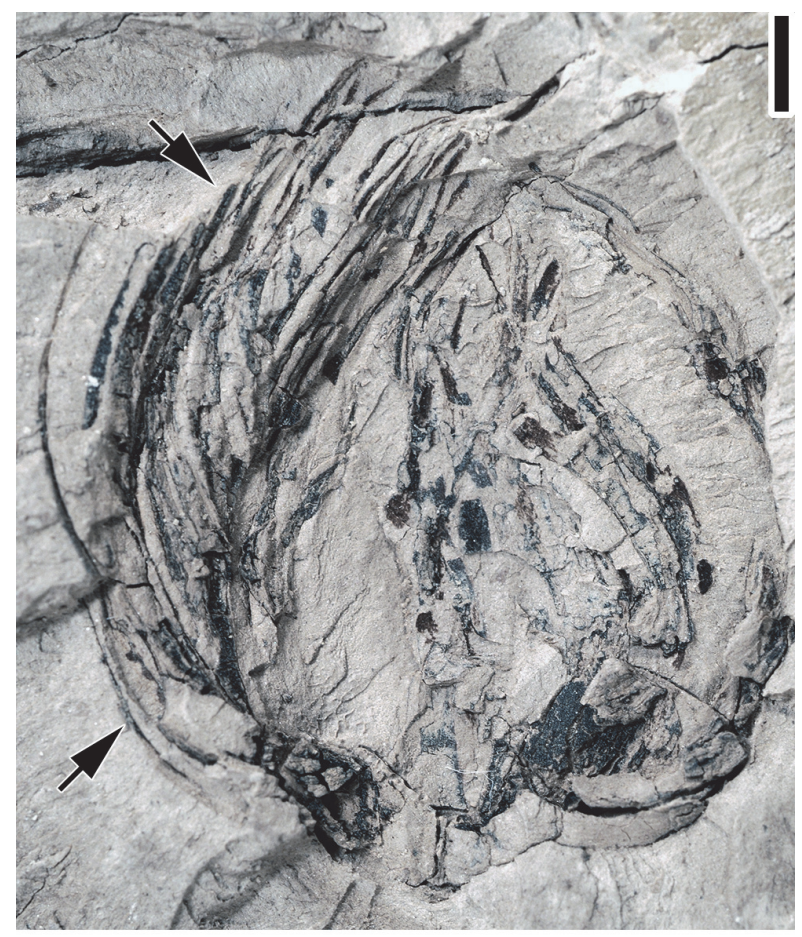

FIGURE 4. Claiborne Arecaceae Fruit Type 1: UF15820-059477, laterally compressed fruit with fibers. Note that curved fibers (indicated by arrows) extend from the base to beyond the apex of the fruit. Scale bar equals $2 \mathrm{~mm}$. 
Order CERATOPHYLLALES Link, 1829

Family CERATOPHYLLACEAE Gray, 1821

Genus CERATOPHYLLUM Linnaeus, 1753

Ceratophyllum muricatum Chamisso subspecies incertum (Berry) Herendeen, Les and Dilcher 1990 Figure 5

Description. Spiny fruit $11 \mathrm{~mm}$ long and $8 \mathrm{~mm}$ wide. Lateral spines $2.0-3.8 \mathrm{~mm}$ long.

Number of specimens examined. 2. CONN-Q1203, Q12-04.

Remarks. Based on fruit size and the presence of lateral spines, these two specimens from Puryear belong to the same taxon reported by (Berry, 1930, p. 71 , pl. 33, figures 7-8) and revised by Herendeen et al. (1990, p. 8, figure 8). Fossil fruits of Ceratophyllum have been reported from the Late Cretaceous of Canada (Serbet et al., 2008) and Mexico (Estrada-Ruiz et al., 2009).
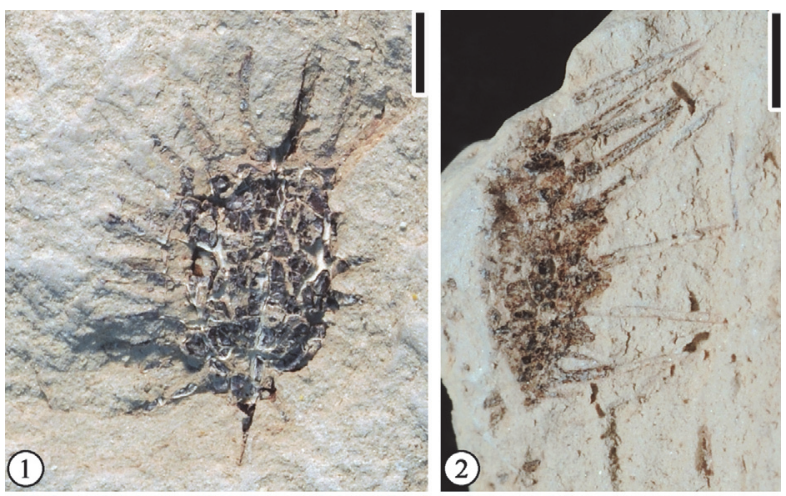

FIGURE 5. Ceratophyllum muricatum Chamisso subspecies incertum (Berry) Herendeen, Les and Dilcher, 1990: 1) CONN-Q12-03, specimen showing fruit body and lateral spines; 2) CONN-Q12-04, an incomplete fruit showing lateral spines. All scale bars equal $2 \mathrm{~mm}$.

Order FABALES Bromhead, 1838

Family FABACEAE Lindley, 1836

Genus PROTOMIMOSOIDEA Crepet and Taylor, 1986

Protomimosoidea buchananensis Crepet and Taylor, 1986

1986 Protomimosoidea buchananensis Crepet and Taylor, p. 555, figs. 1-22.

2013 Protomimosoidea buchananensis Crepet and Taylor; Wang, Blanchard, and Dilcher, p. 15, fig. 12.

\section{Figure 6}

Description. Laterally preserved flower $3 \mathrm{~mm}$ long and $2 \mathrm{~mm}$ wide (excluding filaments and pedicel). Seven incomplete filaments $4 \mathrm{~mm}$ long and $0.2 \mathrm{~mm}$

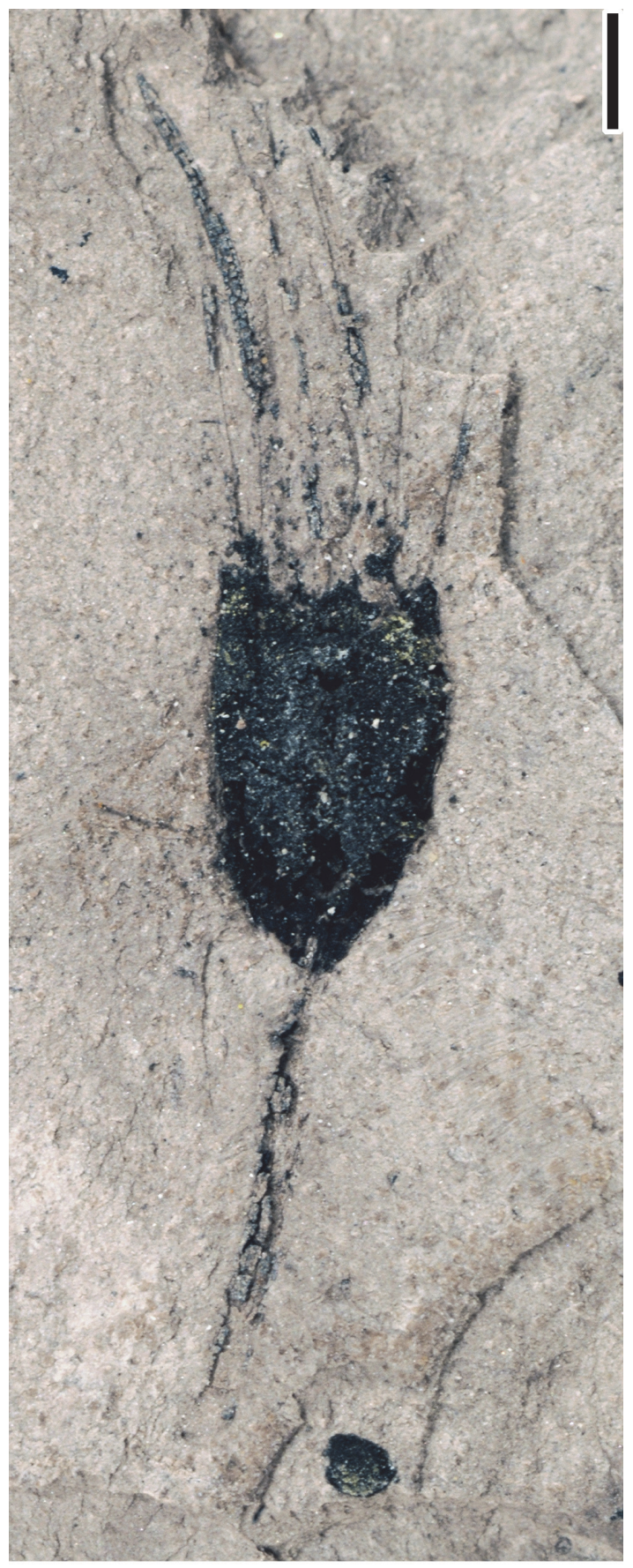

FIGURE 6. Protomimosoidea buchananensis Crepet and Taylor, 1986: UF15820-061118, flower showing multiple filaments with anthers missing. Scale bar equals $1 \mathrm{~mm}$.

wide; anthers missing. Pedicel $4 \mathrm{~mm}$ long and 0.2 $\mathrm{mm}$ wide.

Number of specimens examined. 1. UF15820061118.

Remarks. This specimen is not as well-preserved as those described from the Warman locality, Ten- 
nessee (Wang et al., 2013, p. 15, figure 12), and the Bovay locality, Mississippi (Blanchard et al., 2016, pp. 9-11, figures 5-7). Based on the size and gross shape of the flower, and the presence of multiple filaments, we assign the Puryear specimen to the same species.

\section{Claiborne Fabaceae Floral Type 1 Figure 7}

Description. Laterally compressed flower ca. 1.2 $\mathrm{cm}$ long and $1 \mathrm{~cm}$ wide. Three perianth parts visible: two small perianth parts ca. $5 \mathrm{~mm}$ long and 2 $\mathrm{mm}$ wide with acute apices; a single, larger perianth part ca. $7 \mathrm{~mm}$ long and $4 \mathrm{~mm}$ wide with a rounded apex. Pedicel ca. $4 \mathrm{~mm}$ long and $1 \mathrm{~mm}$ wide.

Number of specimens examined. 1. UF15820061142.

Remarks. In addition to this flower from the Puryear locality, Blanchard et al. (2016, p. 15, figure

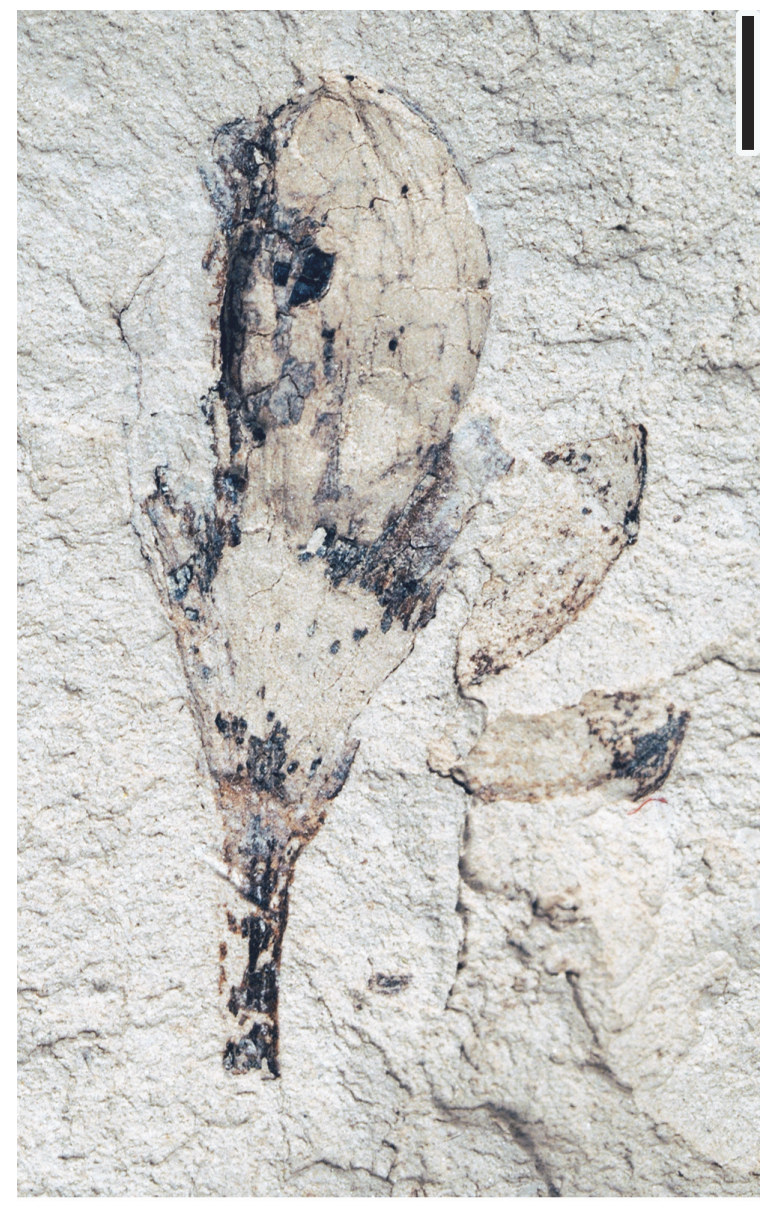

FIGURE 7. Claiborne Fabaceae Floral Type 1: UF15820-061142, a laterally compressed flower with three perianth parts and pedicel. Scale bar equals 2 $\mathrm{mm}$.
11) described another specimen from the Bovay clay pit, Mississippi. The morphology of this floral type is similar to Barnebyanthus buchananensis Crepet and Herendeen, papilionoid flowers reported from the Buchanan clay pit, Henry County, Tennessee (Crepet and Dilcher, 1992, p. 47, figures 1-4). The Bovay and Puryear specimens are not as well-developed as the Buchanan flower, but it is possible that they represent the same taxon as $B$. buchananensis Crepet and Herendeen.

\section{Claiborne Fabaceae Floral Type 2}

Figure 8

Description. Laterally compressed flower $7 \mathrm{~mm}$ long and $4 \mathrm{~mm}$ wide at the widest point. Stamens numerous, filaments ca. $1 \mathrm{~mm}$ long, anthers 0.5 $\mathrm{mm}$ in diameter. Pedicel $2 \mathrm{~mm}$ long and $0.8 \mathrm{~mm}$ wide.

Number of specimens examined. 1. UF15820043606.

Remarks. The presence of numerous stamens with short filaments is consistent with the Bovay and Bolden specimens described by Blanchard et al. (2016, pp.14-15, figure 12). Therefore, we assign them to the same floral type.

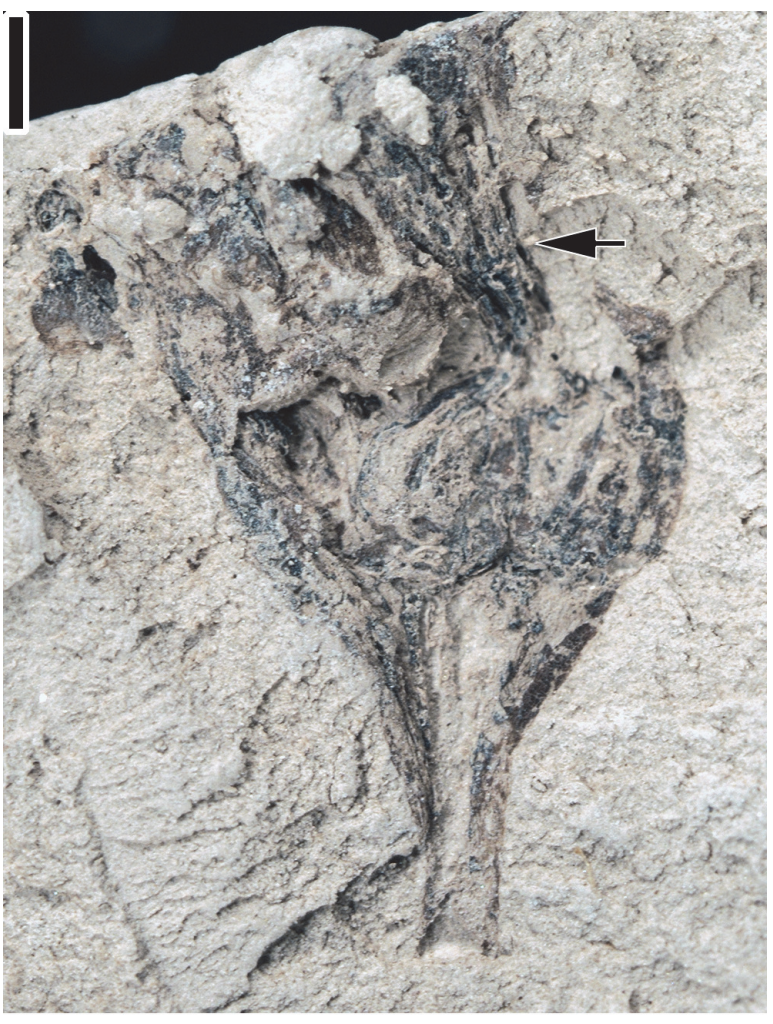

FIGURE 8. Claiborne Fabaceae Floral Type 2: UF15820-043606, flower with numerous stamens (indicated by arrow). Scale bar equals $1 \mathrm{~mm}$. 


\section{Claiborne Fabaceae Floral Type 3 Figure 9}

Description. Laterally preserved flower $7 \mathrm{~mm}$ long (excluding pedicel). Pedicel $5 \mathrm{~mm}$ long and $0.2 \mathrm{~mm}$ wide. Two perianth parts (petals?) observed, 1.5 $\mathrm{mm}$ long and $0.5 \mathrm{~mm}$ wide. Expanding ovary present, $1 \mathrm{~mm}$ long and $0.6 \mathrm{~mm}$ wide, with an apical style about $1 \mathrm{~mm}$ long. One anther present, 0.7 $\mathrm{mm}$ long and $0.5 \mathrm{~mm}$ wide.

Number of specimens examined. 1. UF15820043630.

Remarks. This specimen shows two perianth parts which probably are petals, an expanding ovary and a long pedicel. Compared with the specimen assigned to Claiborne Fabaceae Floral Type 1 from the Bovay locality (Blanchard et al., 2016, p. 14 , figure 11), this flower is much smaller, and it has a longer pedicel. The specimen from the Bovay locality probably belongs to the same species, Barnebyanthus buchananensis Crepet and Herendeen (1992), reported from the Buchanan locality (UF15806), Tennessee (Crepet and Herendeen, 1992). The long pedicel $(5 \mathrm{~mm})$ and small size $(7 \mathrm{~mm})$ of the Puryear specimen may warrant a new type of Fabaceae flower if future collection of more specimens demonstrates other character differences.

Genus CAESALPINIA Linnaeus, 1753 Caesalpinia claibornensis Herendeen and Dilcher, 1991

Figure 10

1991 Caesalpinia claibornensis Herendeen and Dilcher, p. 3, figs. 1-12.

2013 Caesalpinia claibornensis Herendeen and Dilcher; Wang, Blanchard, and Dilcher, p. 15, figs. $13.4-5$.

Description. "The fossil fruits are $5.1-8.1 \mathrm{~cm}$ long $(\bar{x}=6.9 \mathrm{~cm}), 1.2-2.1 \mathrm{~cm}$ wide $(\bar{x}=1.7 \mathrm{~cm}$, excluding the wing) and have a continuous vascularized wing along the placental suture that is usually wider at the fruit center than at the ends. The fruits are thin and membranous. The fruit base is acute to obtuse, the apex is blunt and rounded or occasionally mucronate with a persistent style base (ca. $1 \mathrm{~mm}$ long). The fruits are short stipitate (ca. $2 \mathrm{~mm}$ ) and contain three to seven ovules. The fruit valve venation consists of numerous, closely spaced primary veins that arise from the placental and nonplacental sutures at $90^{\circ}$ angles. These veins divide and anastomose to form a fine reticulum. The wing venation consists of a poorly organized storied looping pattern in which veins arise from the placental suture, divide several times, and return

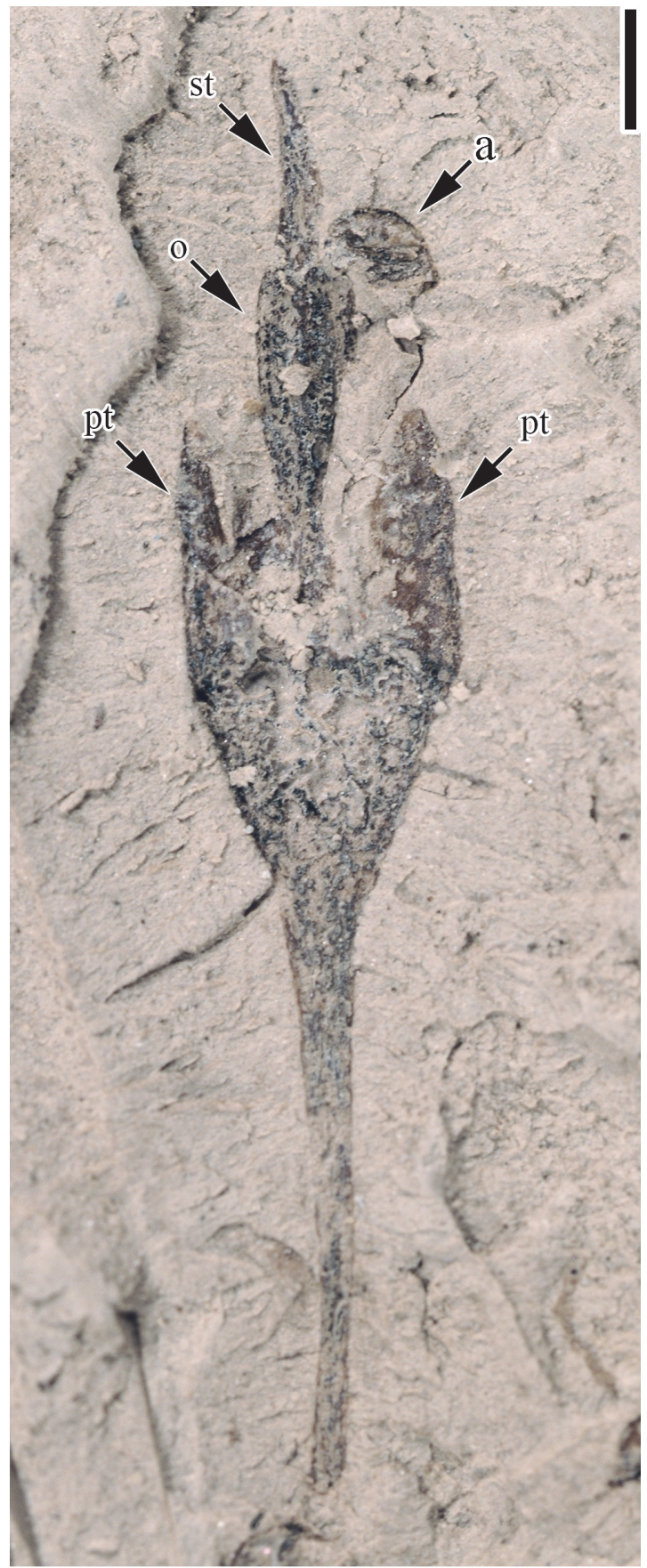

FIGURE 9. Claiborne Fabaceae Floral Type 3: UF15820-043630, flower showing at least two valvate petals (pt), anther (a), style (st), and ovary (o). Scale bar equals $1 \mathrm{~mm}$.

toward the suture. The valve venation is often better preserved than is the wing venation." (Herendeen and Dilcher, 1991, p. 3)

Number of specimens examined. 2. UF15820$005854,005855$. 


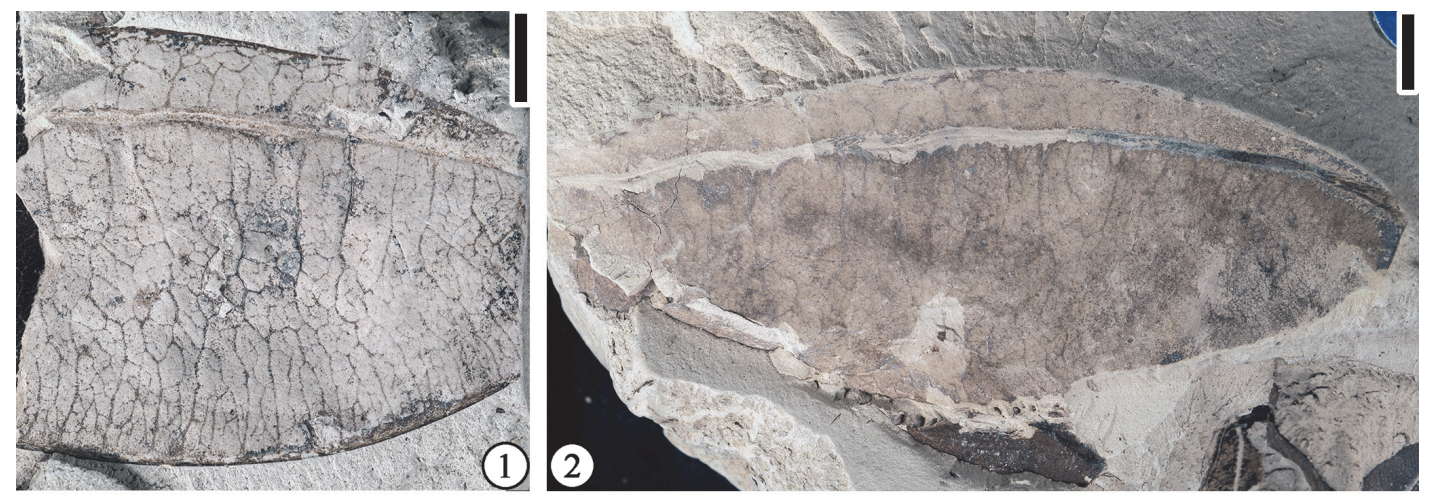

FIGURE 10. Caesalpinia claibornensis Herendeen and Dilcher, 1991: 1) UF15820-005854, incomplete fruit showing both valve and wing venation; 2) UF15820-005855, incomplete fruit showing both valve and wing venation. All scale bars equal $5 \mathrm{~mm}$.

Remarks. These are the two paratype specimens described and illustrated by Herendeen and Dilcher (1991, p. 3, figures 11, 12). We re-illustrate them here to demonstrate the occurrence of this species at the Puryear locality, Tennessee.

Three species were recognized within Caesalpinia L. subgenus Mezoneuron (Desf.) Vidal ex Herendeen and Zarucchi by Herendeen and Dilcher (1991). Eighteen specimens of Caesalpinia claibornensis are recognized from the Eocene Claiborne Group, two specimens of Caesalpinia flumen-viridensis from the Eocene Green River Formation in southwestern Wyoming, and 12 specimens of Caesalpinia spokanensis from the Miocene Latah Formation near Spokane, Washington and Coeur d'Alene, Idaho, and the Clarkia, Oviatt Creek, and Whitebird floras in Idaho. These specimens, which are the only reliable evidence of $C$. subg. Mezoneruron in the fossil record, show that this group had a broad geographic and temporal range in North America before its extinction, perhaps in the late Miocene (Herendeen and Dilcher, 1991).

\section{cf. Caesalpinia sp.}

Figure 11

1992 cf. Caesalpinia sp., Herendeen, p. 94, figs. 2533.

Description. "The fruits are 4.5-6.1 cm long, 1.3$1.9 \mathrm{~cm}$ wide; apex and base angular, acute to obtuse; fruits sessile; margins straight or with one shallow constriction; seeds 3-7, symmetrical, transverse; seed chambers well developed; sutures narrow; parallel oblique striations and fractures on valves; fruits dehiscent, valves twisting." (Herendeen, 1992, p. 94).

Number of specimens examined. 6. UF15820005862, 008961.
Remarks. Herendeen (1992) reported six specimens from the Puryear locality (two are illustrated here) and one specimen from the Lawrence clay pit, Tennessee. The dehiscence of the fruits is indicated by the presence of parallel, oblique striations on the fruit valves, and the symmetrical seed outline is suggestive of a caesalpinioid/mimosoid affinity.

\section{Genus CLADRASTIS Rafinesque, 1824 cf. Cladrastis sp.}

Figure 12

1992

cf. Cladrastis sp., Herendeen, p. 114, figs. 138141.

Description. "The fruits are $3.8+\mathrm{cm}$ long, 1.3-1.5 $\mathrm{cm}$ wide; apex obtuse to acute, base acute, stipitate; placental suture narrowly winged (1-2 mm), nonplacental suture sometimes attenuate; fruit margins with one to several shallow constrictions; ovules 1-2, oblique; seeds parallel to fruit margins; fruits thin, membranous, indehiscent" (Herendeen, 1992, p. 114).

Number of specimens examined. 4. UF15820005419, 005419', 009012.

Remarks. Here we illustrate two of the four specimens reported from the Puryear clay pit by Herendeen (1992, p. 113, figures 138-141). He suggested that these fossils are similar to extant Cladrastis fruits in size and shape, narrow wing on the placental suture, parallel seeds, and membranous texture.

Leaves of Gleditsiophyllum eocenicum (Herendeen, 1992, figures 145-157), similar to several extant Asian rather than extant southeastern North American Cladrastis species (Herendeen, 1992, figures 158-165), are common in many Claiborne localities, including Bovay, Warman, and Puryear. 


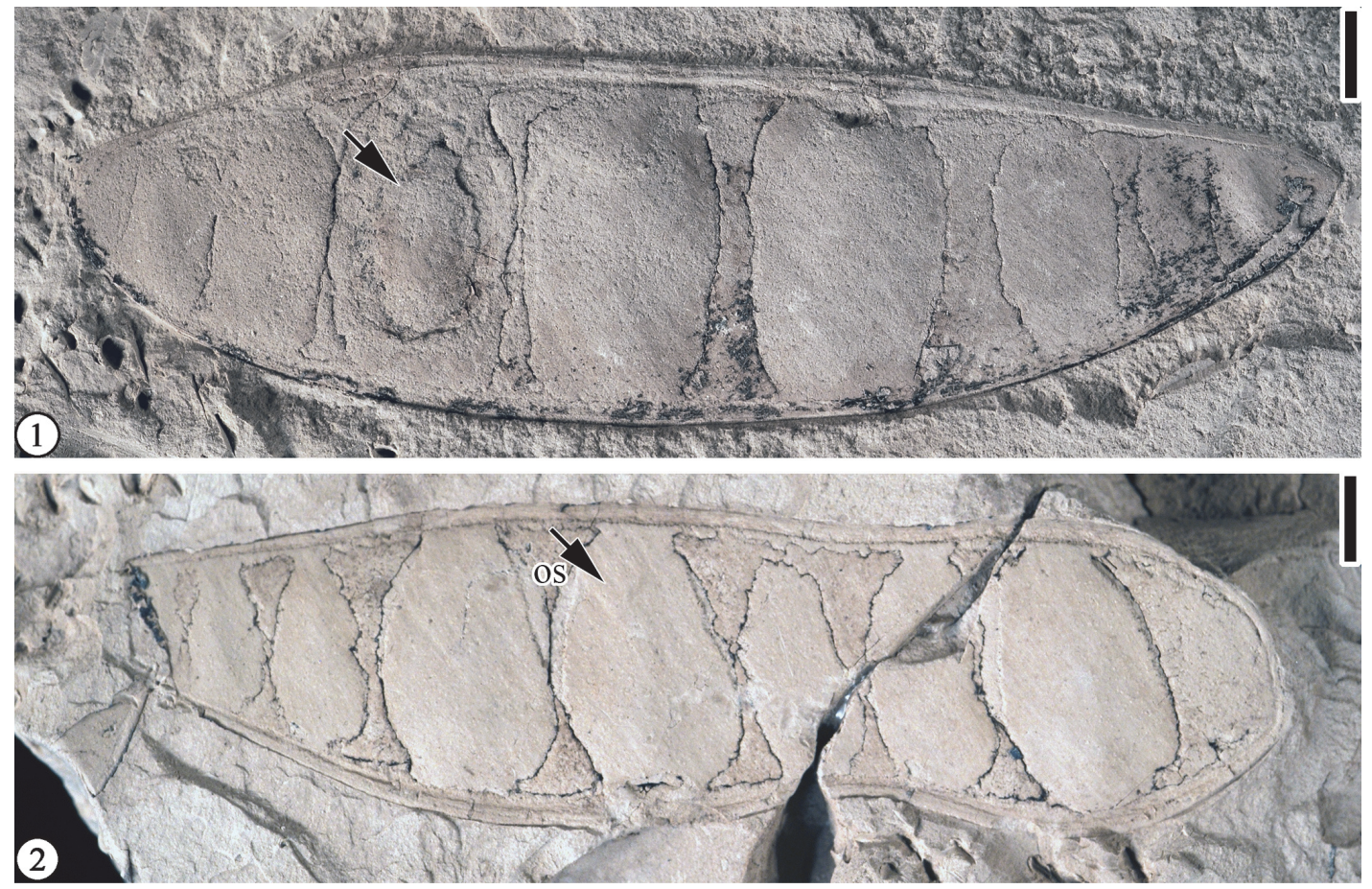

FIGURE 11. cf. Caesalpinia sp.: 1) UF15820-005862, fruit showing at least seven seed chambers, one seed impression in valve (indicated by arrow), and angular apex on the right. Scale bar equals $4 \mathrm{~mm}$; 2) UF15820-008961, fruit showing seven seed chambers, oblique striations (os), and obtuse apex on the right. Scale bar equals $4 \mathrm{~mm}$.

\section{"Fruits similar to the Sophoreae"}

Figure 13

Description. "The fruits are $3.0-3.5 \mathrm{~cm}$ long, 0.9 $1.7 \mathrm{~cm}$ wide; apex rounded, base abruptly rounded to truncated; margins straight to slightly constricted; fruits thin and membranous; ovules 3-4, oblique, asymmetrical; funiculus attached to seed subapically; seeds transverse; seed chambers not evident; sutures not prominent; narrow wing along placental suture." (Herendeen, 1992, p. 123)

Number of specimens examined. 3. UF15820$000025 a, 005847$.

Remarks. Herendeen (1992, p. 123, figures 211221) reported eight specimens from the Claiborne Group from the Puryear locality and the Buchanan locality. The ovule outline and attachment are suggestive of their relationship with the Papilionoideae (Herendeen, 1992).

\section{"Short, broad winged fruit"}

Figure 14

Description. "The fruits are $3.0-6.0+\mathrm{cm}$ long, 1.6 $-3.2 \mathrm{~cm}$ wide; apex rounded to attenuate; base abruptly rounded to attenuate; fruits stipitate, $5 \mathrm{~mm}$ long; margins straight to slightly constricted; nonvascularized wing on placental suture, up to $2 \mathrm{~mm}$ wide; seeds $1-2$, possibly round; valves thin and membranous, venous; orientation of major veins variable, from approximately perpendicular to oblique; calyx open, radially symmetrical." (Herendeen, 1992, p. 129)

Number of specimens examined. 4. UF15820005834, 007679, 007082, 007696.

Remarks. Herendeen (1992, p. 129, figures 231238) reported eight specimens from the Bovay and Bolden clay pits, Mississippi, and the Puryear clay pit, Tennessee. Blanchard et al. (2016, p. 13, figure 10) re-illustrated two specimens from the Bovay and Bolden pits. Here we re-illustrate four specimens from the Puryear clay pit.

\section{cf. Leguminosites ingafructoides Berry, 1930}

Figure 15

1930 Leguminosites ingafructoides Berry, p. 87, pl. 13 , fig. 8 , pl. 29, fig. 1.

1992 cf. Leguminosites ingafructoides Berry, Herendeen, p. 133, figs. 244-245.

Description. "The fruit is $10.3 \mathrm{~cm}$ long, $3.1 \mathrm{~cm}$ wide; apex rounded, base obtuse; fruit stipitate, 5 $\mathrm{mm}$ long; margins with a single constriction; sutures thick, $2.4 \mathrm{~mm}$; numerous parallel oblique striations; fruit dehiscent, valves twisting."(Herendeen, 1992, p. 133)

Number of specimens examined. 1. UF15820005843 

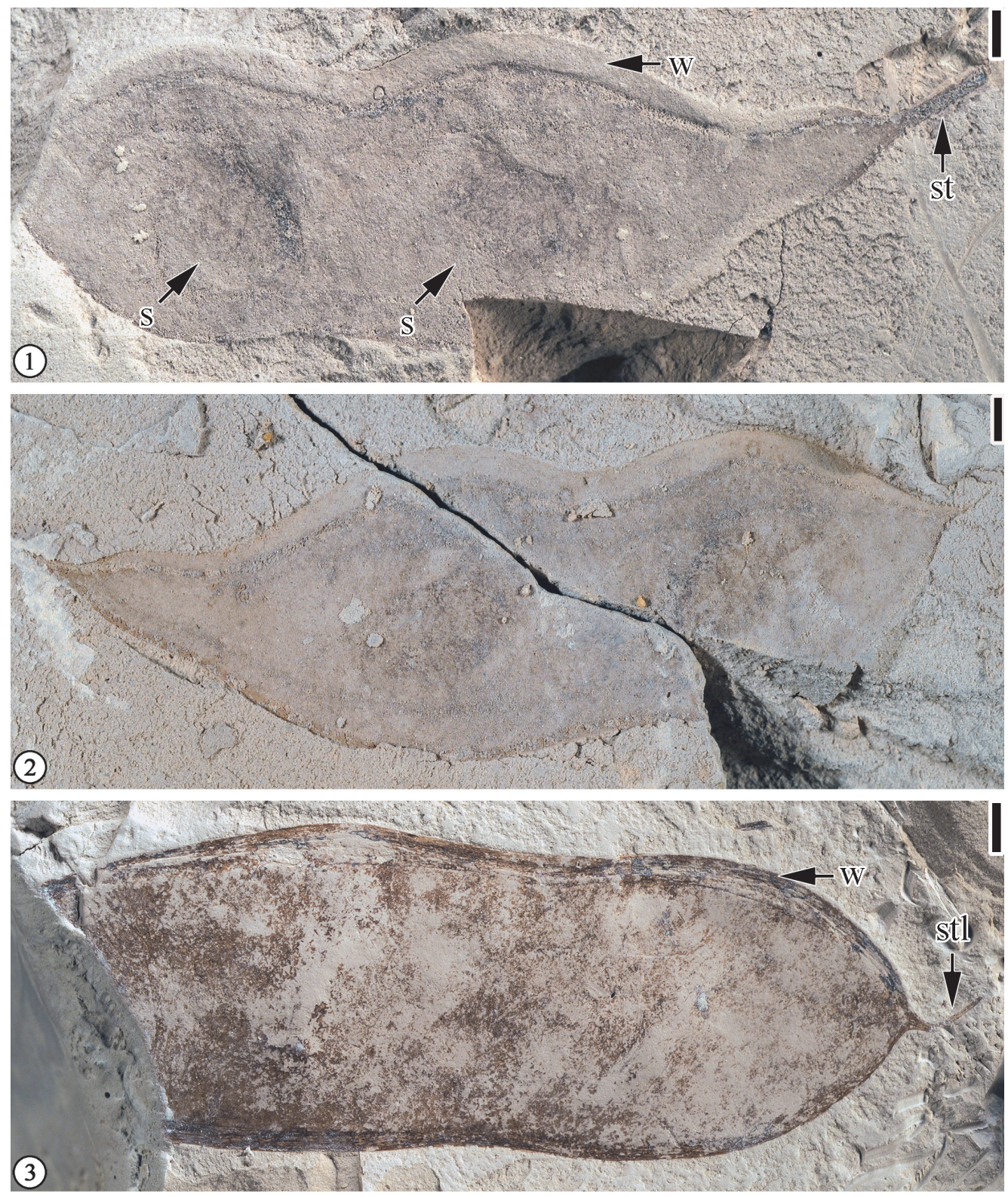

FIGURE 12. cf. Cladrastis sp.: 1) UF15820-005419, fruit with two parallel seeds (s), narrow wing (w) along placental suture, and stipe (st); 2) Counterpart of UF15820-005419; 3) UF15820-009012, fruit showing narrow wing (w) along placental suture, obtuse apex, and style (stl) on the right. All scale bars equal $2 \mathrm{~mm}$.

Remarks. This is the specimen illustrated by Herendeen (1992, p. 133, figures 244-245). The thick suture of this fruit from Puryear is similar to the "Thick walled fruit" reported from the Warman clay pit, Tennessee (Herendeen, 1992, figures 239242; Wang et al., 2013, figure 14.4). They differ in that the Puryear fruit is larger, has oblique striations, a single constriction and no seed chambers.

Claiborne Fabaceae Fruit Type 1

Figures 16, 17
Description. Compressed two-winged fruit, ca. 2.1 $\mathrm{cm}$ long and $2.5 \mathrm{~cm}$ wide (including wing); large wing ca. $6 \mathrm{~mm}$ wide, circumscribing two-thirds of the fruit body; reticulate veins forming at least three series of loops near the wing margin; small wing 3 $\mathrm{mm}$ wide, circumscribing one-third of the fruit body. Fruit body ca. $1.4 \mathrm{~cm}$ in diameter, covered with ca. $3 \mathrm{~mm}$ long spines. Pedicel ca. $23 \mathrm{~mm}$ long and 1 $\mathrm{mm}$ wide. 

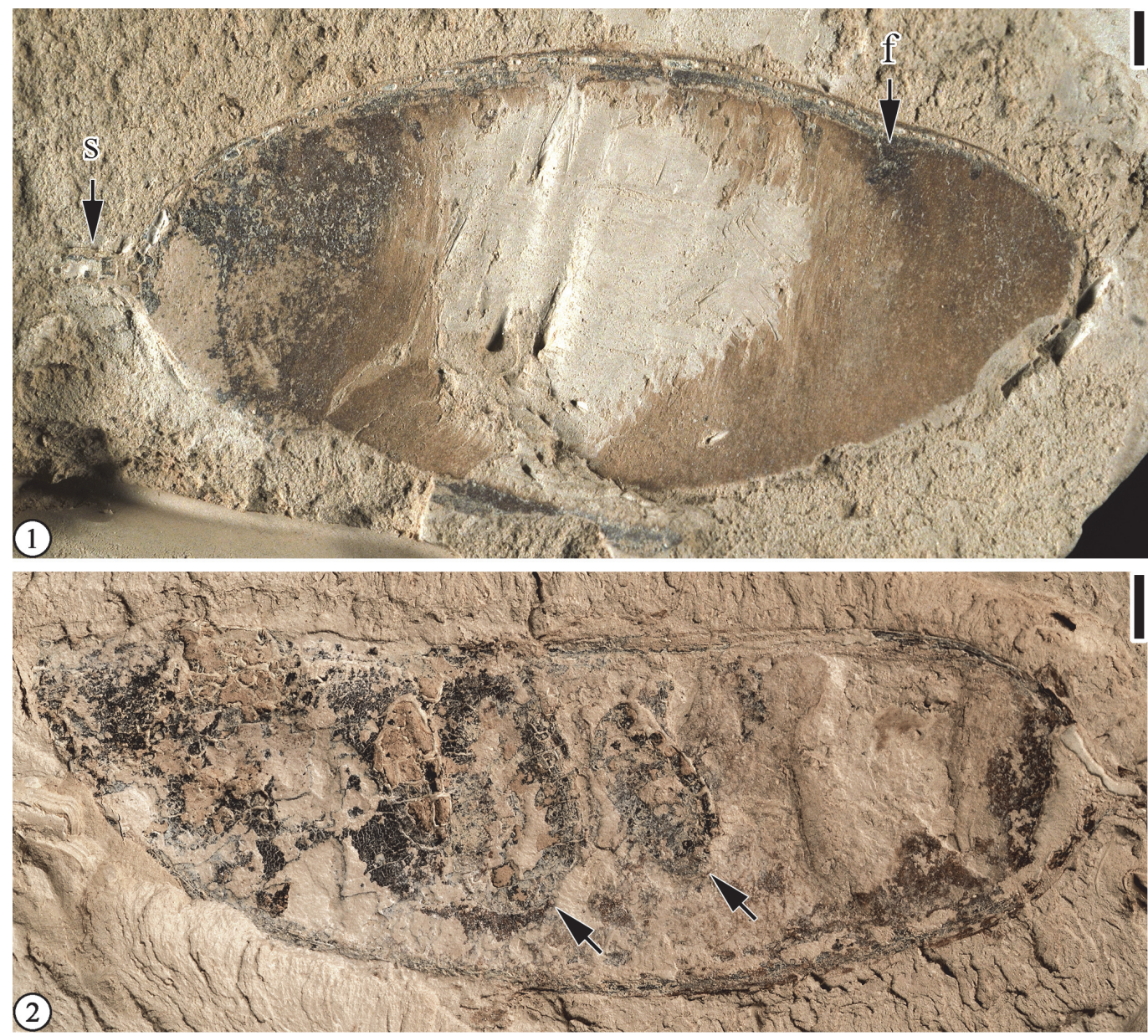

FIGURE 13. "Fruits similar to the Sophoreae" 1) UF15820-005847, fruit showing obtuse apex on the right and rounded base with stipe (s) on the left, and funiculus (f); 2) UF15820-000025a, fruit showing outlines of ovules (indicated by arrows), and rounded base with stipe on the right. All scale bars equal $2 \mathrm{~mm}$.

Number of specimens examined. 3. UF15820061134, 059396; CONN-R03-01.

Remarks. The venation pattern of the large wing of this fruit type is similar to that of Paleooreomunnea stoneana Dilcher, Potter and Crepet (Berry 1930, p. 60 , pl. 46, figures 11, 12; Dilcher et al., 1976, p. 539, figures 26-32; Manchester, 1987, p. 59, figure 28E-L; Wang et al., 2013, p. 23-24, figure 19). However, they differ in that the wing of this fruit type is not lobed, lacks prominent major vein(s) and peltate scales, and the fruit body is covered with spines. The typical bilobed nut, tri-lobed wing, and persistent style and sepals of $P$. stoneana are not observed. Based on the length of the second wing of this fruit type, it seems that it only covers a very small portion of the nut, not as much as $2 / 3$ of the nut as illustrated by Dilcher et al. (1976) and Manchester (1987) for $P$. stoneana.
The presence of two wings or a single discshaped wing and an indumentum on the nutlet are not uncommon in fossil and extant juglandaceous fruits. Nutlets of extant (e.g., Engelhardia serrata and Engelhardia spicata; Lu et al., 1999) and fossil fruits such as Palaeocarya hispida Meng and Zhou (Meng et al., 2015) and Palaeocarya mississippiensis (Berry) Manchester (Manchester, 1987) are covered by trichomes/spines.

Similar winged fruits also occur in some extant members of Fabaceae, i.e., Pterocarpus and Riedeliella. Both genera were recently assigned to the monophyletic Pterocarpus clade within the Dalbergieae (Cardoso et al., 2013). Pterocarpus is a pantropical genus with 72 accepted species (The Plant List; http://www.theplantlist.org). Some species, including Pterocarpus angolensis De Candolle, Pterocarpus echinatus Persoon, Pterocarpus erinaceus Poiret, and Pterocarpus indicus Willdenow 

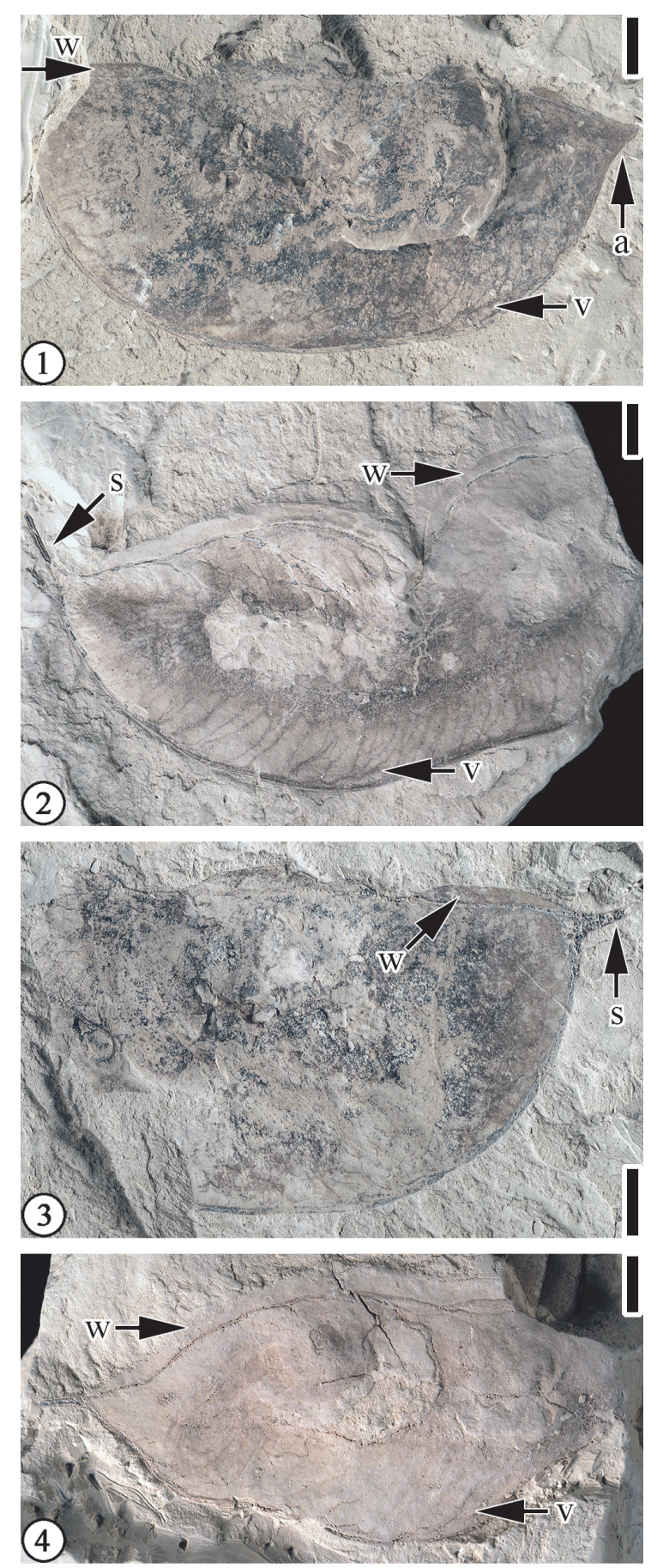

FIGURE 14. "Short, broad winged fruit" 1) UF15820007696, fruit showing acuminate apex (a), wing (w) along placental suture, and valve venation (v); 2) UF15820-007679, fruit showing stipe (s), wing (w) along placental suture, and valve venation (v); 3) UF15820005834, fruit showing stipe (s) and wing (w) along placental suture; 4) UF15820-007082, fruit showing wing (w) along placental suture and valve venation (v). All scale bars equal $5 \mathrm{~mm}$. have winged fruits with bristles on the fruit body and venation patterns similar to the Puryear specimens on the wing. Based upon these similarities, we tentatively assign these Puryear specimens to a fruit type in the Fabaceae.

Order ROSALES von Berchtold and J. Presl, 1820

Family CANNABACEAE Martynov, 1820

Genus PTEROCELTIS Maximowicz, 1873

Pteroceltis knowltonii (Berry) Manchester, Chen, Lu and Uemura, 2009

Figure 18

1916 Dodonaea knowltoni Berry 1916, p. 271, pl. 64, fig. 3.

Description. Fruit broadly winged, consisting of a central, asymmetric, globose endocarp, and two wings with radiating striations; overall fruit size (including wings) $1.5-2 \mathrm{~cm}$ long and $2-2.3 \mathrm{~cm}$ wide; endocarp ca. $5 \mathrm{~mm}$ in diameter; two wings of different sizes, with small wing 3-5 $\mathrm{mm}$ wide and large wing 5-7.5 mm wide (measured in the direction parallel to striations). Styles two, persistent. Stipe short, $2 \mathrm{~mm}$ long and $0.5 \mathrm{~mm}$ wide.

Number of specimens examined. 6. UF15820029089, 055902, 055903, 055904, 059206, 059397.

Remarks. The genus Pteroceltis has only one extant species, Pteroceltis tatarinowii Maximowicz. This species is a tree of temperate regions of northern to south-central China and Mongolia. Modern Pteroceltis fruits consist of a globose endocarp, two finely striate lateral wings, and persistent perianth and style (Fu et al., 2003; Manchester et al., 2009). The characters of the six Puryear specimens are consistent with those of the modern fruits except that pedicels and persistent perianth are not observed.

Berry (1916b; p. 271, pl. 64, figure 3) described a fruit from the Puryear clay pit, Tennessee, and assigned this specimen to Dodonaea knowltoni. Manchester et al. (2009, p. 18, figure 17) emended it to Pteroceltis knowltonii. The specimen illustrated by Berry (1916b) shows a pedicel which does not show in the image of the same specimen in Manchester et al. (2009, p. 17, figure 17).

Pteroceltis fossil fruits have been described from the middle Eocene of Republic, Washington, USA (Pigg and Wehr, 2002), the late Oligocene of Germany (Manchester, 1989), and the Neogene of Korea and Japan (Oishi and Huzioka, 1942). However, Manchester et al. (2009) suggested that the Neogene records of this genus from Korea and Japan (Oishi and Huzioka, 1942) need to be reexamined to confirm or reject its assignment to Ptero- 


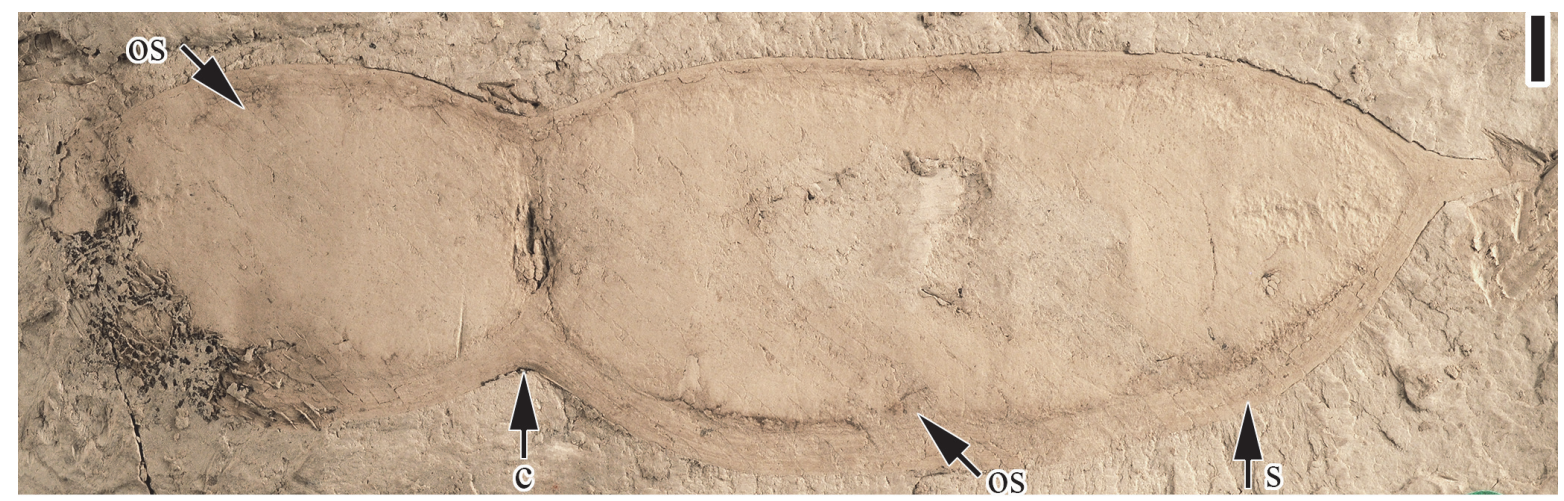

FIGURE 15. cf. Leguminosites ingafructoides Berry, 1930: UF15820-005843, fruit showing wide sutures (s), constriction (c) and vertical partition, and oblique striations (os) that are oriented parallel to the direction of the arrows. Scale bar equals $5 \mathrm{~mm}$.

celtis (Manchester et al., 2009). Other reports of this genus are based on leaves from Tennessee, USA (Berry 1916b, p. 270, pl. 38, figure 2) and the Miocene of China (Sun et al., 1999, pl. 6, figure 4).

Family ULMACEAE Mirbel 1815

Genus EOCELTIS Zavada and Crepet, 1981

Eoceltis dilcheri Zavada and Crepet, 1981

Figure 19

Description. Flowers up to $9 \mathrm{~mm}$ in diameter with perianth composed of four whorled tepals. Staminate flowers having up to 15 stamens with elongate anthers. Pollen triporate with lolongulate pores. Exine finely scabrate and perforate. Exine $1 \mu \mathrm{m}$ in thickness, somewhat intermediate between granular and columellar, and occasionally with invaginations of the tectum (Zavada and Crepet, 1981, p. 931, figs. 7-13).

Number of specimens examined. 2. UF15816001356, 000455.

Remarks. Zavada and Crepet (1981) described seven specimens from the Lawrence clay pit and one specimen from the Puryear clay pit. Geographically, these two localities are 28 kilometers apart and chronostratigraphically, the Puryear locality is slightly older than the Lawrence locality (Table 2). We are unable to locate the Puryear specimen reported by Zavada and Crepet (1981), which was presumably collected by David Dilcher and should be stored at the Florida Museum of Natural History. Two specimens, including the holotype, from the Lawrence clay pit are illustrated here to demonstrate the characters of this species.

Based upon floral and pollen features, including unisexuality of flowers, four tepaloid perianth parts in a whorl, type of pubescence, pollen type, and exine structures, Zavada and Crepet (1981) suggested that these flowers are related to the subfamily Celtidoideae of the Ulmaceae. When the stratification of exine of the fossil pollen is compared with that of the modern Celtis pollen, the alliance of the fossil with the Celtidoideae is apparent. Both have tectum perforated by more or less regular narrow channels and the same tectum thickness. However, they differ notably in that (1) the exine of the fossil pollen is closer to the truly tectate-columellate structure; (2) it has the greater number of columellae; (2) the columellae are formed by the fusion of granules; and (4) and the fossil pollen has invaginations in the tectum. The presence of invaginations in the tectum is only observed in the pollen of the Tiliaceae and the Dipterocarpaceae.

We agree with Zavada and Crepet (1981) and assign these fossil flowers to the Ulmaceae.

Order FAGALES Engler, 1892

Family FAGACEAE Dumortier, 1829

Genus CASTANOPSOIDEA Crepet and Nixon, 1989

Castanopsoidea columbiana Crepet and Nixon 1989

Figure 20

Description. Laterally preserved, unbranched infructescences bearing ovate, alternately arranged, sessile, cupules ca. 7-8 mm long and 3$3.5 \mathrm{~mm}$ wide; axis ca. $3-3.5 \mathrm{~cm}$ long and $1.5-2$ $\mathrm{mm}$ wide. The cupule covered by overlapping linear, transversely arranged scales with acute apices. Dispersed fruit sessile, triangular, ca. $5 \mathrm{~mm}$ long and $5 \mathrm{~mm}$ wide.

Number of specimens examined. 3. UF15820059490a, 061131, 059483. 

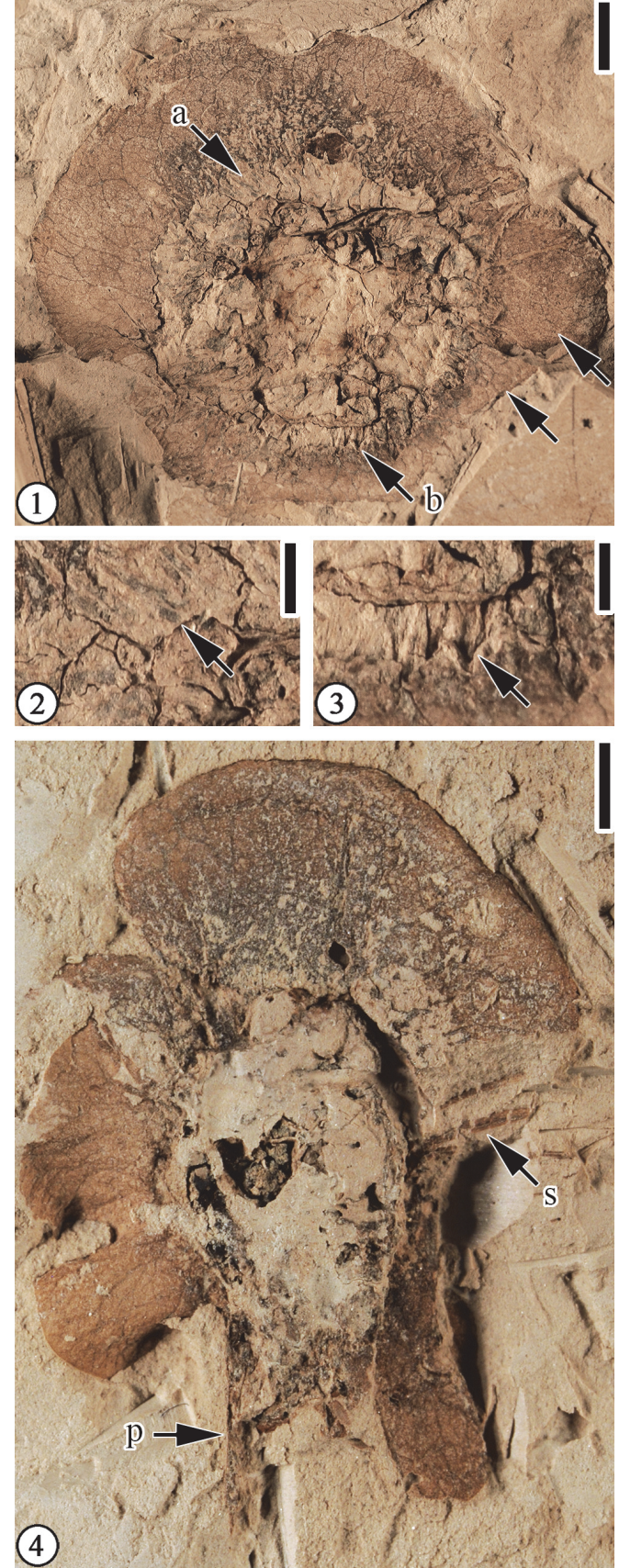

FIGURE 16. Claiborne Fabaceae Fruit Type 1: 1) UF15820-061134, showing nutlet in the middle, large wing at the top and small wing at the bottom. Arrows a and $b$ indicate areas to be enlarged to show spines on the nutlet. The other two arrows on the right indicate that the two wings are on different levels with clay infilling between them. Scale bar equals $3 \mathrm{~mm}$; 2) Enlargement of $a$ in Figure 16.1 to show spines. Scale bar equals $1 \mathrm{~mm}$; 3 ) Enlargement of $b$ in Figure 16.1 to show spines going underneath the small wing. Scale bar equals $1 \mathrm{~mm}$; 4) UF15820-059396, showing a pedicel (p) - or gynophore and spines (s). Scale bar equals $3 \mathrm{~mm}$.

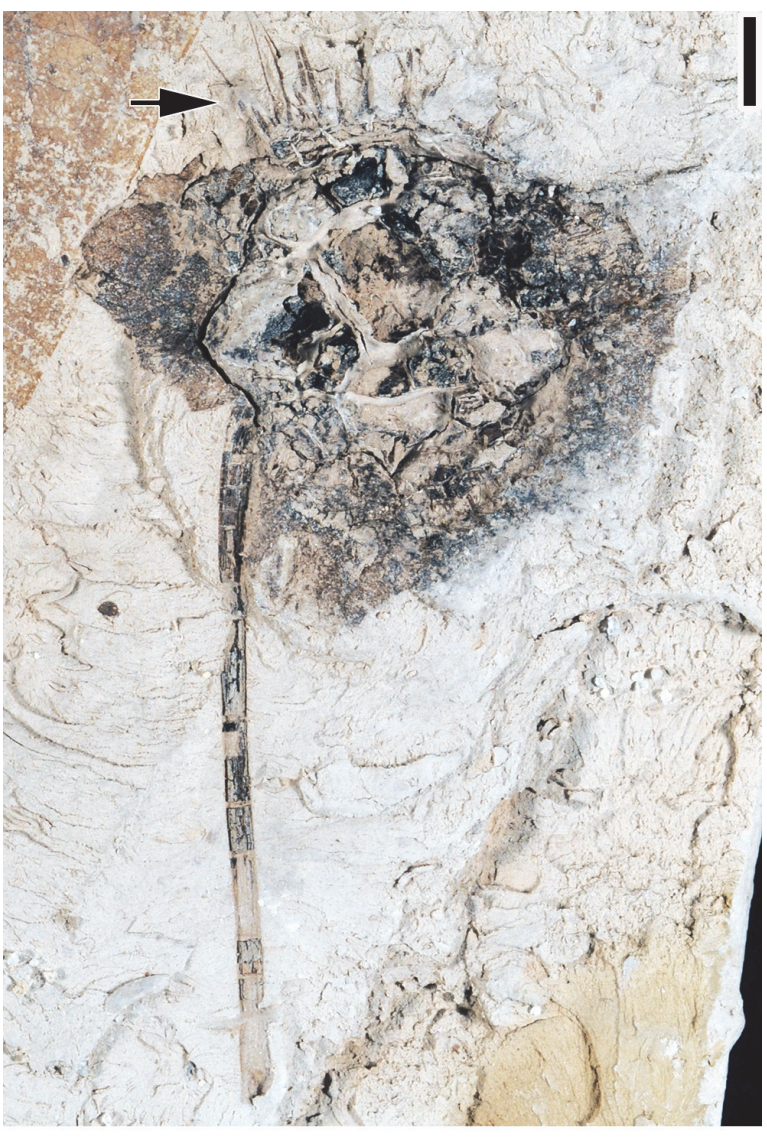

FIGURE 17. Claiborne Fabaceae Fruit Type 1: CONNR03-01, compressed fruit showing a long pedicel and spines (indicated by arrow). Scale bar equals $3 \mathrm{~mm}$.

Remarks. These specimens probably represent infructescences with mature cupules attached. The characters of the Puryear specimens, including infructescences with alternately arranged, sessile cupules that are covered by overlapping linear, transversely arranged scales, and triangular fruits, are consistent with those described by Crepet and Nixon (1989, figs. 11-12, 16-23) from the Buchanan locality (Table 2), except that the cupules of the Puryear specimens have better preserved elongate external scales with hairs and that the detached fruits of the Puryear specimens do not show well-preserved fruit wings and styles. Crepet and Nixon (1989, p. 847) suggested that the spines on the cupule developed late and elongated considerably during maturation. The lack of fruit wings and styles of the detached fruits from the Puryear locality may be the result of transportation before deposition and/or preservation.

Genus CASTANEOIDEA Crepet and Daghlian, 1980 

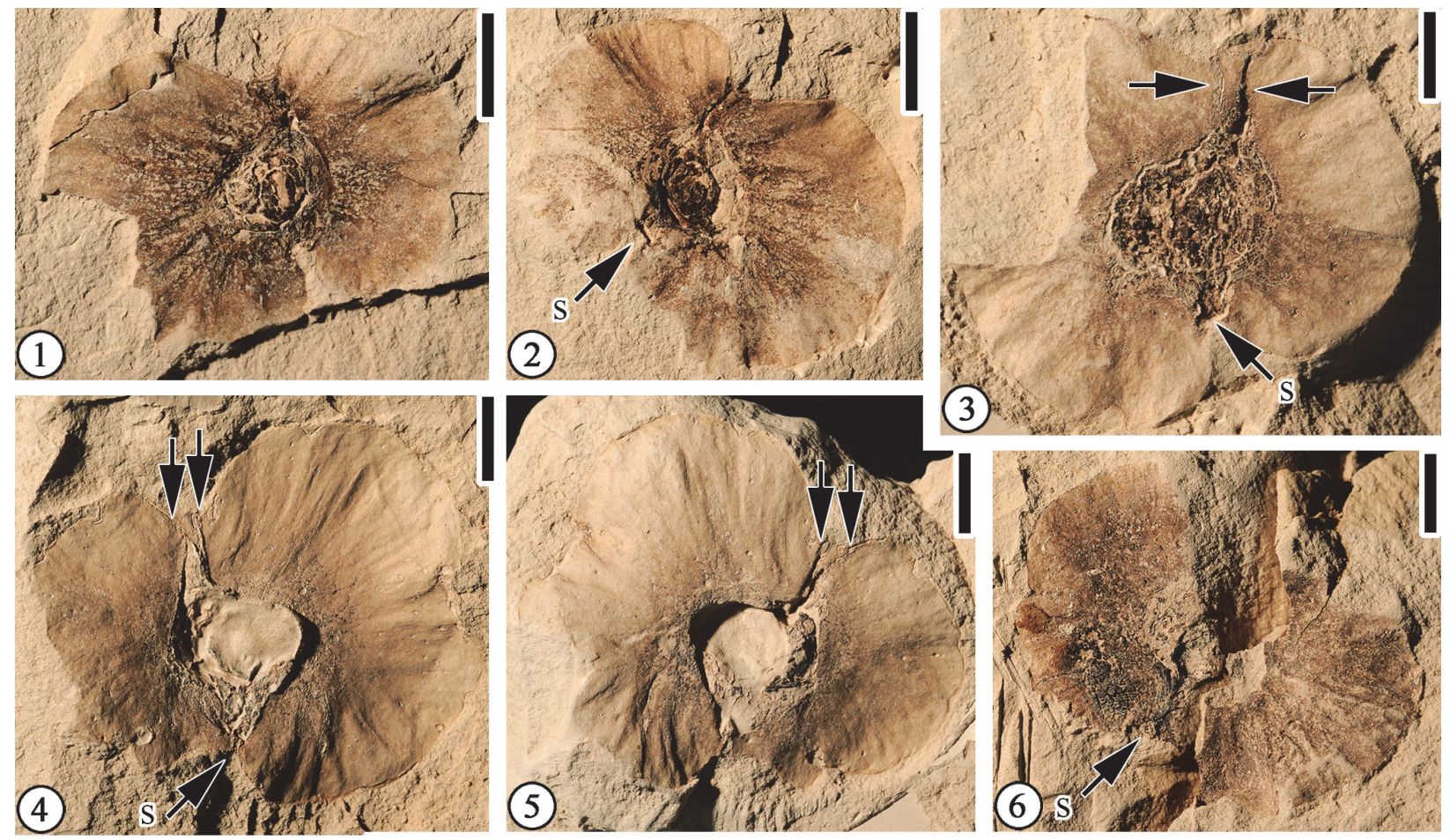

FIGURE 18. Pteroceltis knowltonii (Berry) Manchester, Chen, Lu and Uemura, 2009: 1-2) UF15820-029089, 029089', part and counterpart of specimen showing the short stipe (s). Scale bar equals $5 \mathrm{~mm}$; 3) UF15820-055903, specimen showing cordate base, stipe (s) at the base, two styles at the distal end (indicated by arrows), and asymmetric fruit body and wings of different sizes. Scale bar equals $3 \mathrm{~mm}$; 4-5) UF15820-055902, 055902', part and counterpart of specimen showing stipe (s) at the base and two styles at the distal end (indicated by the arrows). Scale bar equals 4 $\mathrm{mm}$; 6) UF15820-059397, specimen showing stipe (s). Scale bar equals $4 \mathrm{~mm}$.

\section{Castaneoidea puryearensis Crepet and Daghlian, 1980}

Generic and specific diagnosis. "Staminate catkins up to at least $90 \mathrm{~mm}$ in length having helically arranged, bract subtended, dichasia of three florets each. Florets have minute floral envelopes $(0.8$ $\mathrm{mm} \times 1.0 \mathrm{~mm}$ ) terminating in at least five ovate lobes. Floral envelope cuticle with rectangular epidermal cells, sometimes in rows, and with round trichome bases. Trichomes short hairs attached singly or in fascicles of at least two. Florets with up to ten stamens; anthers elliptical and small (length $0.24 \mathrm{~mm}$ ). Pollen tricolporate; $15.6 \mu \mathrm{m} \times 9 \mu \mathrm{m}$; exine ornamentation striate" (Crepet and Daghlian, 1980, p. 753).

Number of specimens examined. None (see discussion below).

Remarks. Crepet and Daghlian (1980, p. 753, figures 27-30) established a genus and species, Castaneoidea puryearensis, based on one specimen of a staminate inflorescence axis from the Puryear locality. We were unable to locate the holotype specimen (UCPC P36; Crepet and Daghlian, 1980, p. 753) during a visit to the University of
Connecticut herbarium in 2018. Here, we include the description of this specimen by Crepet and Daghlian (1980) to indicate the occurrence of this species at the Puryear locality.

\section{Genus TRIGONOBALANOIDEA Crepet and Nixon, 1989 \\ cf. Trigonobalanoidea americana Crepet and Nixon, 1989 \\ Figure 21}

Description. Incomplete laterally preserved unbranched axis with seven fruits attached; fruits orbicular, ca. $3.8 \mathrm{~mm}$ in diameter with three to four apical projections ca. $0.5 \mathrm{~mm}$ long, each with a longitudinal groove; axis ca. $2.8 \mathrm{~cm}$ long and $0.8 \mathrm{~mm}$ wide; pedicels ca. $1.5 \mathrm{~mm}$ long and $0.5 \mathrm{~mm}$ wide; persistent perianth parts present. No cupules or cupule scales are observed.

Number of specimens examined. 1. UF15820061130.

Remarks. This specimen probably represents a mature infructescence of Trigonobalanoidea americana (Crepet and Nixon, 1989). A major difference between the specimens from the Puryear and 

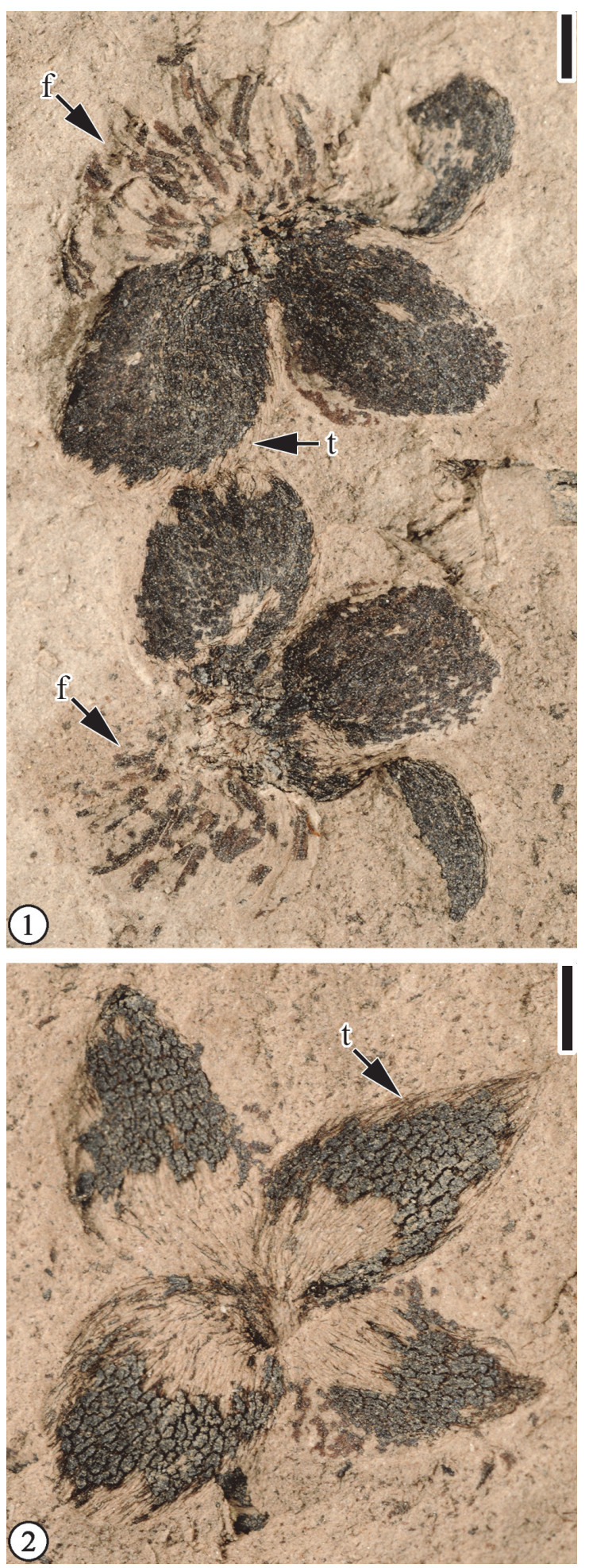

FIGURE 19. Eoceltis dilcheri Zavada and Crepet, 1981: 1) 15816-001356, specimen showing two flowers each with three tepals. Note filaments (f) and dense, simple trichomes (t). Scale bar equals $1 \mathrm{~mm}$; 2) UF15816000455 , showing a flower with four tepals covered with dense, simple trichomes (t). Scale bar equals $1 \mathrm{~mm}$.
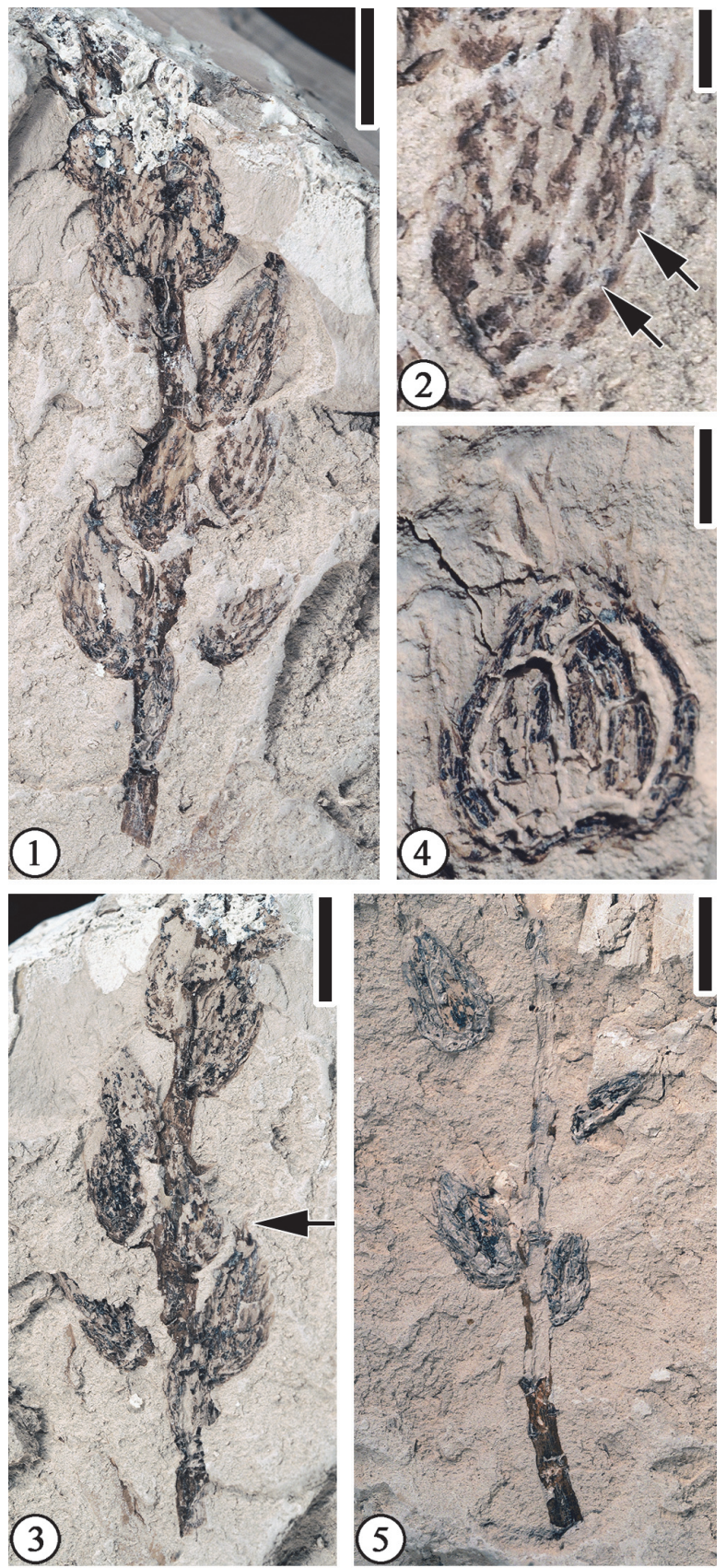

FIGURE 20. Castanopsoidea columbiana Crepet and Nixon, 1989: 1) UF15820-061131, showing an incomplete, unbranched infructescence. Scale bar equals 5 $\mathrm{mm}$; 2) Enlargement of Figure 20.1 to show transversely arranged scales on the cupule (indicated by arrows). Scale bar equals $1 \mathrm{~mm}$; 3) UF15820-061131', counterpart specimen showing scales with acute apices. Scale bar equals $5 \mathrm{~mm}$; 4) UF15820-059483, showing a sessile fruit with spiny scales. Scale bar equals $2 \mathrm{~mm}$; 5 ) UF15820-059490a, proximal portion of an incomplete infructescence showing four cupules. Note one cupule is detached. Scale bar equals $5 \mathrm{~mm}$. 

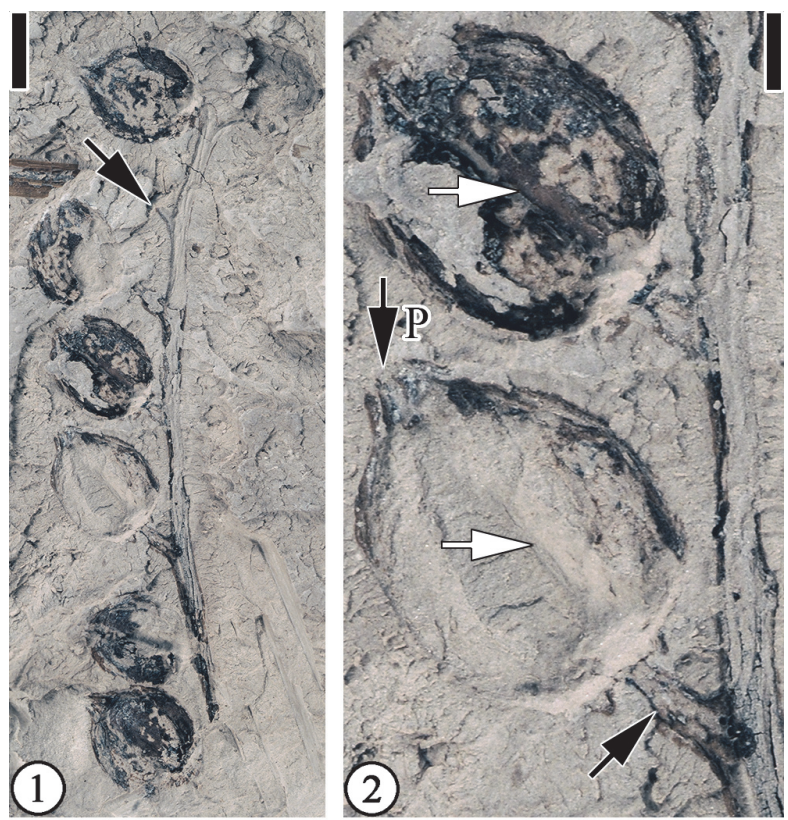

FIGURE 21. cf. Trigonobalanoidea americana Crepet and Nixon, 1989: 1) UF15820-061130, showing an infructescence with seven attached fruits. Note that one fruit is missing but the pedicel (indicated by arrow) is attached to the axis. Scale bar equals $3 \mathrm{~mm}$; 2) Enlargement of Figure 21.1 to show two fruits. Note a central groove (indicated by two white arrows) and a short pedicel (indicated by bottom arrow), and persistent perianth parts (p). Scale bar equals $1 \mathrm{~mm}$.

Bovay localities (Blanchard et al., 2016, p. 15, figure 14) and those from the type locality (Buchanan, Tennessee; Crepet and Nixon, 1989) is that the Puryear and Bovay specimens lack the fruit wings described by Crepet and Nixon (1989). Our Puryear specimen shows fruits with pedicels but lacking cupules and cupule scales.

\section{Claiborne Fagaceae Fruit Type 2}

Figure 22

Description. Cupulate fruits $3.5-5 \mathrm{~cm}$ long and 2.2-5 cm wide; cupule spiny; spines simple, apically curved, ca. $0.7-1.5 \mathrm{~cm}$ long, covered with simple trichomes; spines concentrically arranged on the cupule, area of cupule enclosing nut/nutlets $2.5-3.0 \mathrm{~cm}$ long and $2.0-2.5 \mathrm{~cm}$ wide. Attachment scar of the cupule $3 \mathrm{~mm}$ in diameter.

Number of specimens examined. 9. UF15820004016, 004016', 004020, 032202, 061121.

Remarks. Wang et al. (2013, p. 23, figure 16. 3) reported one specimen assignable to this morphotype from the Warman clay pit, Tennessee. The specimens from the Puryear locality provide more characters than the Warman specimen and war- rant a separate fruit type for these large cupulate fruits with simple spines.

It seems that cupules of this fruit type entirely enclose the fruits. The number of nuts that each cupule encloses is unknown. Vertically compressed cupules (Figure 22.3) show the width of the pedicels, but their length and how they are attached to the axis are unknown.

Based on the presence of unbranched, stout spines on the cupule that do not obscure its surface (see Figure 22.1; Nixon, 1997), this fruit type is probably closely related to the genus Fagus.

Table 3 lists the major characters of Claiborne Fagaceae Fruit Types 1 to 6 and Catahoulea grahamii, a fagaceous fruit from the Oligocene Catahoula Formation Huntsville, Texas, with similar morphology.

\section{Claiborne Fagaceae Fruit Type 5 Figure 23}

Description. Cupule $2-2.5 \mathrm{~cm}$ long and $1.8-2 \mathrm{~cm}$ wide (including spines); cupule valves at least two, spiny; basal portions of the spines intertwined, forming a web-like pattern with laminal tissues within the network. Distal portions of the spines simple or branched. Simple trichomes present on the spines and lamina tissue. Peduncle not observed. Nuts/Nutlets not observed.

Number of specimens examined. 3. UF15820004015, 004025, 032853.

Remarks. Wang et al. (2013, p. 26, figure 17.1-3) described one specimen from the Warman clay pit, Tennessee and included it in Claiborne Fagaceae Fruit Type 3. Blanchard et al. (2016, pp. 18-20, figure 15.5) assigned it to a new type, Claiborne Fagaceae Fruit Type 5, because of its large fruit size and its stout, relatively long peduncle (Table 3 ). One specimen (Figure 23.2) shows that the cupule has at least two valves, indicating that it probably has multiple nutlets.

The absence of the distal portions of the spines probably indicates that the Puryear specimens were transported some distance before being deposited and preserved.

\section{Claiborne Fagaceae Fruit Type 6 Figure 24}

Description. Cupulate fruits $19-23 \mathrm{~mm}$ long and 17-20 mm wide; nutlet spiny, 11-15 mm long and 4-15 mm wide (excluding spines); spines simple, straight or curved, ca. $3-4 \mathrm{~mm}$ long and 0.2-0.3 $\mathrm{mm}$ wide.

Number of specimens examined. 3. UF15820$004019,059411$. 

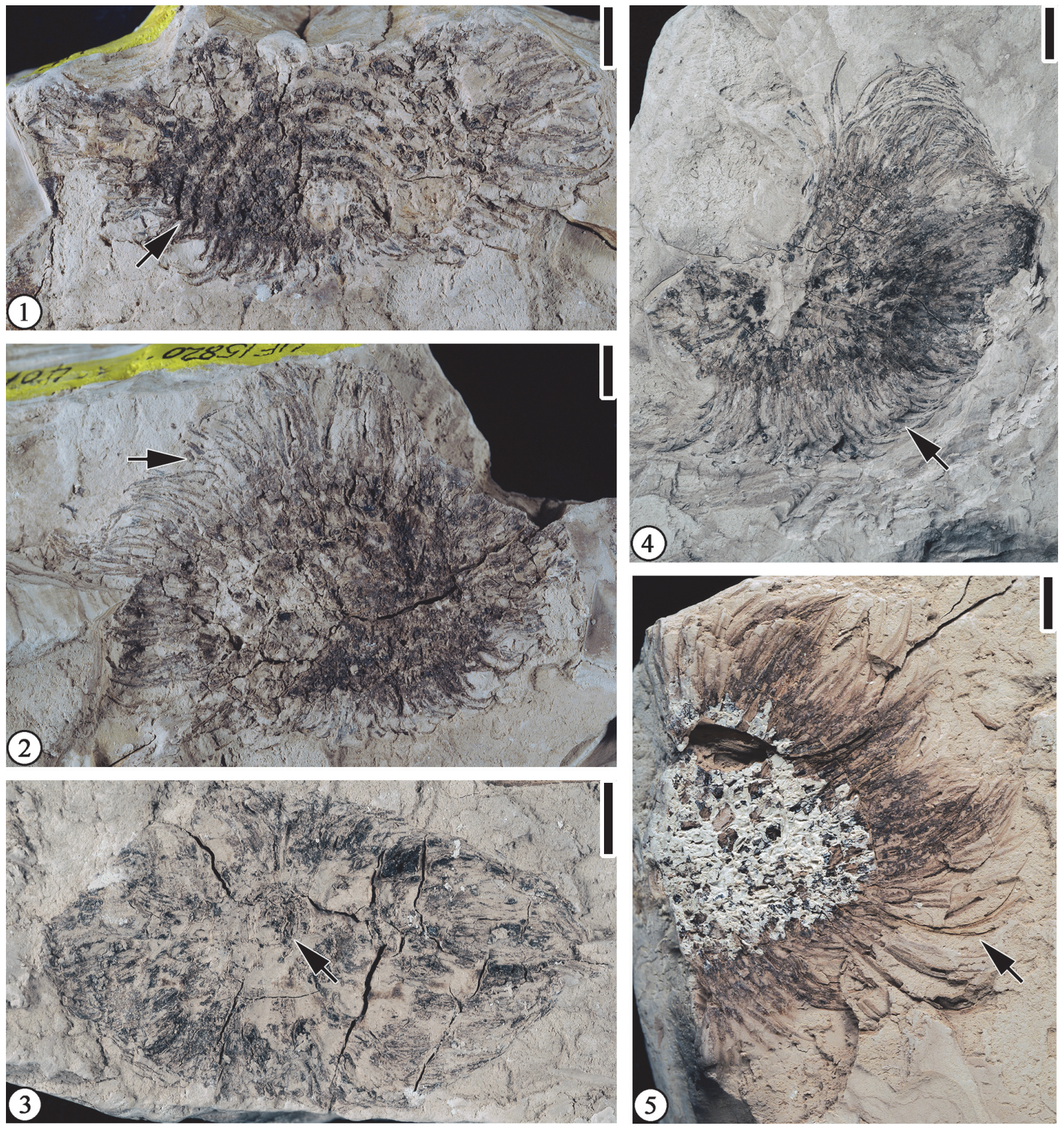

FIGURE 22. Claiborne Fagaceae Fruit Type 2: 1) UF15820-004016, base of cupule showing concentric arrangement of spines (indicated by arrow). Note at least six concentric circles; 2) UF15820-004016', note simple spines (indicated by arrow); 3) UF15820-004020, base of cupule showing attachment scar (indicated by arrow) and apically curved spines; 4) UF15820-061121, showing curved spines (indicated by arrow); 5) UF15820-032202, a large fruit about 5 $\mathrm{cm}$ in diameter. Note curved, simple spines (indicated by arrow). All scale bars equal $5 \mathrm{~mm}$.

Remarks. This type differs from other Claiborne fagaceous fruits in having a relatively small number of short, straight to slightly curved spines and a smaller fruit size (Table 3). Figure 24.1 seems to show that at least three cupules are clustered and attached to an axis.
Mindell et al. (2007) established a fossil taxon, Cascadiacarpa spinosa Mindell, Stockey and Beard, based on 80 anatomically preserved specimens of spiny, cupulate fruits from the Eocene Appian Way locality of Vancouver Island, British Columbia, Canada. The Puryear specimens and $C$. spinosa are similar in their small number of short, 

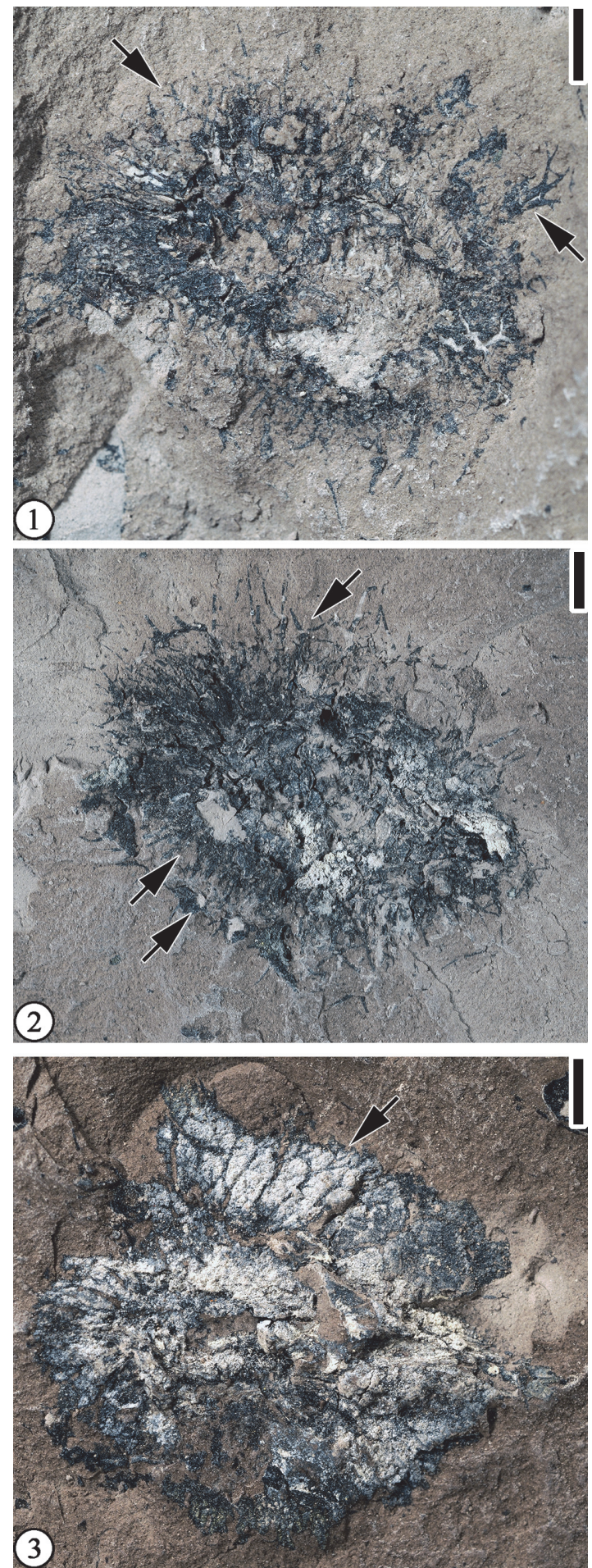

FIGURE 23. Claiborne Fagaceae Fruit Type 5: 1) UF15820-004015, fruit showing branched spines (indicated by arrows); 2) UF15820-004025, fruit showing two superimposed valves with clay filled in between them (indicated by lower left arrows) and branching and intertwining spines (indicated by top arrow); 3) UF15820032853, fruit showing valves with distal portions of spines missing and only proximal web-like valve preserved (indicated by arrow). All scale bars equal $3 \mathrm{~mm}$.
TABLE 3. Major characters of Claiborne Fagaceae Fruit Types 1 to 6 and Catahoulea grahamii. All dimensions are in millimeters. "?" indicates that a measurement is not available, or a character is not observed. Available as spreadsheet file for download at https://palaeo-electronica.org/content/2020/3177-fossil-plants-from-tennessee.

straight spines. They differ in that the spines of $C$. spinosa are branched and are often borne in clusters, and its spiny cupule encloses a single nut entirely with the exception of the apical stylar protrusion of the pistil.

Mindell et al. (2014) described another species, Cascadiacarpa exilis, from the Eocene Appian Way locality of Vancouver Island, British Columbia. These permineralized, fagaceous cupulate nuts are borne on a spiny stalk and are broadly
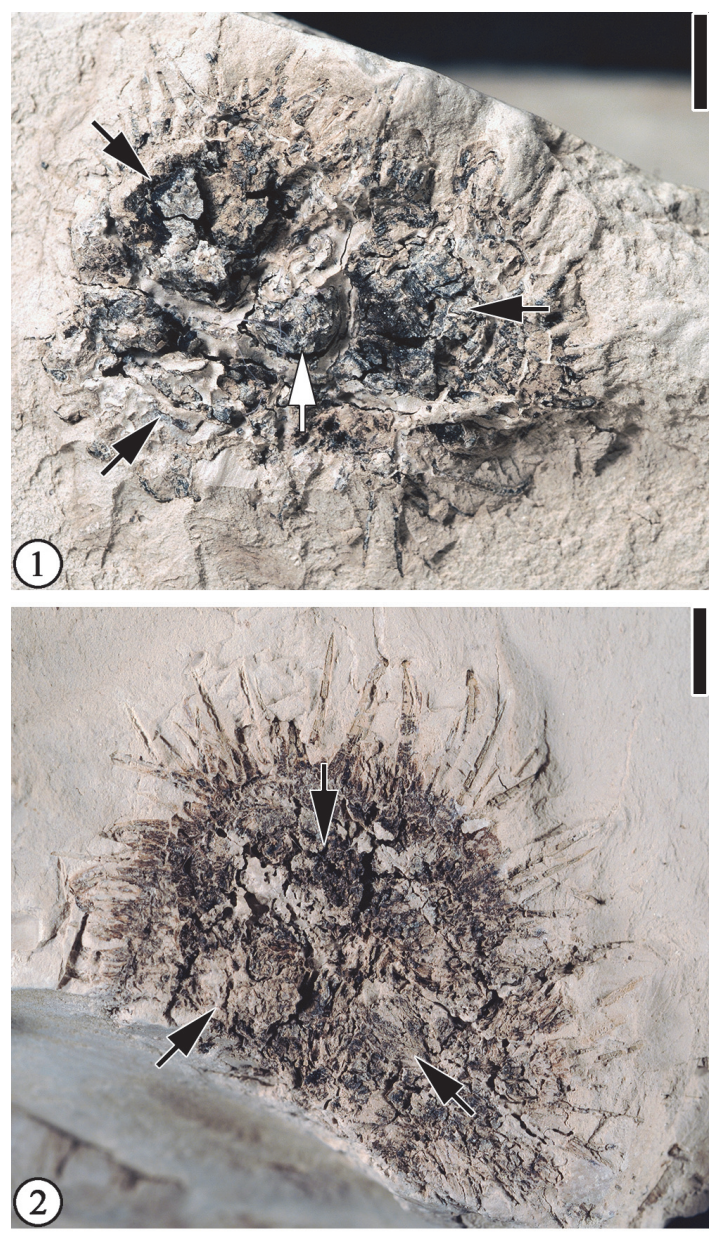

FIGURE 24. Claiborne Fagaceae Fruit Type 6: 1) UF15820-004019, fruit showing three cupules (cupule valves - indicated by black arrows) and axis (pedicel indicated by white arrow); 2) UF15820-059411, fruit showing three cupules (cupule valves - indicated by arrows) and simple spines. All scale bars equal $3 \mathrm{~mm}$. 
ovate in longitudinal and transverse section. The cupules are valvate and have both branching and simple spines. The cupule of $C$. exilis enclosed a single, ovoid, sclerotic nut entirely, except at the apex, where a stylar protrusion is free from any surrounding tissues. The two different modes of preservation (permineralized vs. compressed) make it difficult to compare these fossils, even though their sizes are similar and they both have simple spines.

\section{Family JUGLANDACEAE de Candolle ex Perleb, 1818 \\ Genus PALAEOCARYA \\ Palaeocarya puryearensis (Berry) Manchester, 1987}

Figure 25

1916 Engelhardtia puryearensis Berry, p. 185, pl. 17, figs. 6,7 .

1930 Engelhardtia puryearensis Berry, p. 60-62.

1976 Paraoreomunnea puryearensis (Berry) Dilcher, Potter and Crepet; Dilcher, Potter and Crepet, p. 536-537, figs. 7-15, 22, 23.

1987 Palaeocarya puryearensis (Berry) Manchester; Manchester, p. 45-53, figs. E-H.

Description. "Trilobate winged fruit with individual lobes conspicuous. Shape of central wing variable, oblanceolate or narrow elliptic; lateral wings narrow oblong, oblanceolate, or narrow elliptic. Wing apex may vary from obtuse to rounded, or sometimes from truncate to emarginate. Each lobe has a prominent midvein extending the length of the lobes with two prominent sub- ordinate lateral veins generally extending $2 / 3$ to $3 / 4$ the length of each lobe. The angle between the midveins of the lateral wings and central wing is variable $\left(50^{\circ}\right.$ to $\left.65^{\circ}\right)$. The central wing size ranges from $24-40 \mathrm{~mm}$ $x$ 5-10 $\mathrm{mm}$ and averages about $30 \mathrm{~mm}$ long $\times 8$ $\mathrm{mm}$ wide. The lateral wings range from $14-20 \mathrm{~mm}$ x 5-8 $\mathrm{mm}$ and average about $17 \mathrm{~mm}$ long x $6 \mathrm{~mm}$ wide. Conspicuous secondary veins extend at nearly right angles or arch slightly between the three primary veins in the central and lateral wings. Camptodromous secondary and tertiary veins are common between the lateral primary veins and the margin of the wings. The ultimate venation forms an intercostal mesh of closed veinlets. Fourth lobe of adaxial bract often not preserved but when preserved, the bract covers the nut and extends beyond it. It is fan shaped and about twice the size of the nut. The margin of the 4th lobe is somewhat lobate, and the venation consists of 6-8 primary veins radiating from the central basal area of the lobe. Flat arching secondary veins form numerous interconnections between the primary veins and the ultimate venation consists of a mesh of closed veinlets. The surface of all the lobes is often dotted with numerous discoid peltate glands. The nut is generally $5 \mathrm{~mm}$ in diameter and round to slightly prolate in outline. The fruit partitions are probably 8-celled (certainly 4-celled or more). Stigma, style, and sepals persist; sepals $1.75 \mathrm{~mm}$ long, style and stigma 1.75 long and probably with carinal orientation terminating in subglobose stigmatic area. Sepal lobes extend about the same length as the style and stigma, probably 4 sepal lobes present surrounding the style, standing erect or arching outward" (Dilcher et al., 1976, pp. 536-537).

Number of specimens examined. 6. UF15820001950, 002214, 002178, 002234, 004863, CONN-p410.

Remarks. Berry (1916b, 1930) first reported two specimens from the Puryear locality, Tennessee and assigned them to the extant genus, Engelhardia. Based on more specimens from the Puryear locality, Tennessee and the Lamkin locality, Kentucky, Dilcher et al. (1976) proposed a form name, Paraoreomunnea, because these fossils differ from extant Oreomunnea fruits in venation pattern (e.g., wing lobe prominently tri-veined and midrib of the each lobe extending directly to the apex in the fossil fruit rather than branching into smaller veins before reaching apex), in the presence of the $4^{\text {th }}$ lobe (prophyllum), in the nature of the sepals and styles (e.g., style with two long, curving stigmatic arms), and in the general shape. Manchester (1987) revised this to Palaeocarya puryearensis, because the older generic name, Palaeocarya (Saporta, 1873) has priority for these Oreomunnea-like fossil fruits.

\section{Genus EOENGELHARDIA Crepet, Daghlian and Zavada, 1980}

Type species. Eoengelhardia puryearensis Crepet, Daghlian and Zavada, 1980

Eoengelhardia puryearensis Crepet, Daghlian and Zavada, 1980

Description. "Staminate catkins $7 \mathrm{~cm}$ or more in length, axes $0.5-0.9 \mathrm{~cm}$ wide. Florets alternate, subtended by a three-lobed bract. Bract $2.1 \mathrm{~mm}$ in length, lobes sharply incised. Anthers small, 1.0 X $0.3 \mathrm{~mm}$, bilocular, with up to 9-12/floret. Pollen small, mean diam. $14.8 \mathrm{um}$, straight-sided triangular in polar view, rarely rounded-triangular, triporate, rarely tetraporate, exine finely scabrate, expore rounded-meridionally elongate" (Crepet et al., 1980, p. 367). 

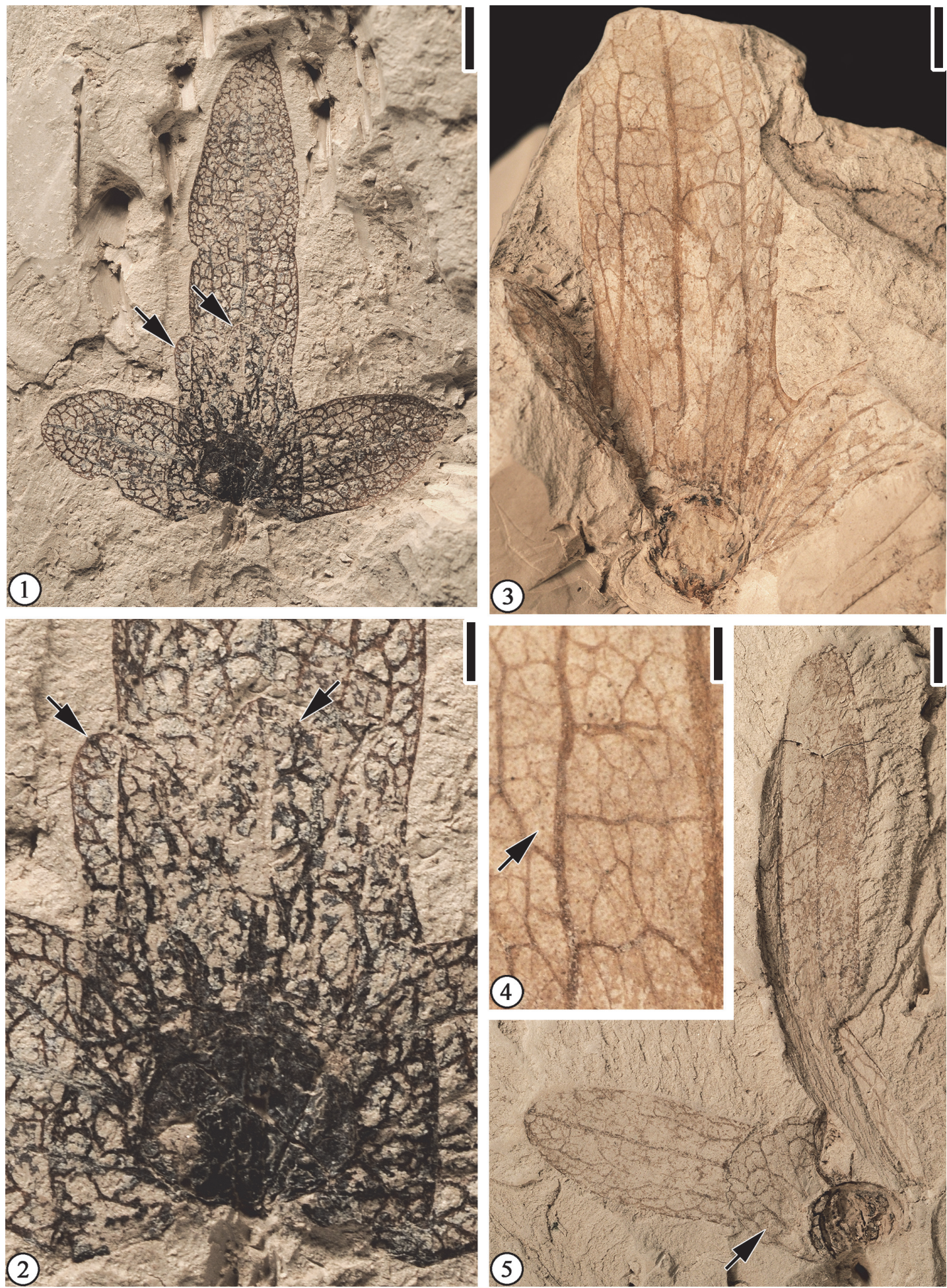

FIGURE 25. Palaeocarya puryearensis (Berry) Manchester, 1987: 1) 15820-00410 (CONN), showing trilobate fruit wing and bilobed prophyllum (indicated by arrows). Scale bar equals $3 \mathrm{~mm} ; 2$ ) Enlargement of Figure 25.1 to show bilobed prophyllum (indicated by arrows). Scale bar equals $1 \mathrm{~mm}$; 3) UF15820-001950, showing the central bract and poorly preserved lateral bracts. Scale bar equals $3 \mathrm{~mm}$; 4) Enlargement of the left portion of the central bract to show venation and trichomes (indicated by arrow). Scale bar equals $1 \mathrm{~mm}$; 5) UF15820-002214, showing the central bract and one lateral bract. Arrow indicates the prophyllum. Scale bar equals $3 \mathrm{~mm}$. 
Number of specimens examined. None from the Paleobotany Collection at the Florida Museum of Natural History.

Remarks. Eoengelhardia puryearensis Crepet, Daghlian and Zavada (Crepet et al., 1980) was established based on six staminate catkins from the Puryear locality, Tennessee. All specimens reported by Crepet et al. (1980) were reportedly stored at the University of Connecticut Paleobotany Collection (UCPC, now part of the Herbarium at the University of Connecticut, CONN). Unfortunately, an attempt by Wang on a visit to CONN to retrieve the specimens illustrated by Crepet et al. (1980) was not successful, possibly because these specimens are currently stored elsewhere.

This staminate catkin differs from Eokachyra aeolius Crepet, Dilcher, and Potter from the Warman clay pit, Tennessee (Crepet et al., 1975; Wang et al., 2013) in having smaller florets; a shorter, more radial, and more incised subtending bract; and smaller, more triangularly-shaped pollen grains (Crepet et al., 1980).

Genus PARAENGELHARDTIA Berry, 1916

Type species. Paraengelhardtia eocenica Berry, 1916

Paraengelhardtia eocenica Berry, 1916

Figure 26

1916 Paraengelhardtia eocenica Berry, p. 186, pl. 17, figs. 2-5.

1987 Paraengelhardtia eocenica Berry, Manchester, p. 57 , fig. 28A-D.

Description. "Winged nutlet with a small trilobed wing; sinuses between lobes of wing shallow to poorly developed, central lobe $16-23 \mathrm{~mm}$ long; lateral lobes diverging from central lobe at $25-40^{\circ}$, 14-19 mm long; width of fruit measured from outer margins of the two lateral lobes $19-31 \mathrm{~mm}$; each lobe supplied with a midrib and two slightly less prominent lateral veins, one on each side of the midvein; lateral giving rise to marginal tertiary loops and joined by secondary veins with the primaries; areoles supplied with numerous freely ending veinlets; prophyllum relatively large, rounded, 15-17 mm high, extending from the base of the nutlet two-thirds to four-fifths the length of the wing, six or more major veins fan out from the base of the prophyllum, looping within the margin; nutlet spheroidal, 4-5 mm diam., stylar configuration unknown; pedicel not observed to be persistent on fruit." (Manchester, 1987, p. 57)

Number of specimens examined. 4. UF15820004854; CONN-Q3-02.
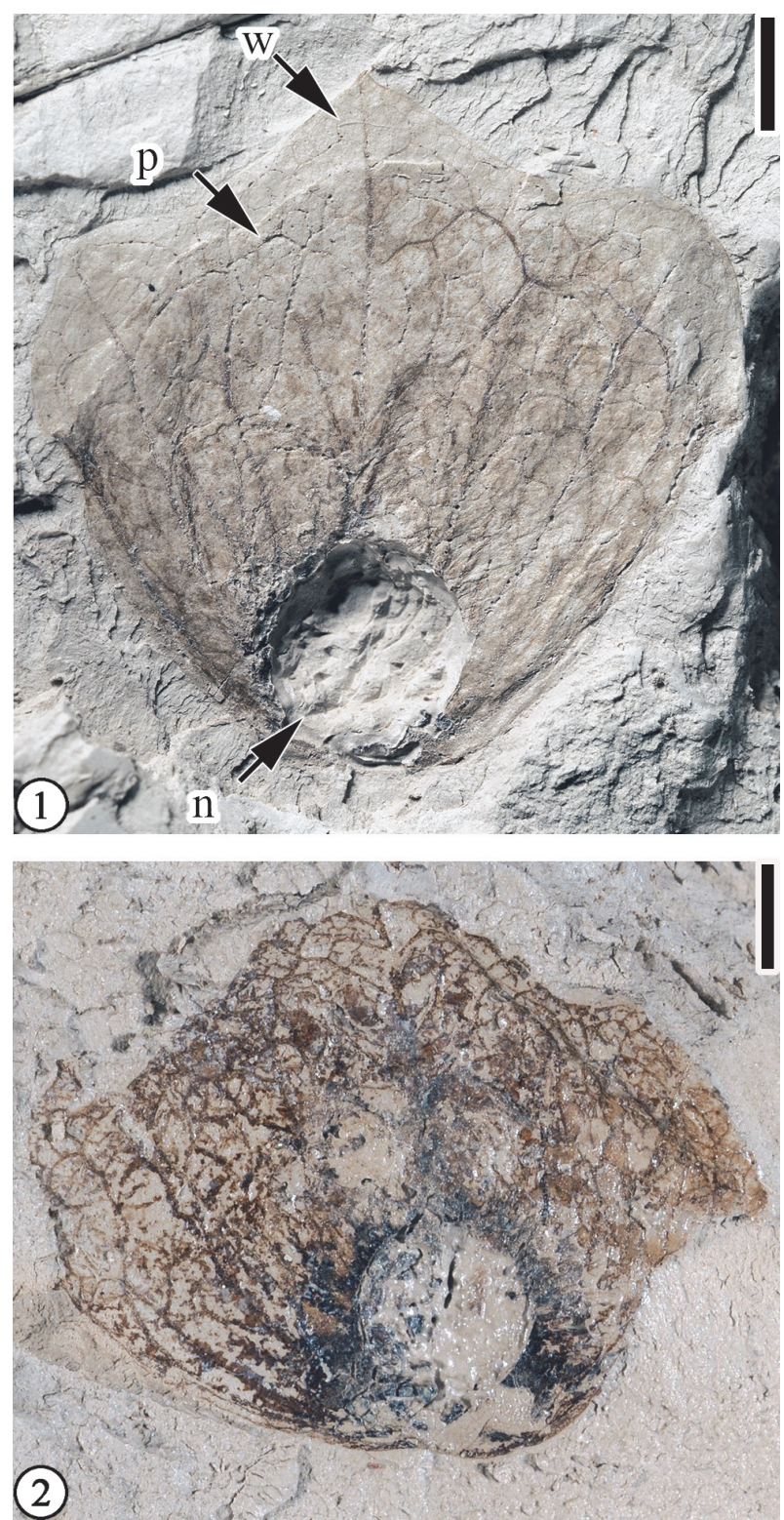

FIGURE 26. Paraengelhardtia eocenica Berry, 1916: 1) UF15820-004854, specimen showing a small nutlet (n) impression and the prophyllum ( $p$ ) extending almost four-fifths of the fruit wing (w). Scale bar equals $3 \mathrm{~mm}$; 2) CONN-Q3-02, compressed specimen showing nutlet and fruit wing. Scale bar equals $3 \mathrm{~mm}$.

Remarks. We illustrate one specimen reported by Manchester (1987, figure 28C) and one specimen from the CONN collection to demonstrate the characters of this species and its occurrence at the Puryear locality, Tennessee.

Berry (1916, p. 186, pl. 17, figures 2-5) established the fossil genus, Paraengelhardtia, and assigned four specimens from Puryear to the fossil 
species, P. eocenica. Manchester (1987, p. 57, figure 28A-D) illustrated four more specimens and noted that extensive collecting from the other Eocene clay pits of Kentucky and Tennessee has not yielded any specimens of this species.

This fossil species is similar to the extant fruits of Engelhardtia and Oreomunnea in nutlet size, and the presence of a trilobed wing and prophyllum. They differ in that the fossil fruit possesses shallow sinuses and short lobes.

Order MALPIGHIALES de Jussieu ex von

Berchtold and J. Presl, 1820

Family EUPHORBIACEAE de Jussieu, 1789

Genus CREPETOCARPON Dilcher and Manchester, 1988

Type species. Crepetocarpon perkinsii (Berry) Dilcher and Manchester, 1988

\section{Crepetocarpon perkinsii (Berry) Dilcher and Manchester, 1988}

Figure 27

1988 Crepetocarpon perkinsii (Berry) Dilcher and Manchester, figs. 1-10, 15-21, 24, 26-34, textfig. $1 \mathrm{~A}, \mathrm{~B}$; pp. $45-57$.

1922 Monocarpellites perkinsi Berry, pl. 16, fig. 1-6, p. 16.

Description. Vertically compressed fruit ca. $1.8 \mathrm{~cm}$ $x 1.4 \mathrm{~cm}$ (part) with eight radially arranged units around a ca. $2 \mathrm{~mm}$ diameter central column.

Number of specimens examined. 1. UF15820059480, 059480'.

Remarks. Dilcher and Manchester (1988) examined 75 specimens collected from the Richies Black (UF15828), Lawrence (UF15816), New Law-

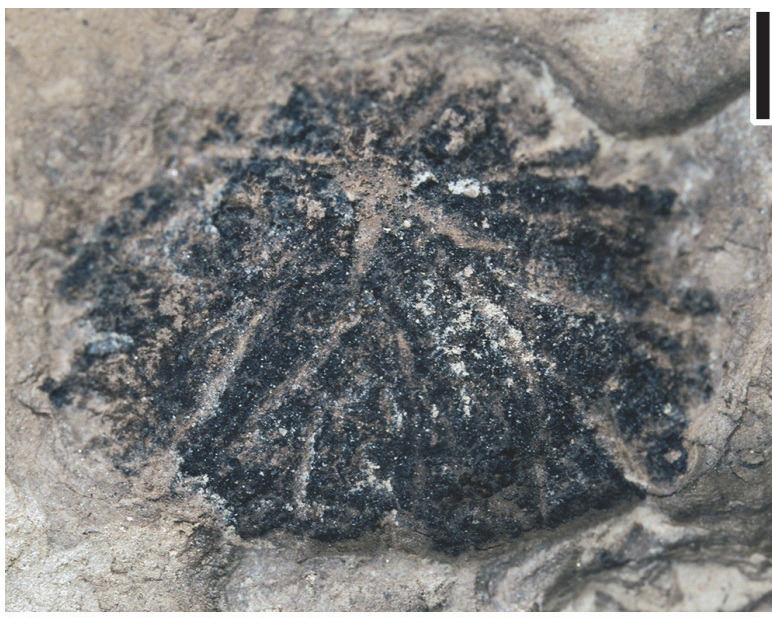

FIGURE 27. Crepetocarpon perkinsii (Berry) Dilcher and Manchester, 1988, UF15820-059480, compressed fruit with radiating ridges. Scale bar equals $2 \mathrm{~mm}$. rence (UF15818), and Miller (UF15817) localities in Henry Co., Tennessee, and two specimens reported by Berry (1922), also from Henry Co., Tennessee. Based on the striking similarities between the fruits of Crepetocarpon and extant Hippomane mancinella, they proposed that this fossil genus and species be assigned to the Euphorbiaceae (tribe Hippomaneae). These similarities include fruits consisting of comparable number of carpels, anatropous ovules, and each locule containing one seed embedded in a fibrous endocarp which is in turn covered by a mesocarp and an epidermal exocarp, They established the fossil genus because of major differences between the fossil and extant Hippomane fruits in margins of the endocarp rays (smooth vs. scalloped), mesocarp parenchyma cells (thick-walled vs. thin-walled), number of locules, fruit size, and tegmen thickness $(150 \mu \mathrm{m}$ vs. $25 \mu \mathrm{m})$.

Order SAXIFRAGALES von Berchtold and J. Presl, 1820

Family ALTINGIACEAE Lindley, 1846

Claiborne Altingiaceae Infructescence Type 1

Figure 28

Description. Pedunculate globose infructescence $1.1-2.1 \mathrm{~cm}$ in diameter. Peduncle at least $9 \mathrm{~mm}$ long and $1.5 \mathrm{~mm}$ wide with smooth surface. Fruits clustered together without obvious central receptacle cores exposed. No obvious styles observed on the distal ends of the fruits.

Number of specimens examined. 3. UF15820043600, 059407.

Remarks. This infructescence type, like those reported from the Warman clay pit (Wang et al., 2013, p. 11, figure 7), lacks persistent styles and stigmas. The lack of obvious persistent styles indicates that this infructescence type may be more closely related to the genus Altingia rather than Liquidambar since persistent styles and stigmas are typical features of mature infructescences of Liquidambar but are lacking in Altingia (Ickert-Bond et al., 2005, 2007).

\section{Genus LIQUIDAMBAR Linnaeus 1753 Liquidambar? sp. \\ Figure 29}

Description. Laterally compressed infructescence (fruit?) ca. $2 \mathrm{~cm}$ in diameter (including spike-like projections formed by the persistent styles).

Number of specimens examined. 1. CONN-Q1201.

Remarks. Dilcher and Lott (2005, p. 12, figure $18 \mathrm{D}, \mathrm{H})$ reported one specimen from the Powers clay pit, Tennessee, and assigned it to the extant 

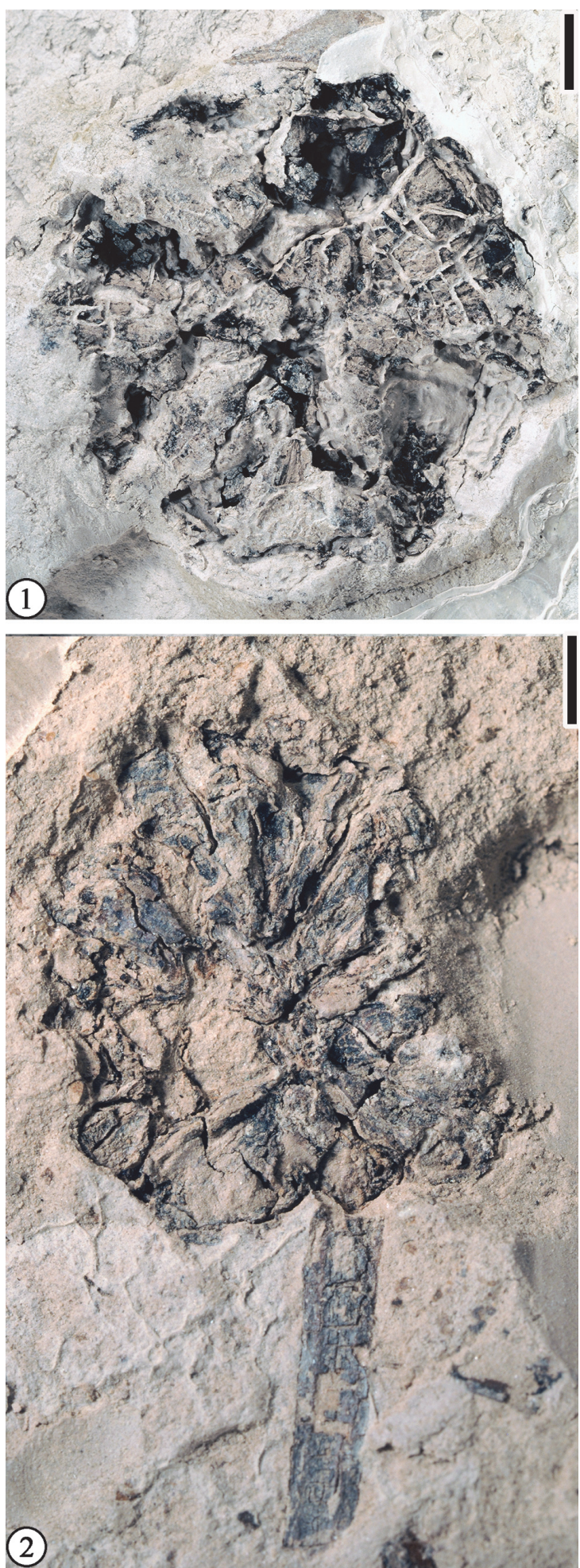

FIGURE 28. Claiborne Altingiaceae Infructescence Type 1: 1) UF15820-43600, infructescence with cluster of fruits. Scale bar equals $3 \mathrm{~mm}$; 2) UF15820-059407, infructescence with cluster of fruits and peduncle. Scale bar equals $2 \mathrm{~mm}$.

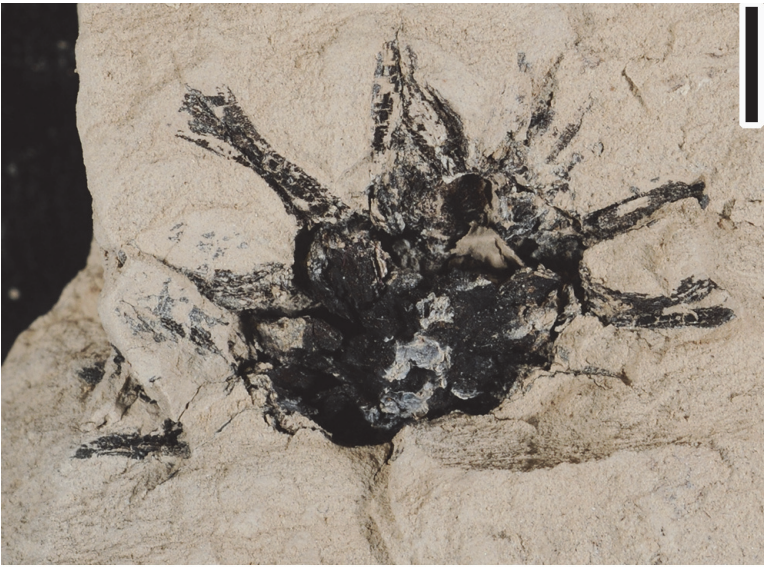

FIGURE 29. Liquidambar? sp.: CONN-Q12-01, laterally compressed infructescence with persistent styles. Scale bar equals $4 \mathrm{~mm}$.

genus Liquidambar. The persistent styles of the two specimens from the Puryear and Powers clay pits indicate that they may be related to Liquidambar. However, available morphological characters do not warrant the assignment of these specimens to the modern genus, even though pollen of Liquidambar has been reported from the Claiborne Group of Alabama (Gray, 1960). Based on previous phylogenetic analyses that show Altingia and Semiliquidambar are nested within Liquidambar, Ickert-Bond and Wen (2013) transferred all Altingia and Semiliquidambar species to Liquidambar and recognized 15 species within the genus.

Order ERICALES von Berchtold and J. Presl, 1820

Family THEACEAE Mirbel ex Ker Gawler, 1816

Genus ANDREWSIOCARPON Grote and Dilcher, 1989

Andrewsiocarpon puryearensis sp. nov. Figure 30

Diagnosis. Large, loculicidally dehiscent capsule containing five valves and winged seeds; a medial ridge and an apical beak present on each valve; one or two seeds per locule, each with an apical wing; seed wing membranous with no apparent veins. A central columella present. Pedicel stout.

Description. Large, loculicidally dehiscent capsule containing five valves and winged seeds; a medial ridge and an apical beak present on each valve; valve ca. $25-30 \mathrm{~mm}$ long and $9 \mathrm{~mm}$ wide; apical beak ca. $3 \mathrm{~mm}$ long and $1 \mathrm{~mm}$ wide; one or two seeds per locule, ca. $20 \mathrm{~mm}$ long and $5 \mathrm{~mm}$ wide, each with an apical wing; seed wing membranous with no apparent veins. A central columella present, ca. $20 \mathrm{~mm}$ long and $5 \mathrm{~mm}$ wide. Pedicel stout, ca. $8 \mathrm{~mm}$ long and $4 \mathrm{~mm}$ wide. 


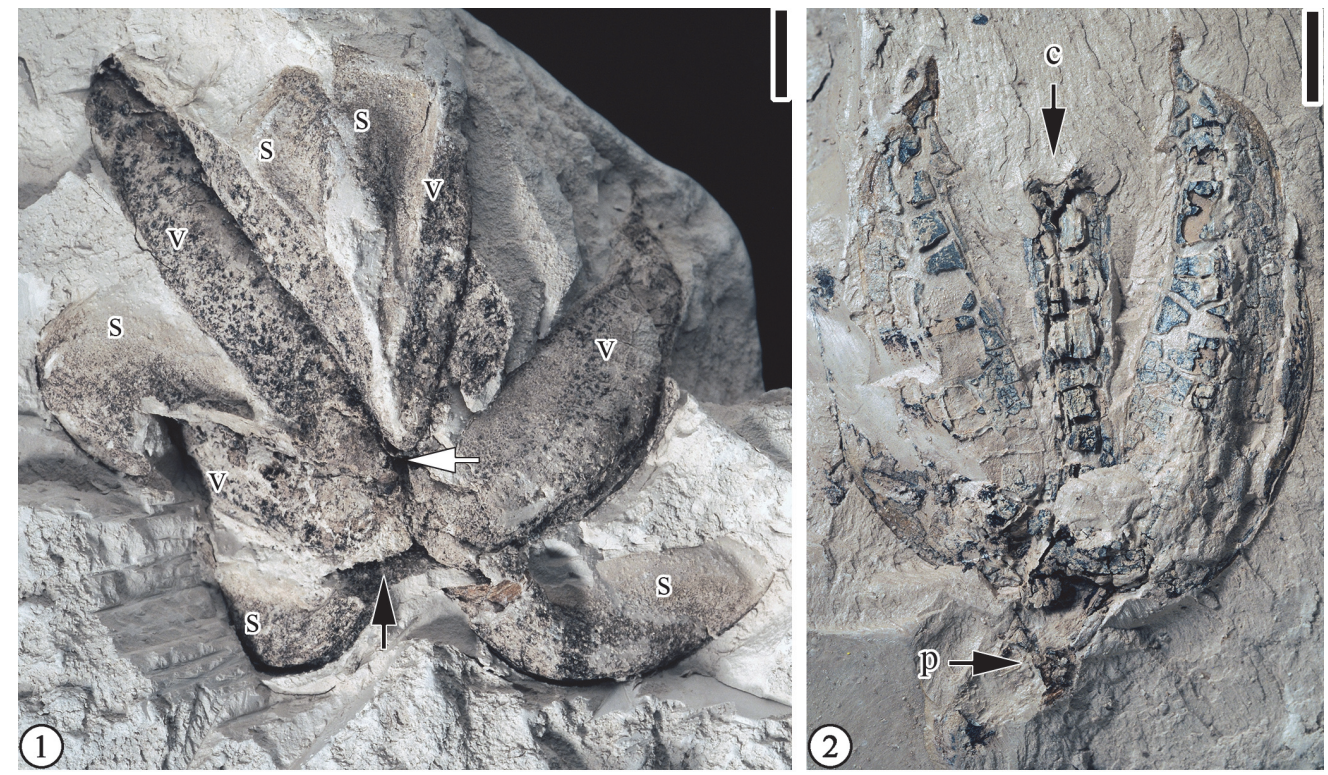

FIGURE 30. Andrewsiocarpon puryearensis sp. nov. 1) UF15820-61133, specimen showing five seeds (s) and four valves (v). Note the central columella is inferred by the circular depression (indicated by the white arrow) and the fifth valve is inferred by the depression at the bottom of the capsule (indicated by the black arrow). Scale bar equals 5 $\mathrm{mm}$; 2) UF15820-059410, showing two laterally compressed valves, pedicel (p), and a central columella (c). Scale bar equals $5 \mathrm{~mm}$.

Holotype. Designated here. UF15820-061133.

Paratype. UF15820-059410.

Number of specimens examined. 2. UF15820059410, 061133.

Species epithet etymology. Referring to the occurrence of this species in the Puryear locality, Tennessee.

Remarks. Both the capsules and the seeds are larger than those of Andrewsiocarpon henryense or Gordonia sp. (Grote and Dilcher, 1989; Wang et al., 2013). The new species also differs from them in the presence of a medial ridge and a distinct beak on each valve.

Berry (1916b, p. 288, pl. 72, figure 4) described one specimen from the same locality and assigned it to Sterculiocarpus sezannelloides. Sterculiocarpus is a fossil genus that Berry (1916b, p. 287) established "for fruits referable to the family Sterculiaceae, but without exact living representatives." Although similar to our current specimen in size and in possessing five valves, Berry's specimen contains numerous elliptical seeds.

Berry (1916b, p. 288, pl. 74, figures 1-3) described another five-valved fruit from DeSoto Parish, Louisiana, and assigned it to Sterculiocarpus eocenicus. This specimen is dramatically larger $(6 \mathrm{~cm}$ long and $6 \mathrm{~cm}$ wide) than both Andrewsiocarpon puryearensis and Sterculiocarpus sezannelloides.
Order APIALES Nakai, 1930

Family ARALIACEAE de Jussieu, 1789

Genus PALEOPANAX Manchester, 1994

Type species. Paleopanax oregonensis Manchester, 1994

Paleopanax puryearensis sp. nov.

Figure 31

Diagnosis. Fruit about $1 \mathrm{~cm}$ in diameter, orbicular, indehiscent, with two persistent styles, an epigynous disc, and a long pedicel; carpels two, Dshaped.

Description. Laterally compressed orbicular fruit ca. $1.2 \mathrm{~cm}$ wide and $1 \mathrm{~cm}$ long, indehiscent. Two persistent styles present, ca. $2 \mathrm{~mm}$ long, apex recurved. Epigynous disc present, ca. $3 \mathrm{~mm}$ in diameter. Pedicel ca. $1.1 \mathrm{~cm}$ long and $1 \mathrm{~mm}$ wide. Carpel D-shaped in face view, ca. $8 \mathrm{~mm}$ long and 5 $\mathrm{mm}$ wide; attached ventrally to the central fruit axis by its straight margin; dorsal margin convex. Mesocarp 0.5-1 mm thick.

Holotype. Designated here. UF15820-053151.

Paratype. UF15820-59481, 59481'.

Number of specimens examined. 2. UF15820053151, 59481.

Species epithet etymology. The species name refers to its occurrence at the Puryear locality, Tennessee.

Remarks. The presence of two persistent styles, two carpels, and epigynous disc is consistent with 


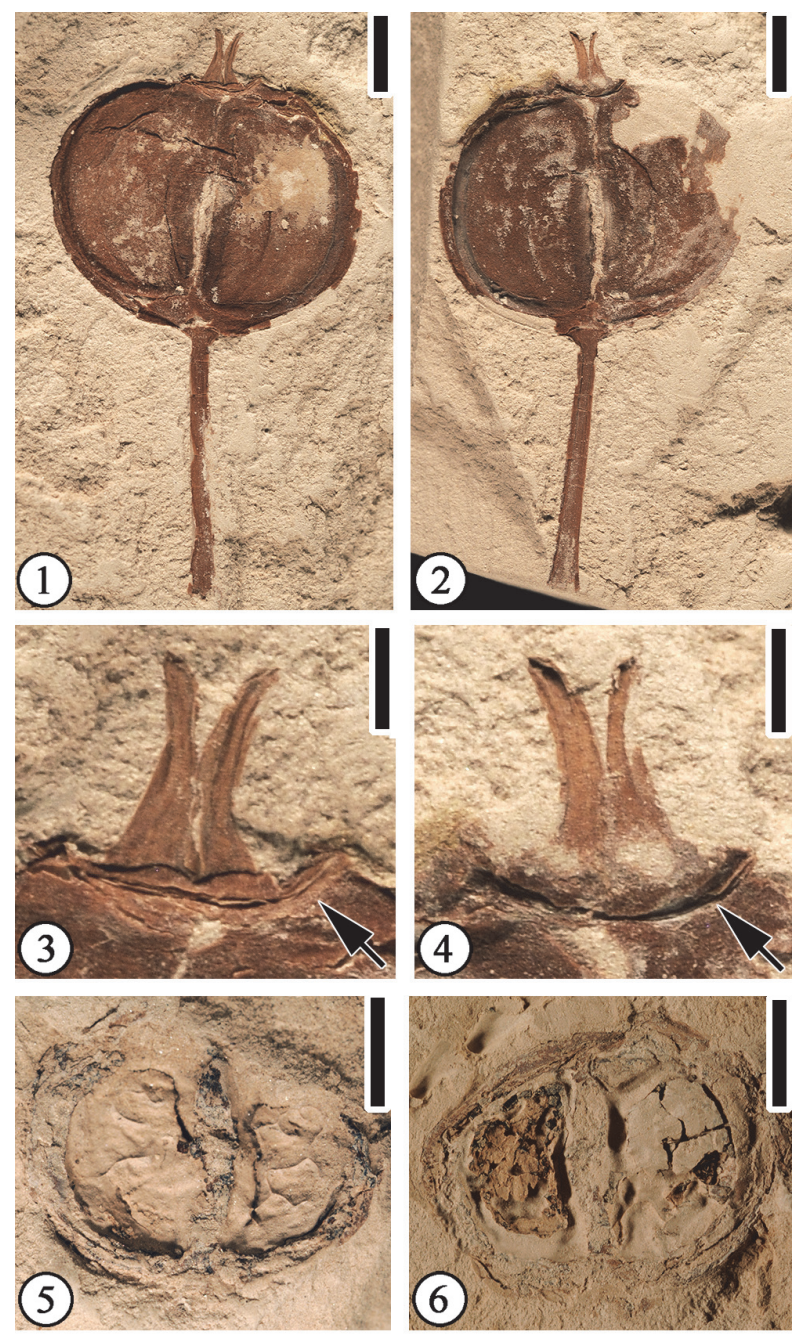

FIGURE 31. Paleopanax puryearensis sp. nov.: 1, 2) UF15820-053151, 053151', part and counterpart of the holotype specimen showing laterally compressed, orbicular fruit with two persistent styles, two D-shaped carpels, and a pedicel. Scale bars equal $3 \mathrm{~mm} ; 3,4$ ) Enlargements of Figure 31.1, 2, respectively, to show the curved styles and an epigynous disc (indicated by arrows). Scale bars equal $1 \mathrm{~mm} ; 5,6)$ UF15820-59481, 59481', part and counterpart of the paratype specimen showing D-shaped carpels. Scale bars equal $3 \mathrm{~mm}$.

the description of the type species, Paleopanax oregonensis, and suggests this fossil genus' affinity with the modern family Araliaceae.

Manchester et al. (2015, p. 350 , figure $18 \mathrm{~A}$ ) illustrated this specimen in discussing the fossil record of the Araliaceae, but they did not provide a description. We here formally establish a new species for this specimen. The diagnostic characters of the new species are consistent with those of the fruits from the middle Eocene Nut Beds Flora, Clarno Formation, Oregon (Manchester, 1994, pp.
38-39, pl. 7, figures 3-4) and late early Eocene Bolden locality, Tallahatta Formation, Mississippi (Blanchard et al., 2016, p. 29, figure 24). However, the Puryear specimen is about two times larger than the fruits from Oregon and Mississippi.

Petrified wood with possible affinity to Araliaceae was reported by Wheeler and Manchester (2014) from the Clarno Formation.

Leaves belonging to the family Araliaceae, i.e., Dendropanax eocenensis Dilcher and Dolph, was reported from other Claiborne localities (Dilcher and Dolph, 1970). These leaves are also present at the Puryear locality. However, the relationship between these araliaceous leaves and fruits are unknown.

Berry (1930, p. 66, pl. 48, figure 8 ) described a similar fossil fruit from the Puryear locality and assigned it to "Ficus" fructus pedicellata. (mistakenly listed as "Ficus" myrtifolia ovata Berry in the text). Berry's specimen differs from the new species, Paleopanax puryearensis, in that "Ficus" fructus pedicellata does not have D-shaped carpels, and the fruit is much smaller $(10 \mathrm{~mm}$ long and 12 $\mathrm{mm}$ wide vs. $8 \mathrm{~mm}$ long and $10 \mathrm{~mm}$ wide).

Extant Araliaceae has about 50 genera mainly distributed in subtropical to tropical regions in both hemispheres and a few in temperate areas (Watson and Dallwitz, 1992 onwards; Xiang and Lowry, 2007; Xiang and Lowry, 2008). Manchester (1994) noted that the morphology of Paleopanax fruits is similar to the extant genus Pseudopanax. This is significant because Pseudopanax, with about 80 species of evergreen trees and shrubs, is native to New Zealand, Tasmania, New Caledonia, and Chile (Wen, 2001). Wen Jun (2019, personal communication) suggested that the Puryear fossil fruits are reminiscent of Metapanax, a genus presently distributed mostly in central and southwestern China and extending to northern Vietnam (Wen and Frodin, 2001).

Order LAMIALES Bromhead, 1838

Family OLEACEAE Hoffmannsegg and Link, 1809

Genus FRAXINUS Linnaeus, 1753

Fraxinus wilcoxiana (Berry) Call and Dilcher, 1992 Figure 32

1916 Fraxinus wilcoxiana Berry, p. 340, pl. 101, fig. 5.

1992 Fraxinus wilcoxiana Berry; Call and Dilcher, p. 253, pl. I, figs. 2-11; pl. II, figs. 15-21, 23; pl. III, figs. 24-32.

2013 Fraxinus wilcoxiana Berry; Wang, Blanchard and Dilcher, p. 36, fig. 29.

Description. Fruits pedicellate; pedicel short, stout (1.5 $\mathrm{mm}$ long and $0.5 \mathrm{~mm}$ wide) to long $(3.5 \mathrm{~mm}$ long and $0.3 \mathrm{~mm}$ wide); fruit flattened, bilaterally 


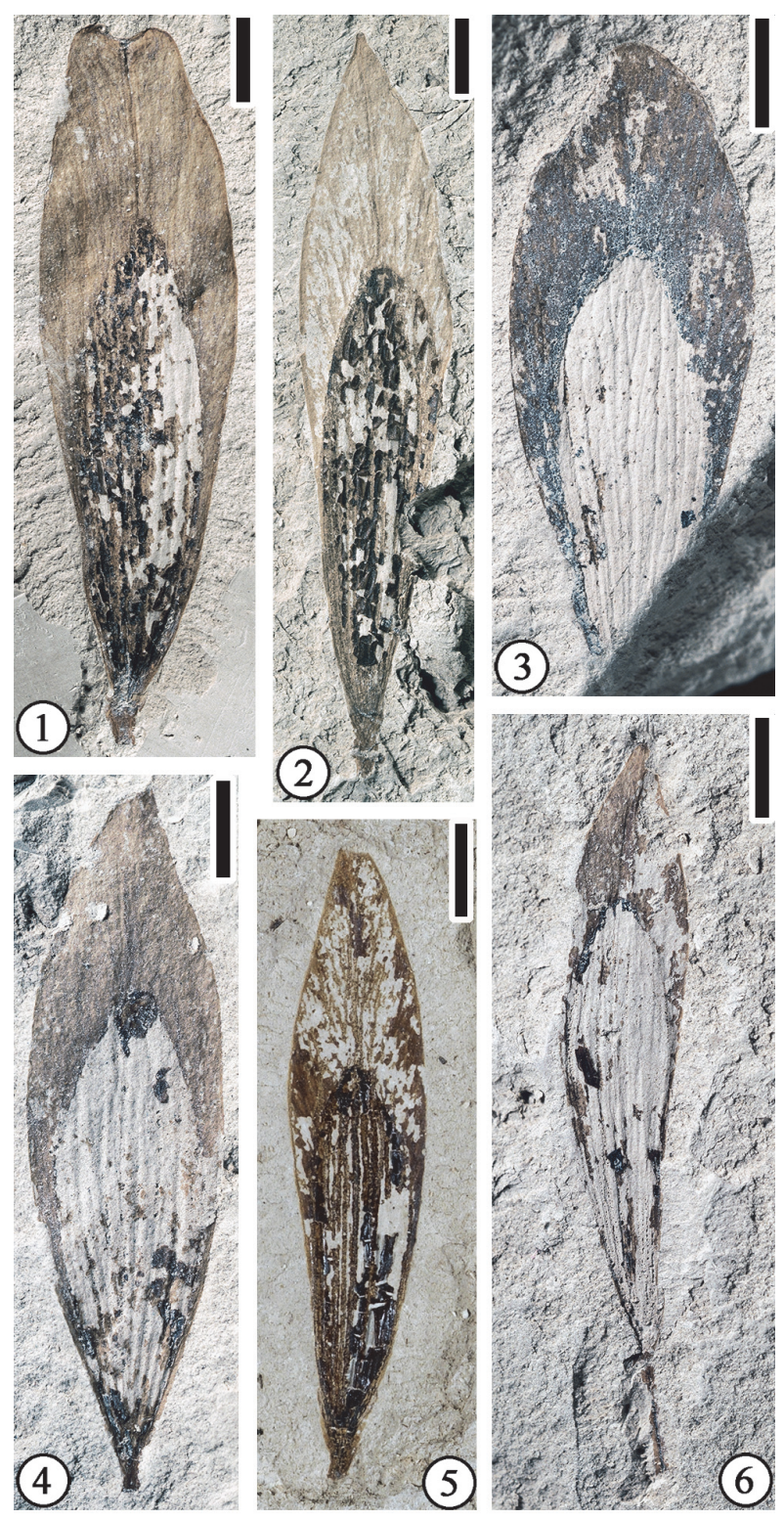

FIGURE 32. Fraxinus wilcoxiana (Berry) Call and Dilcher, 1992: 1) UF15820-011008, specimen showing an emarginate wing apex; 2) UF15820-011010, specimen showing a well-demarcated seed and acute wing apex; 3) UF15820-011016, specimen showing a welldemarcated seed and rounded apex; 4) UF15820011014, specimen showing a narrow elliptic samara; 5) CONN-Q11-P1a, specimen showing a relatively large seed and a short, stout pedicel; 6) UF15820-011001, specimen showing a relatively long pedicel. All scale bars equal $3 \mathrm{~mm}$.

symmetrical, single-seeded samaras consisting of a striate, obovate fruit body with a laterally decurrent, apically extended wing; samara $18-28 \mathrm{~mm}$ long and 4-7 $\mathrm{mm}$ wide, subtended by a persistent synsepalous calyx with acute lobes free nearly to base; seed elliptic to obovate, $12-16 \mathrm{~mm}$ long and 3-4.1 mm wide; wing apex emarginate, acute, or rounded.

Number of specimens examined. 27. UF15820011008, 011010, 011016, 011014, 011001; CONNQ11-P1a.

Remarks. Call and Dilcher (1992) reported 22 specimens from the Puryear clay pit and three specimens from the Warman clay pit. Wang et al. (2013) re-illustrated two specimens which were listed by Call and Dilcher (1992) from the Warman clay pit. Here we illustrate additional specimens from the Puryear clay pit. Observation of fossil fruits collected from the Warman and Puryear clap pits indicates that dimensional variation is more or less comparable to that among samaras of a single tree of the extant species sampled, and that fossil samaras are short and somewhat narrow in comparison with fruits of several extant species investigated, suggesting that fruit evolution in Fraxinus has involved an increase in fruit size (Call and Dilcher, 1992).

\section{Angiosperm Incertae Sedis - Flowers \\ "Calycites" puryearensis Berry 1930 Figure 33}

Description. Laterally compressed floral structure consisting of five (six?) lanceolate perianth parts ca. 11-14 mm long and $3 \mathrm{~mm}$ wide at the base; ca. 5 fine, parallel veins present in each part; apex attenuate, surface pubescent; anthers $0.2-0.3 \mathrm{~mm}$ long and $0.2 \mathrm{~mm}$ wide, clinging to the surface of the perianth part.

Number of specimens examined. 2. UF15820059460, 043599.

Remarks. Calycites is a fossil genus established by Berry (1930) for three different types of floral structures from the Claiborne Group in Tennessee. Calycites milanensis Berry (1930, p. 142, pl. 49, figures 6-8) is based on five specimens from the Holly Springs sand, 1 mile west of Milan, Gibson County, Tennessee. The largest floral structure is $2.6 \mathrm{~cm}$ in diameter. Berry described C. milanensis as "a large gamosepalous calyx divided for onethird to one-half the distance inward toward the round hole representing the receptacle into five parabolically rounded lobes." He suggested that these floral structures might be related to Diospyros (Ebenaceae). The second type, Calycites rhizophoroides Berry (1930, pp. 142-143, pl. 45, figure 12), also of unknown affinity, is a tetramerous coriaceous calyx $(2.4 \mathrm{~cm}$ in diameter) from Grable pit, Henry County, Tennessee. 

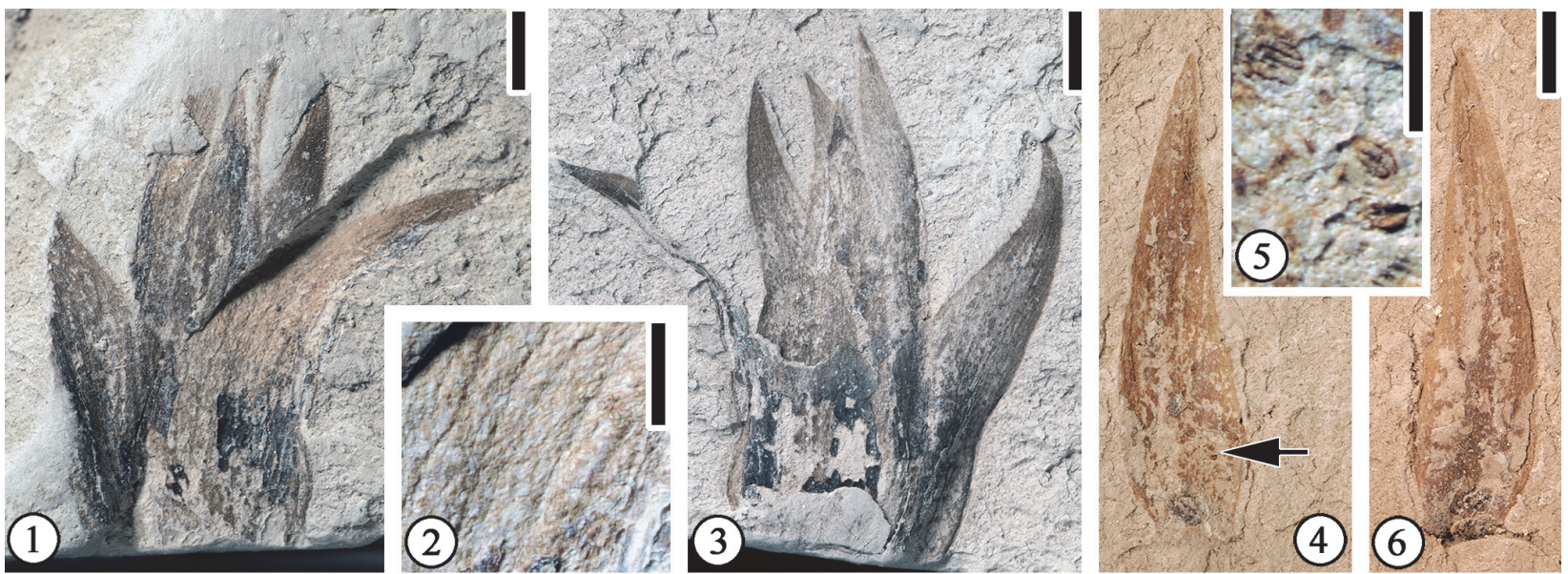

FIGURE 33. "Calycites" puryearensis Berry, 1930: 1) UF15820-059460', specimen showing six floral parts. Scale bar equals $2 \mathrm{~mm}$; 2) Enlargement of the middle portion of a floral part in Figure 33.1 to show venation and trichomes. Scale bar equals $1 \mathrm{~mm}$; 3) UF15820-059460, counterpart of Figure 33.2 showing five floral parts with acute apices. Scale bar equals 2 mm; 4) UF15820-043599, a dispersed floral part. Scale bar equals 2 mm; 5) Enlargement of Figure 33.4 (indicated by arrow) to show anthers clinging to the floral part. Scale bar equals $0.5 \mathrm{~mm}$; 6) counterpart of Figure 33.4. Scale bar equals $2 \mathrm{~mm}$.

The third type, Calycites puryearensis Berry (1930, p. 142, pl. 48, figure 4), is based on two specimens (he only illustrates one) from Puryear that closely resemble ours. Berry described it as a five-lobed calyx with five lanceolate lobes and a short peduncle. However, his illustration does not show the presence of a peduncle or pedicel. His illustration does show apices of six lanceolate parts with basal portions superimposed, like the specimen we describe here. The six floral parts may slightly overlap at the base and when compressed, they do look like one calyx with six lobes rather than six individual floral parts.

In this report, we treat Berry's illustrated Calycites puryearensis (1930, p. 142, pl. 48, figure 4) specimen as the same type as our specimens. We retain Berry's species epithet but add quotations marks to the generic name to indicate that this fossil species should probably be moved to a different genus. This is because that one dispersed floral part (Figure 33.4-6) has at least four anthers (0.2$0.3 \mathrm{~mm}$ long and $0.2 \mathrm{~mm}$ wide) clinging to the base. Considering the floral structure has six parts, it may represent a monocot flower.

\section{Claiborne Floral Type 2 \\ Figure 34}

Description. A laterally compressed flower ca. 9 $\mathrm{mm}$ long (including pedicel) and $12 \mathrm{~mm}$ wide (between the apices of two lateral perianth parts); perianth parts (three observed) ca. $6 \mathrm{~mm}$ long and $3 \mathrm{~mm}$ wide, fused for one-third of their length; free parts ca. $4 \mathrm{~mm}$ long, triangular; a mid-vein present, extending directly to the apices; lateral veins faint, reticulate. Ovary superior, ca. $2 \mathrm{~mm}$ in diameter. Pedicel short, $2 \mathrm{~mm}$ long and $1 \mathrm{~mm}$ wide.

Number of specimens examined. 1. UF15820002247, 002247'.

Remarks. This Puryear specimen has been assigned to the same morphotype as a specimen from the Warman locality (Wang et al., 2013, p. 46, figure 36.3-4). It differs from the Warman specimen in that trichomes are not observed, and a midvein is present on each perianth part. However, we place it in the same type as the Warman specimen based on the fact that they both have a superior ovary and triangular perianth parts that are fused at the base.

\section{Claiborne Floral Type 5 \\ Figure 35}

Description. Vertically preserved flower ca. $2 \mathrm{~cm}$ in diameter with five persistent perianth parts and a hypogynous ovary containing five triangular carpels. Ovary $5 \mathrm{~mm}$ in diameter. Perianth parts distinct, each $8 \mathrm{~mm}$ long and $6 \mathrm{~mm}$ wide, containing one major medial vein, and 3-4 thinner, parallel veins on each side. Medial vein extending to the apex and thinner veins branching at various distances from the base to form minor, reticulate veins.

Number of specimens examined. 1. UF15820061132. 

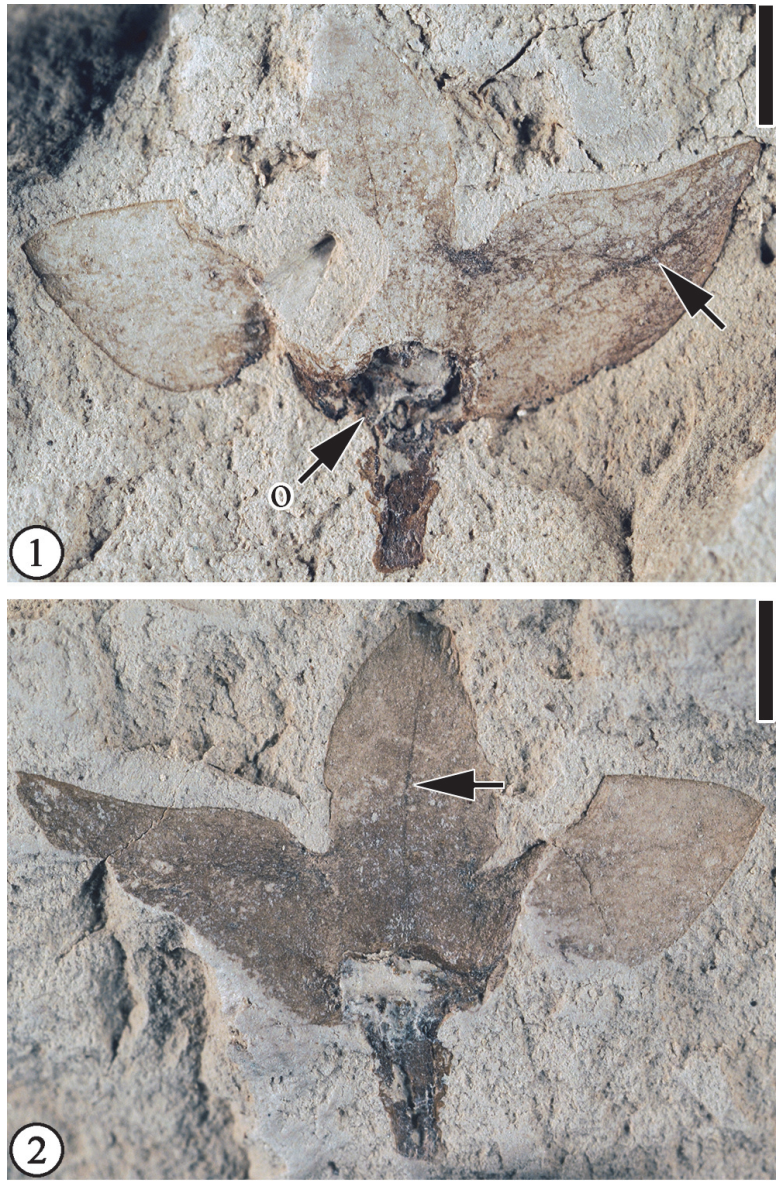

FIGURE 34. Claiborne Floral Type 2: 1) UF15820002247 , flower with a superior ovary (0) which is represented by the depression. Note midvein of a perianth part (indicated by arrow); 2) UF15820-002247', counterpart of flower showing three perianth parts fused at the base and midvein of one perianth part (indicated by arrow). All scale bars equal $2 \mathrm{~mm}$.

Remarks. This is a very common floral type that has also been described from the Warman clay pit, Tennessee (Wang et al., 2013, figure 39), and the Bolden clay pit, Mississippi (Blanchard et al., 2016, figure 27, table 4; also Table 4 in this paper). This specimen from the Puryear locality does not display any new characters but the presence of five persistent perianth parts and a hypogynous ovary containing five triangular carpels, and the venation

TABLE 4. Comparison of characters of Claiborne floral types. All dimensions are in millimeters $(\mathrm{mm})$. "?" indicates that a measurement is not available, or a character is not observed. Available as spreadsheet file for download at https://palaeo-electronica.org/content/2020/3177fossil-plants-from-tennessee.
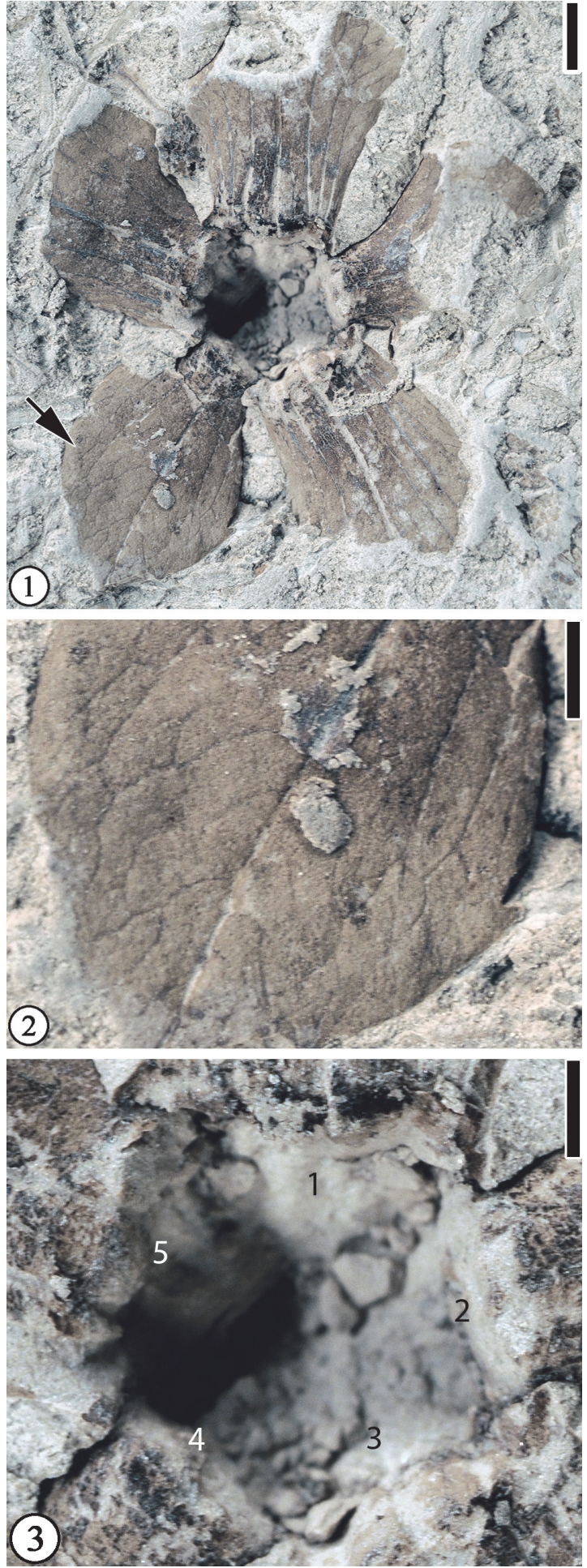

FIGURE 35. Claiborne Floral Type 5: 1) UF15820061132, showing a vertically preserved flower with five persistent perianth parts. Scale bar equals $2 \mathrm{~mm}$; 2) Enlargement of a perianth part in Figure 35.1 (indicated by arrow) to show reticulate fine venation. Scale bar equals $1 \mathrm{~mm}$; 3) Enlargement of the ovary in Figure 35.1 to show triangular carpels (indicated by numbers). Scale bar equals $1 \mathrm{~mm}$. 


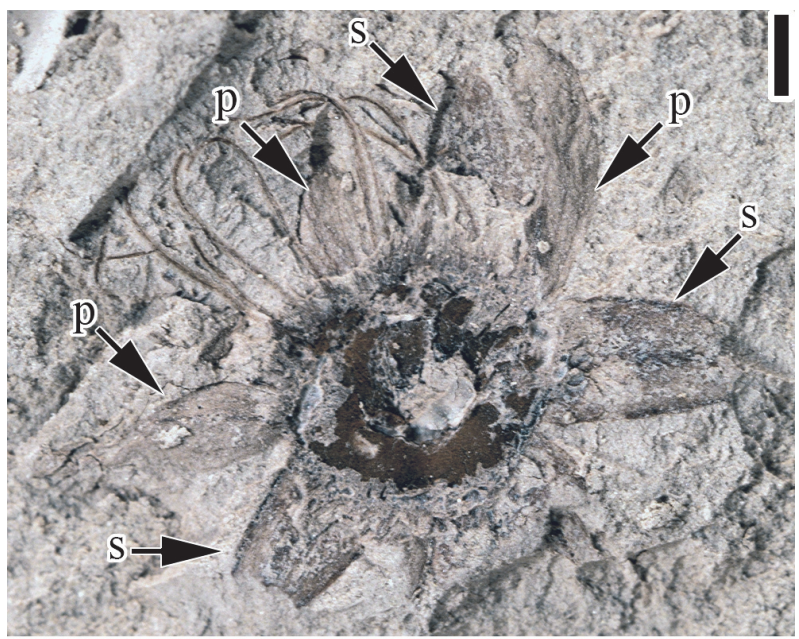

FIGURE 36. Claiborne Floral Type 8: UF15820-059478, flower showing alternating sepals (s) and petals ( $p$ ), and filaments. Note even distribution of filaments. Scale bar equals $1 \mathrm{~mm}$.

of the perianth parts are consistent with those of specimens from the Bolden and Warman localities.

\section{Claiborne Floral Type 8 \\ Figure 36}

Description. Vertically compressed flower $8 \mathrm{~mm}$ in diameter; ovary inferior. Sepals alternating with petals; sepals equilateral or isosceles-triangular in shape, $2.5 \mathrm{~mm}$ long and $2 \mathrm{~mm}$ wide at the base. Petals thin, not well preserved. Three sepals and three petals in two separate whorls. Well-developed hypanthium circular in vertical view $(2 \mathrm{~mm}$ in diameter) with a distal rim ca. $0.5 \mathrm{~mm}$ thick. Filaments at least 10 , each at least $3 \mathrm{~mm}$ long and ca. $0.1 \mathrm{~mm}$ wide, evenly distributed on the rim of the hypanthium; anthers not observed.

Number of specimens examined. 1. UF15820059478.

Remarks. Three sepals and three petals are observed in this flower, and they can be distinguished by their color and position of attachment on the circular hypanthium rim. Based their position, there are probably four sepals and four petals, indicating a 4-merous flower. Like the Bovay specimens (Blanchard et al., 2016, figure 29), the Puryear specimen shows an even distribution of filaments on the rim of the hypanthium. Unlike the Bovay specimens, this specimen from Puryear shows distinctly different petals and sepals.

\section{Claiborne Floral Type 15}

Figure 37

Description. Laterally preserved flower 2-3 mm long and $3-5 \mathrm{~mm}$ wide with three perianth parts
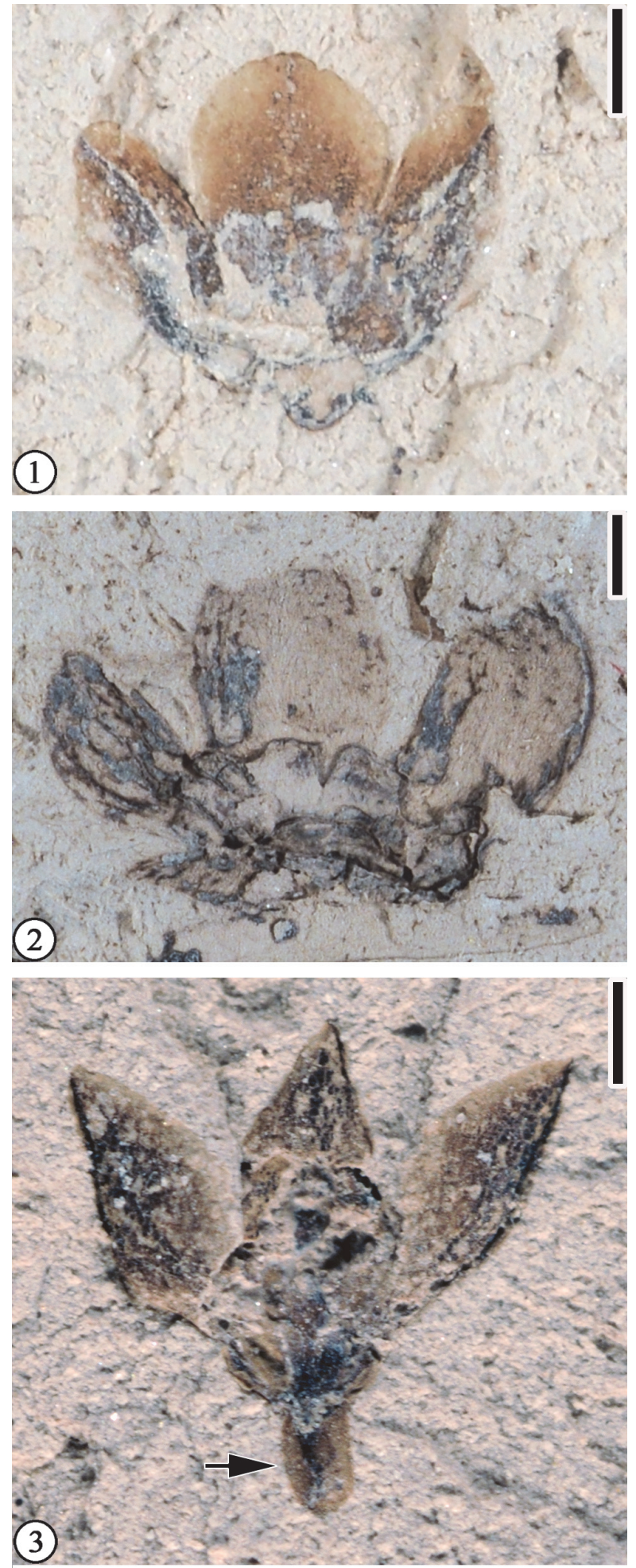

FIGURE 37. Claiborne Floral Type 15: 1) CONN-Q6-02 and 2) UF15820-004686, laterally preserved flowers showing three perianth parts. Note rounded apex of the middle perianth part; 3) UF15820-059404, laterally compressed flower with three perianth parts and a short pedicel (indicated by arrow). All scale bars equal $1 \mathrm{~mm}$. 
each ca. $1.5-2.5 \mathrm{~mm}$ long and $1-2.5 \mathrm{~mm}$ wide. Apex of each perianth part rounded or acute. Receptacle obtriangular, $0.5 \mathrm{~mm}$ long and $0.75 \mathrm{~mm}$ wide. Pedicel short, ca. $0.5 \mathrm{~mm}$ long and $0.4 \mathrm{~mm}$ wide.

Number of specimens examined. 3. UF15820059404, CONN-Q6-02, Q7-P4686.

Remarks. These specimens are the same as Claiborne Floral Type 15 from the Bovay locality (Blanchard et al., 2016, p. 37, figure 36) in having three perianth parts with similar size and shape but with greater minimum width, except that a perianth part may have a rounded apex. The shape of the perianth parts varies, even in one specimen (Figure 37.1). This variation might be the result of folding of the distal portion of the perianth parts before deposition/preservation. In Figure 37.3, the circular depression may represent a compressed ovary.

\section{Claiborne Floral Type 18}

Figure 38

Description. Laterally preserved flower with clustered stamens and fused filaments, at least two perianth parts, and a short pedicel. Filament column ca. $1.5 \mathrm{~mm}$ long and $0.5 \mathrm{~mm}$ wide, with at least six anthers. Anthers $1-1.5 \mathrm{~mm}$ long and 0.5 $\mathrm{mm}$ wide. Perianth part curved, with acute apex, $2.5 \mathrm{~mm}$ long and $1.2 \mathrm{~mm}$ wide. Pedicel $1.5 \mathrm{~mm}$ long and $0.5 \mathrm{~mm}$ wide.

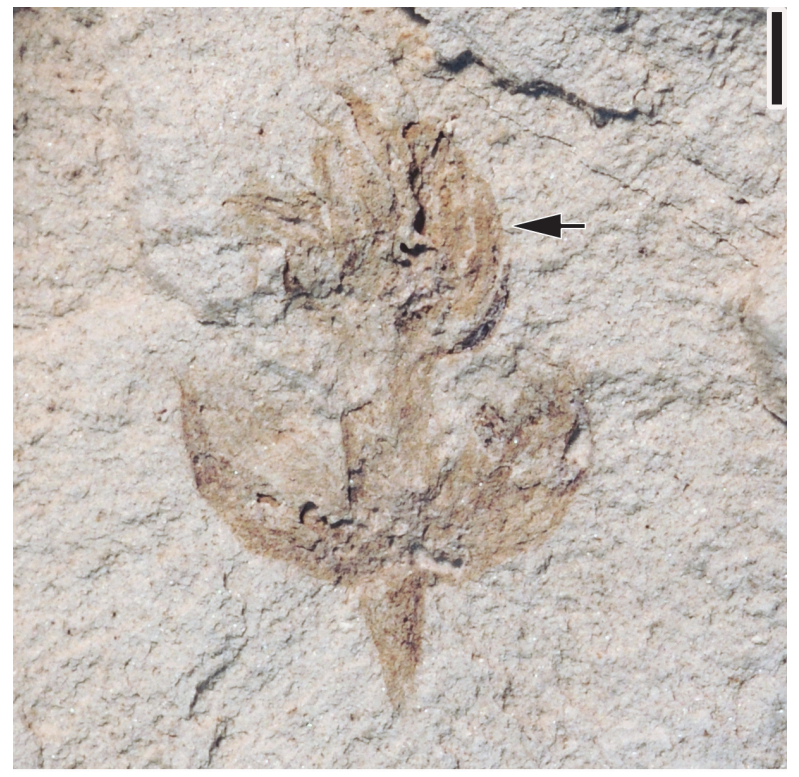

FIGURE 38. Claiborne Floral Type 18: CONN-Q1-P120, laterally preserved flower with clustered stamens (indicated by arrow) and fused filaments, at least two perianth parts, and a short pedicel. Scale bar equals $1 \mathrm{~mm}$.
Number of specimens examined. 1. CONN-Q1P120.

Remarks. This specimen from Puryear belongs to the same floral type from the Bovay clay pit (Blanchard et al., 2016, p.38, figure 39). The ovary of this flower is not as obvious as those specimens from the Bovay locality.

\section{Claiborne Floral Type 21 Figure 39}

Description. Petal, broadly obovate in outline, ca. $2.2 \mathrm{~cm}$ long and ca. $2.4 \mathrm{~cm}$ wide distally. Base slightly concave ca. $0.5 \mathrm{~cm}$ wide. A prominent midvein present, extending directly to the midpoint of notched apex; finer veins from both the midvein and the truncated base exmedially curved and forking 3-5 times before reaching the margin.

Number of specimens examined. 1. UF15820059487.

Remarks. This detached petal represents one part of a large flower at least $5 \mathrm{~cm}$ in diameter. The venation pattern of the petal differs from other known flowers from the Claiborne Group. Berry (1930) mentioned the occurrence of many large flower petals, varying somewhat in shape, and some of which are emarginate at the apex. He did not assign them to any taxa or illustrate them.

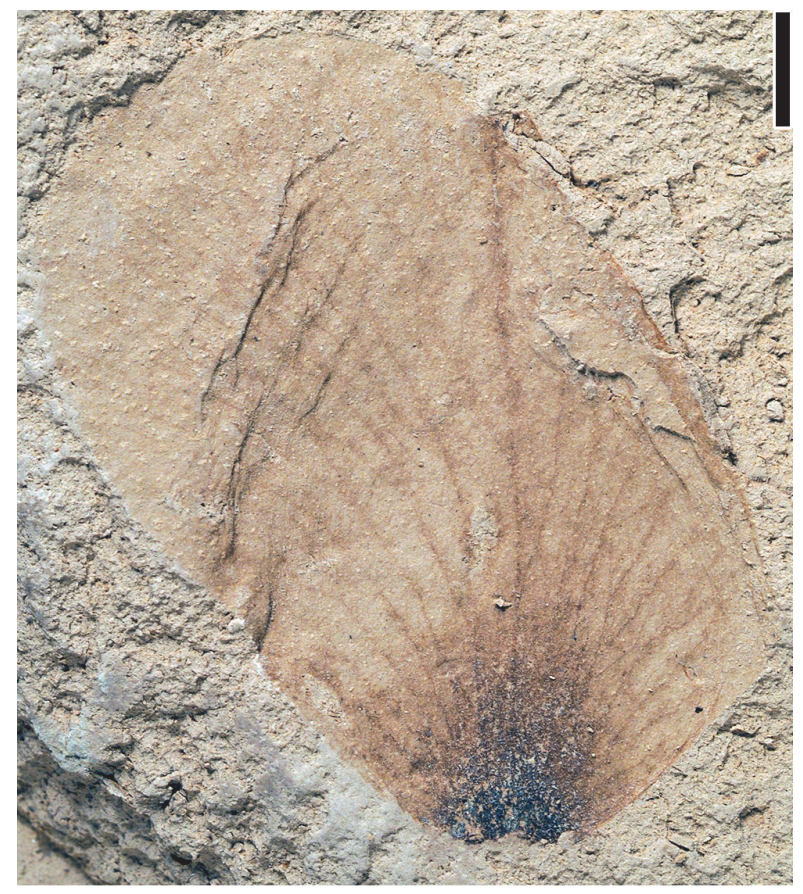

FIGURE 39. Claiborne Floral Type 21: UF15820059487, showing a broadly obovate petal with a prominent midvein and forking fine veins. Scale bar equals 3 $\mathrm{mm}$. 

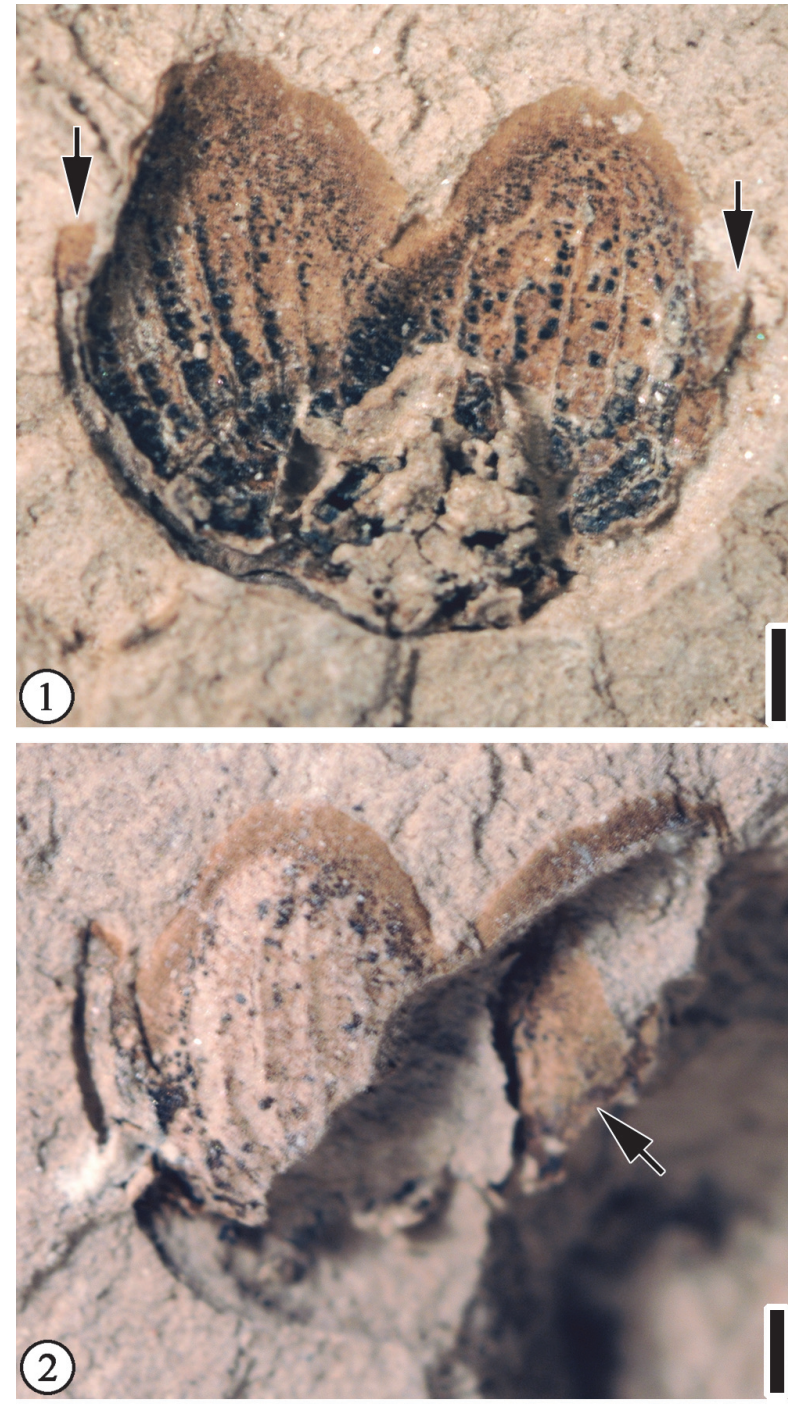

FIGURE 40. Claiborne Floral Type 22: 1) UF15820002244a', showing a laterally preserved flower. The third and fourth perianth parts are indicated by arrows. Note the parallel veins on the two perianth parts in the middle; 2) UF15820-002244a, counterpart showing the fifth floral part (indicated by arrow). All scale bars equal $0.5 \mathrm{~mm}$.

Berry (1930, p. 54, pl. 29, figure 5) assigned one specimen which is from the Holly Springs sand locality north of Shandy, Hardeman County, Tennessee, to Potamogeton, and described it as a floating leaf. This specimen, possibly representing a petal, differs from the Puryear specimen in having fine veins that converge at the rounded apex.

\section{Claiborne Floral Type 22}

Figure 40

Description. Laterally preserved flower showing two complete perianth parts ca. $3 \mathrm{~mm}$ long and 2

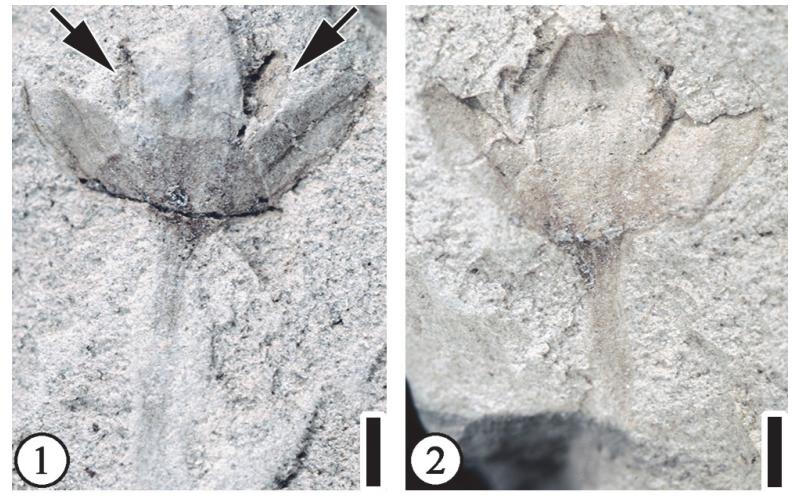

FIGURE 41. Claiborne Floral Type 23: 1) UF15820002259', laterally preserved flower with five perianth parts. The fourth and fifth parts are indicated by arrows. Note prominent midveins of the perianth parts; 2) UF15820-002259, counterpart showing the elliptic shape, represented by the central perianth part. All scale bars equal $1 \mathrm{~mm}$.

$\mathrm{mm}$ wide, and three incomplete perianth parts. Each perianth part with six or seven parallel veins that diminish near the rounded apex. Partial remains of ovary ca. $1.5 \mathrm{~mm}$ in diameter.

Number of specimens examined. 1. UF15820002244a.

Remarks. This specimen is similar to Claiborne Floral Type 15 from the Bovay locality in Mississippi (Blanchard et al., 2016, p.37, figure 36). It differs from Claiborne Floral Type 15 in having larger perianth parts with rounded apices and relatively strong venation, and in the absence of a receptacle or pedicel.

\section{Claiborne Floral Type 23}

Figure 41

Description. Laterally compressed flower ca. 3 $\mathrm{mm}$ long and $4 \mathrm{~mm}$ wide; five perianth parts observed, elliptic, each ca. $3 \mathrm{~mm}$ long and $2 \mathrm{~mm}$ wide, with a prominent, straight midvein extending to the acute apex. Pedicel at least $5 \mathrm{~mm}$ long and $0.5 \mathrm{~mm}$ wide.

Number of specimens examined. 1. UF15820002259.

Remarks. This flower differs from other similarly sized flowers (Table 4) from the Claiborne in having a long pedicel and a single whorl of five perianth parts with prominent, straight midveins.

\section{Claiborne Floral Type 24}

Figure 42

Description. Laterally compressed flower $9 \mathrm{~mm}$ long and $5 \mathrm{~mm}$ at the widest point. Pedicel $3 \mathrm{~mm}$ long and $1.5 \mathrm{~mm}$ wide. At least three perianth parts 


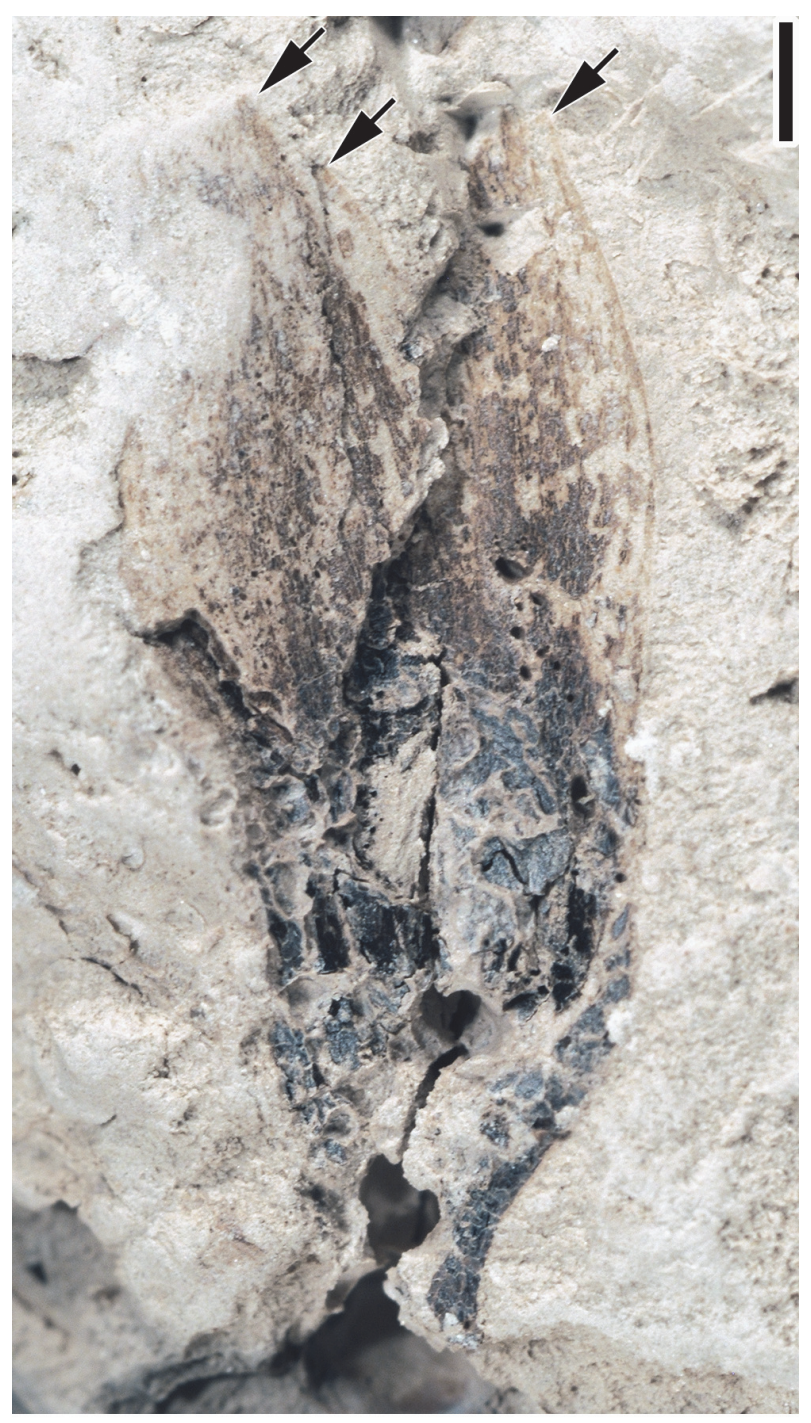

FIGURE 42. Claiborne Floral Type 24: UF15820043622a, laterally compressed flower with a short pedicel and at least three perianth parts (indicated by arrows). Scale bar equals $1 \mathrm{~mm}$.

visible, tapering towards the apices. Fine longitudinal striations present.

Number of specimens examined. 1. UF15820043622a.

Remarks. The dark area in the middle of this floral type probably indicates the presence of an ovary. The morphology of the perianth parts is similar to the specimen identified as Carpolithus plumosus (Berry, 1930, pl. 48, figure 3) and "Calycites" puryearensis (Berry, 1930, pl. 48, figure 4; Figure 33). The new floral type differs from them in that it has a short pedicel and an ovary.

\section{Claiborne Floral Type 25}

Figure 43

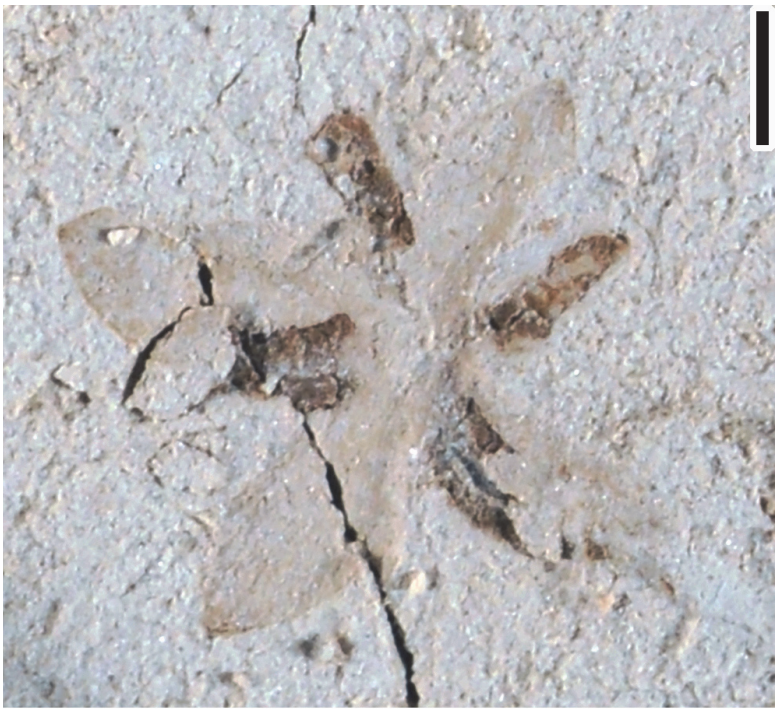

FIGURE 43. Claiborne Floral Type 25: CONN-P121, vertically compressed flower with two whorls of floral parts. Scale bar equals $1 \mathrm{~mm}$.

Description. Vertically compressed flower with two whorls of floral parts; 4 light-colored parts (petals?) alternately arranged with 4 dark-colored parts (sepals?); light-colored floral parts elliptic, $2 \mathrm{~mm}$ long and $1 \mathrm{~mm}$ wide; dark-colored floral parts ca. 1 $\mathrm{mm}$ long and $0.5 \mathrm{~mm}$ wide.

Number of specimens examined. 1. CONNP121.

Remarks. This floral type may belong to the same taxon, cf. Populus sp., reported from the Bolden clay pit, Mississippi, by Blanchard et al. (2016, p. 15, figure 13). They both are 4-merous and have floral parts of the same size. We temporarily treat them as two types since the Puryear specimen is smaller and has four more dark-colored floral parts. This floral type from Puryear differs from Eoceltis dilcheri Zavada and Crepet, 1981 (Figure 19 in this paper) in having two alternately arranged whorls of perianth parts, and smaller size.

\section{Claiborne Floral Type 26 \\ Figure 44}

Description. Laterally compressed flower with at least three floral parts, each ca. $10 \mathrm{~mm}$ long and 3 $\mathrm{mm}$ wide, with three acrodromous major veins and finer parallel veins, enclosing a suborbiculate part (ovary or fruit?), $5 \mathrm{~mm}$ long and $3 \mathrm{~mm}$ wide.

Number of specimens examined. 1. UF158202228.

Remarks. This floral type differs from other types in that its floral parts (petals?) have three acrodromous veins running in convergent arches toward the apices. 


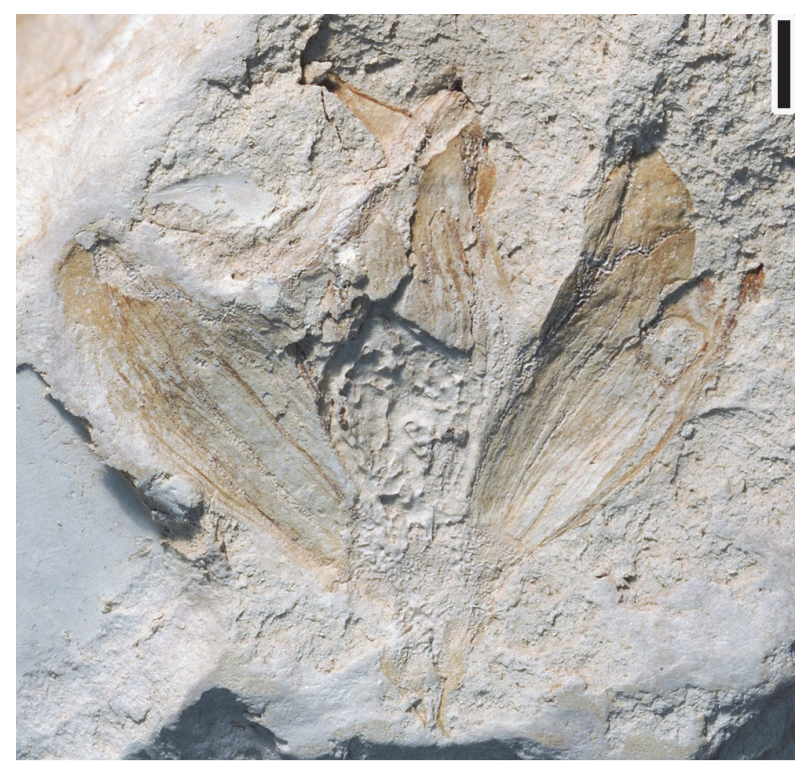

FIGURE 44. Claiborne Floral Type 26: UF15820002228, laterally compressed flower with at least three floral parts, each with three acrodromous major veins and finer parallel veins, enclosing a suborbiculate part (ovary or fruit?). Scale bar equals $2 \mathrm{~mm}$.

\section{Claiborne Floral Type 27}

Figure 45

Description. Flower at least $1 \mathrm{~cm}$ in diameter; perianth parts not well-preserved; Stamens numerous, attached to the base of perianth parts; anthers, narrow elliptic, $1 \mathrm{~mm}$ long and $0.2-0.5 \mathrm{~mm}$ wide; filaments ca. $4 \mathrm{~mm}$ long and $0.1-0.2 \mathrm{~mm}$ wide; connective extending the whole length of the anther.

Number of specimens examined. 3. CONN-Q0118, Q01-03, Q06-04a.

Remarks. These specimens are similar to Claiborne Floral Type 20 from the Bovay clay pit (Blanchard et al., 2016, p. 40, figure 41), Mississippi in that both floral types have numerous stamens. They differ in that the new floral type from Puryear has longer filaments, larger anthers $11 \mathrm{~mm}$ long and $0.2-0.5 \mathrm{~mm}$ vs ca. $0.8 \mathrm{~mm}$ long and 0.6 $\mathrm{mm}$ wide), and different anther shape (narrow elliptic vs suborbiculate).

\section{Claiborne Floral Type 28}

Figure 46

Description. Laterally compressed flower ca. 6 $\mathrm{mm}$ in diameter, with numerous filaments attached to a central point; filaments ca. $3 \mathrm{~mm}$ long and 0.2 $\mathrm{mm}$ wide; pedicel ca. $7 \mathrm{~mm}$ long and $1 \mathrm{~mm}$ wide; number of perianth parts unknown.

Number of specimens examined. 1. CONN-Q0611.
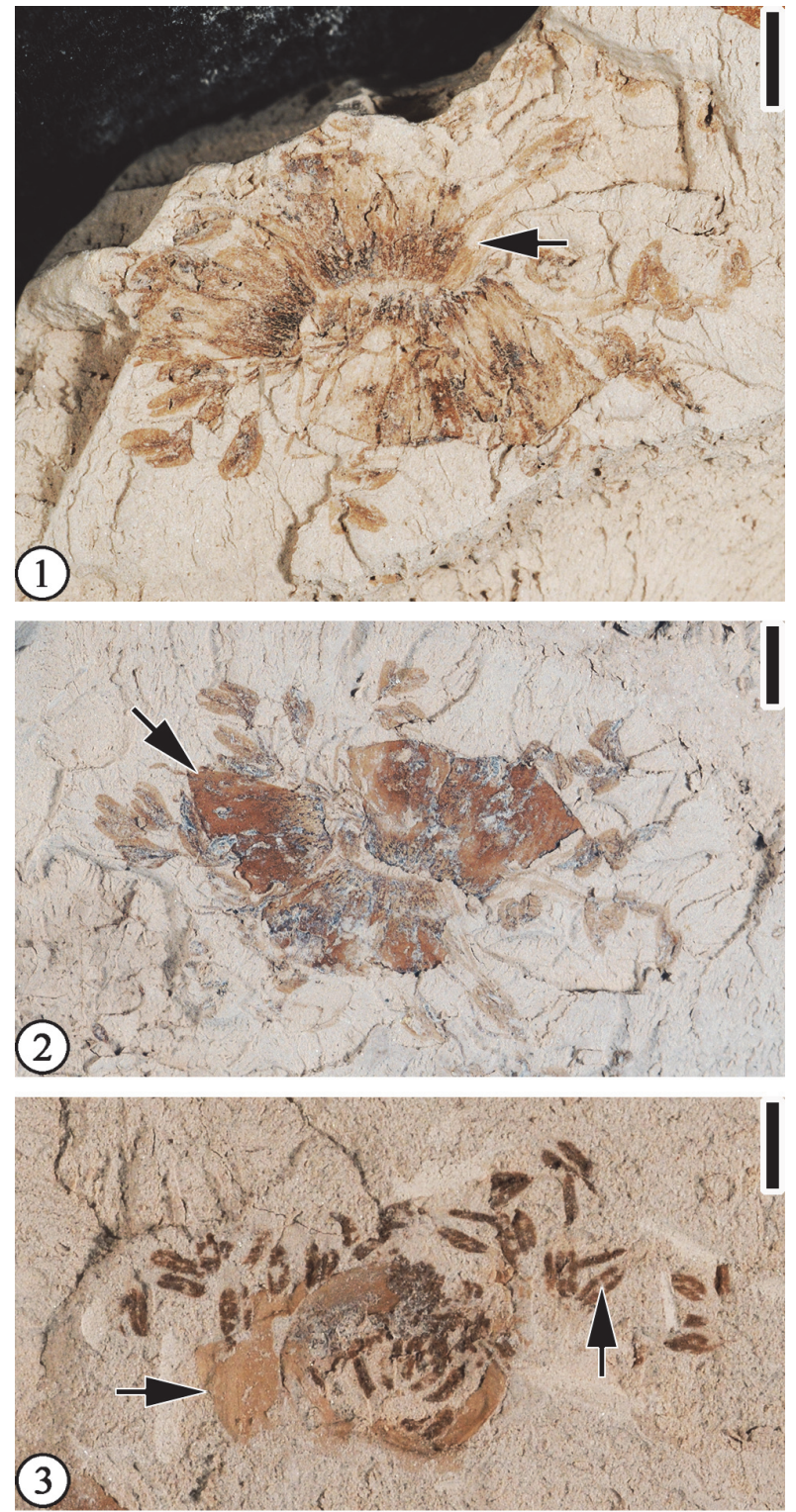

FIGURE 45. Claiborne Floral Type 27: 1) CONN-Q0118 , flower with stamens attached to the base of perianth part (indicated by arrow); 2) CONN-Q06-04a, flower with perianth parts (indicated by arrow) and stamens; 3 ) CONN-Q01-03, flower with perianth parts (indicated by arrow on the left) and numerous anthers. Note that the connective extends the whole length of the anther (indicated by arrow on the right). All scale bars equal $2 \mathrm{~mm}$.

Remarks. This floral type differs from Claiborne Floral Type 20 and 28, in that its filaments are attached to a central point instead of to the bases of the perianth parts (Table 4).

\section{Angiosperm Incertae Sedis - Infloresences}

\section{Claiborne Inflorescence Type 1}

Figure 47 

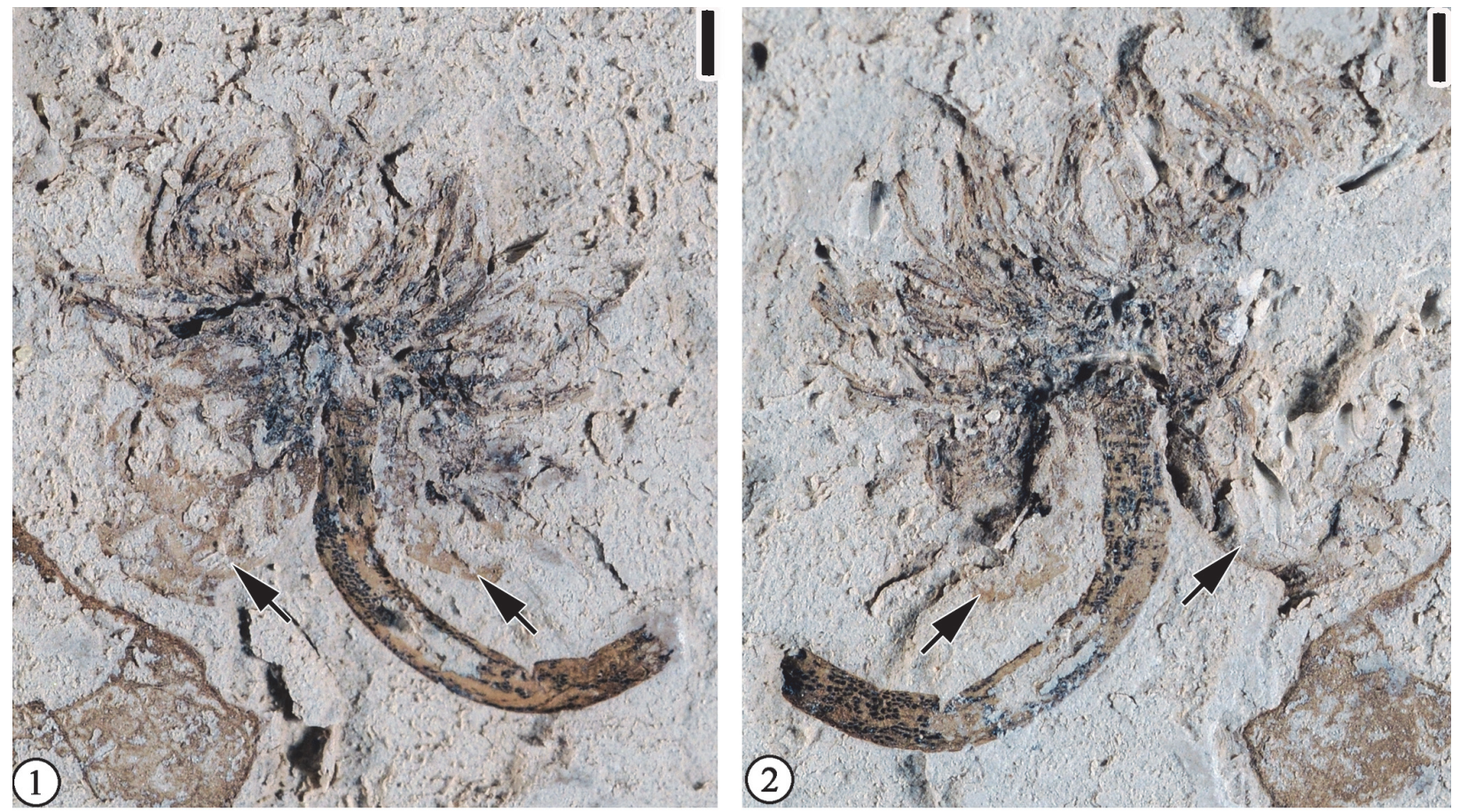

FIGURE 46. Claiborne Floral Type 28: 1, 2) CONN-Q06-11, Q06-11' , part and counterpart of a flower showing filaments, perianth parts (indicated by arrows), and pedicel. All scale bars equal $1 \mathrm{~mm}$.
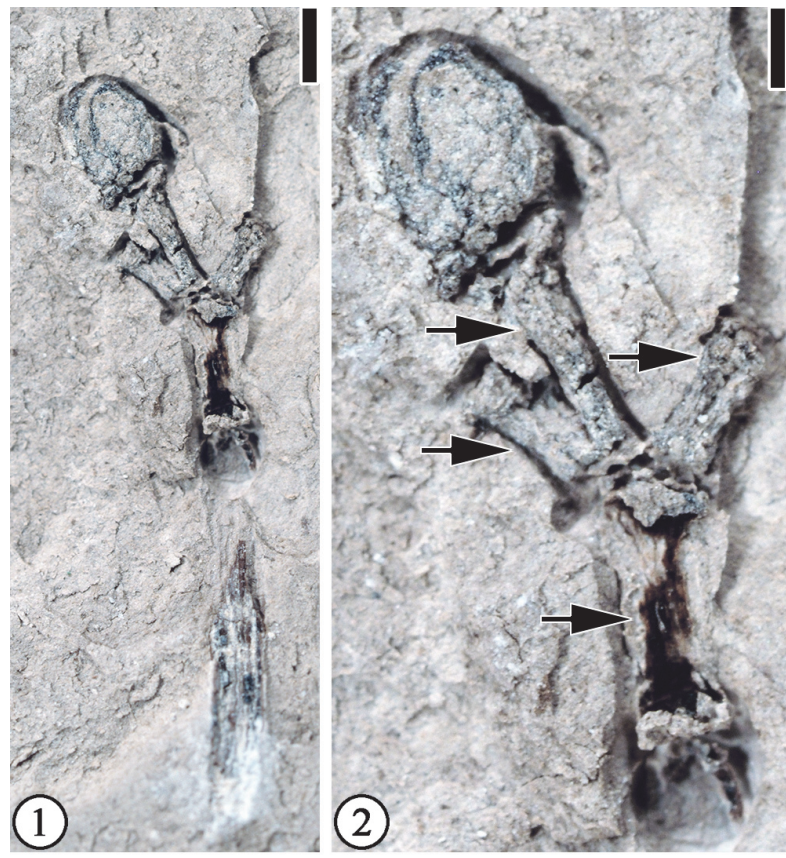

FIGURE 47. Claiborne Inflorescence Type 1: 1) UF15820-043613, showing umbellate inflorescence. Scale bar equals $1 \mathrm{~mm}$; 2) Enlargement of Figure 47.1 to show four floral parts (indicated by arrows), two with floral buds attached and two with only pedicel attached. Note the 4th pedicel and floral bud are superimposed over the peduncle. Scale bar equals $0.5 \mathrm{~mm}$.
Description. Umbellate inflorescence laterally compressed, bearing four pedicels and one floral bud; peduncle $11 \mathrm{~mm}$ long and $0.7 \mathrm{~mm}$ wide; floral bud elliptic, $1.5-3 \mathrm{~mm}$ long and $1-1.5 \mathrm{~mm}$ wide; at least two perianth parts present on the floral bud; pedicel length variable, $1-1.5 \mathrm{~mm}$ long and $0.5 \mathrm{~mm}$ wide.

Number of specimens examined. 1. UF15820043613.

Remarks. The morphology of this inflorescence type is unique in that it is umbellate. This inflorescence type has only been recovered from the Puryear locality to date.

\section{Angiosperm Incertae Sedis - Infructescences \\ Claiborne Infructescence Type 1 Figure 48}

Description. Elongate infructescence $2 \mathrm{~cm}$ long and $1 \mathrm{~cm}$ wide with ca. 15 helically arranged fruits. Individual fruits ca. $3 \mathrm{~mm}$ in diameter.

Number of specimens examined. 1. UF15820059475.

Remarks. A pedicel is not observed on the Puryear specimen. Wang et al. (2013) described 15 specimens from the Warman clay pit, Tennessee. The cuticle of each fruit appears wrinkled, as in the Warman specimens. Table 5 compares the 14 


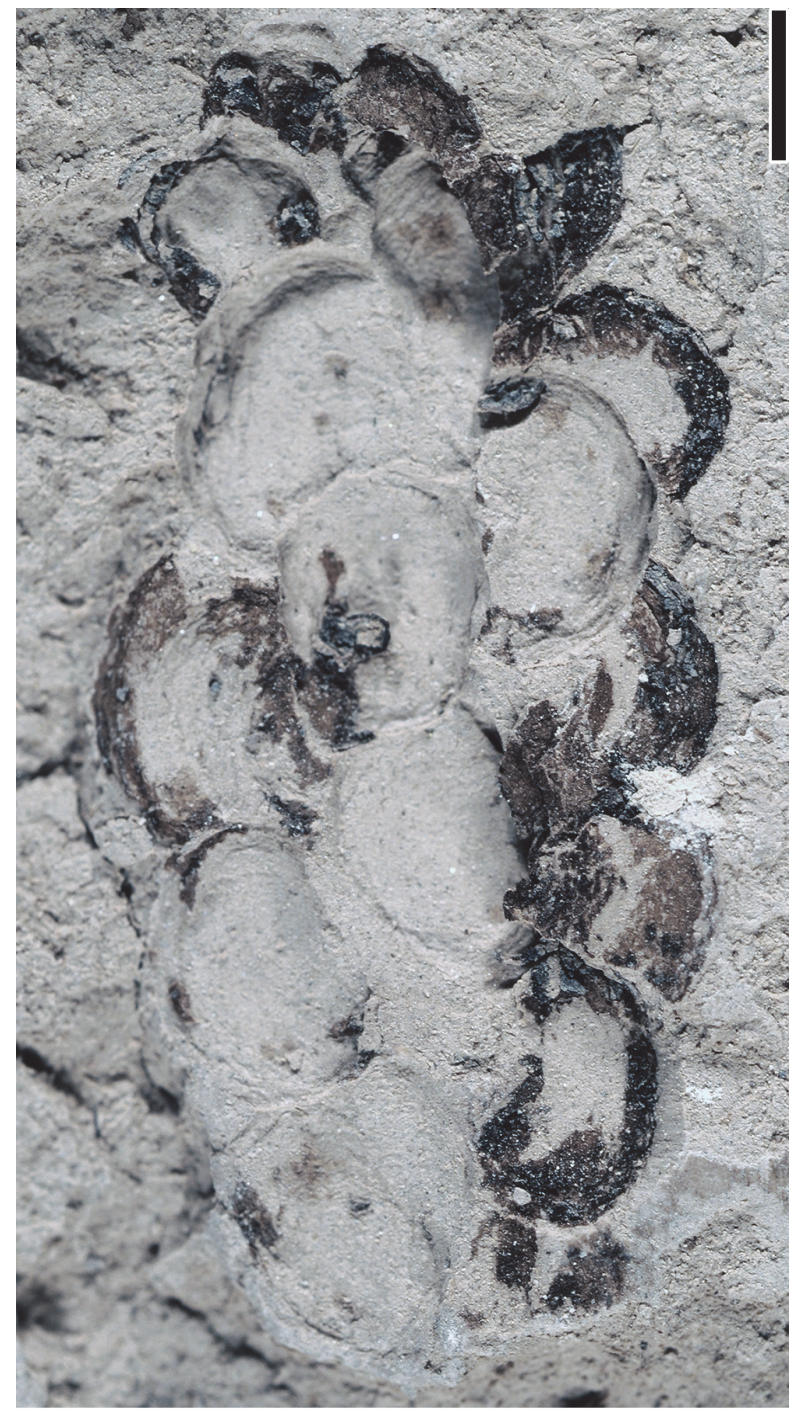

FIGURE 48. Claiborne Infructescence Type 1: UF15820-059475, infructescence with helically arranged fruits. Scale bar equals $2 \mathrm{~mm}$.

infructescence types in the ANGIOSPERM INCERTAE SEDIS category.

\section{Claiborne Infructescence Type 8}

Figure 49

Description. Infructescence paniculate; panicle determinate, with at least 5 branches attached on

TABLE 5. Comparison of major characters of the Claiborne infructescence types. All dimensions are in millimeters (mm). "?" indicates that a measurement is not available or a character is not observed. Available as spreadsheet file for download at https://palaeo-electronica.org/content/2020/3177-fossil-plants-from-tennessee. the main axis ca. $38 \mathrm{~mm}$ long and $1 \mathrm{~mm}$ wide; peduncle of each branch varying from 4 to $10 \mathrm{~mm}$ long and ca. $0.5 \mathrm{~mm}$ wide; each branch bearing two lateral, pedicellate fruits and 1 central, sessile fruit; immature fruits with at least three perianth parts; pedicel length 1.5 to $4 \mathrm{~mm}$ long and $0.5 \mathrm{~mm}$ wide. Fruits wide ovate, $3-4 \mathrm{~mm}$ long and $2-3 \mathrm{~mm}$ wide; style persistent, one on each fruit, $1-1.5 \mathrm{~mm}$ long and ca. $0.3 \mathrm{~mm}$ wide.

Number of specimens examined. 3. UF15820059392, 059393, 059395.

Remarks. Figure 49.3-4 shows that one middle fruit and one lateral fruit still have perianth parts attached, probably representing an early stage of fruit development. The middle fruit is always larger supporting the hypothesis that this is a determinate panicle.

\section{Claiborne Infructescence Type 9 Figure 50}

Description. Infructescence racemose; unbranched peduncle (axis) at least $12 \mathrm{~mm}$ long and $0.5 \mathrm{~mm}$ wide, bearing 10 alternately arranged, pedicellate fruiting structures; mature fruiting structures detached with only pedicel scars (bases?) left on the peduncle as protrusions; fruiting structure 3-7 $\mathrm{mm}$ long and ca. 3-4 $\mathrm{mm}$ wide, enclosed by numerous spines; pedicel $2 \mathrm{~mm}$ long and $0.5 \mathrm{~mm}$ wide.

Number of specimens examined. 1. UF15820059394.

Remarks. In gross morphology, the fruiting structure of this infructescence is similar to the fibrous fruits described from the Lamkin clay pit, Kentucky (UF15815) by Grote (1989, pp. 172-174, pl. VIII, figures 1-8). They differ in that (1) the fibrous fruits from Lamkin possess thin fibers instead of spines and (2) the bases of the fibrous fruits from Lamkin are not decurrent, indicating the absence of the pedicels. Due to the poor preservation, it is difficult to tell if each fruiting structure of the Puryear specimen represents one or multiple fruits and for the same reason, the spines may be bracts or remnant perianth.

\section{Claiborne Infructescence Type 10 Figure 51}

Description. Infructescence spherical, ca. 5-8 mm in diameter. Peduncle $6-10 \mathrm{~mm}$ long and 1-1.3 $\mathrm{mm}$ wide, with smooth surface. Individual fruits sessile, at least 20 , each ca. $1 \mathrm{~mm}$ long and 0.5 $\mathrm{mm}$ wide, apex rounded or truncate.

Number of specimens examined. 8. UF15820059472; 061124. 


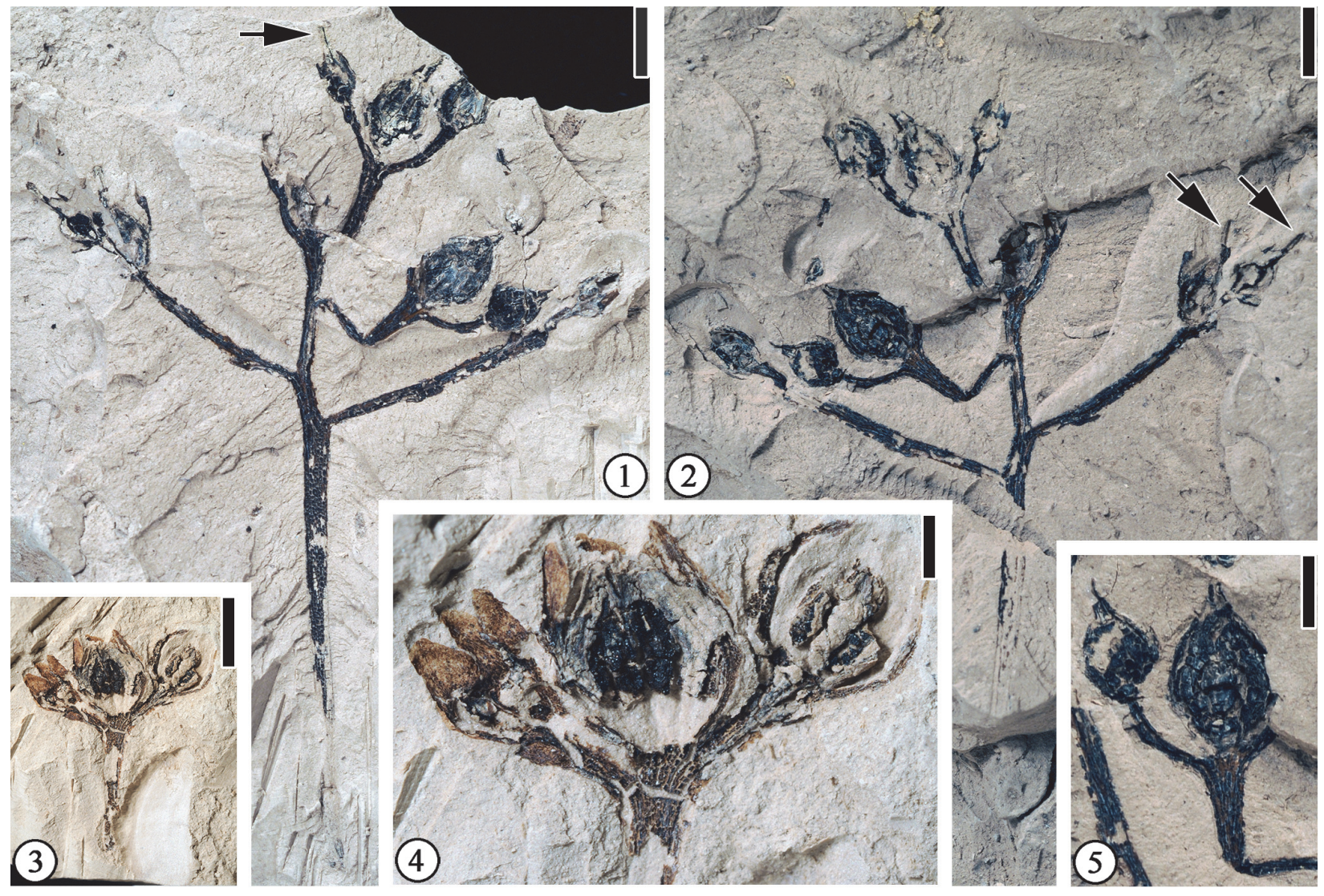

FIGURE 49. Claiborne Infructescence Type 8: 1, 2) UF15820-059392, 059392', part and counterpart of specimen showing paniculate infructescence. Note persistent styles (indicated by arrows); 3) UF15820-059393, specimen showing two lateral pedicellate fruits and one middle sessile fruit. Note perianth parts on two fruits on the left; 4) Enlargement of Figure 49.3 to show perianth parts. Note the middle sessile fruit and two lateral pedicellate fruits, and their size differences. Note three perianth parts of the lateral fruit on the left. Scale bar equals $1 \mathrm{~mm}$; 5) Enlargement of Figure 49.2 to show the middle, sessile fruit and one lateral pedicellate fruit. Note their size difference. All scale bars equal 3 $\mathrm{mm}$ except in Figure 49.4, which equals $1 \mathrm{~mm}$, and in Figure 49.5, which equals $2 \mathrm{~mm}$.

Remarks. Wang et al. (2013, pp. 56-67, figure 49) described two specimens from the Warman clay pit, Tennessee and assigned them to "Sparganium" $\mathrm{sp}$. The specimens from the Puryear locality are similar to those from the Warman locality in size and shape. However, they differ in that (1) individual fruits of the Puryear infructescence have rounded or truncate apices and (2) the peduncles lack trichomes. Based on these differences we assign the Puryear specimens to a different infructescence type.

\section{Claiborne Infructescence Type 11}

Figure 52

Description. Laterally preserved infructescence with two pedicellate, elongate ovate/elliptical fruits ca. $14-18 \mathrm{~mm}$ long and $5-10 \mathrm{~mm}$ wide, tapering to an acute apex. Longitudinal grooves/ridges visible. Pedicel thin, ca. $7 \mathrm{~mm}$ long and $0.5 \mathrm{~mm}$ wide.
Number of specimens examined. 4. UF15820059400, 061140.

Remarks. Compared with Claiborne Infructescence Type 12 (Table 5), the pedicel of this infructescence type is shorter and the fruit size is smaller.

\section{Claiborne Infructescence Type 12}

Figure 53

Description. Branched axis ca. $1 \mathrm{~mm}$ wide bearing three elliptical/obovate fruits. Fruit obovate, ca. 6-9 mm long and 4-6 mm wide. Pedicel at least 15 $\mathrm{mm}$ long and $0.5 \mathrm{~mm}$ wide.

Number of specimens examined. 1. UF15820061143.

Remarks. These fruits look like undehisced capsules. They differ from Claiborne Infructescence Type 11 in having longer pedicels, smaller fruits, 

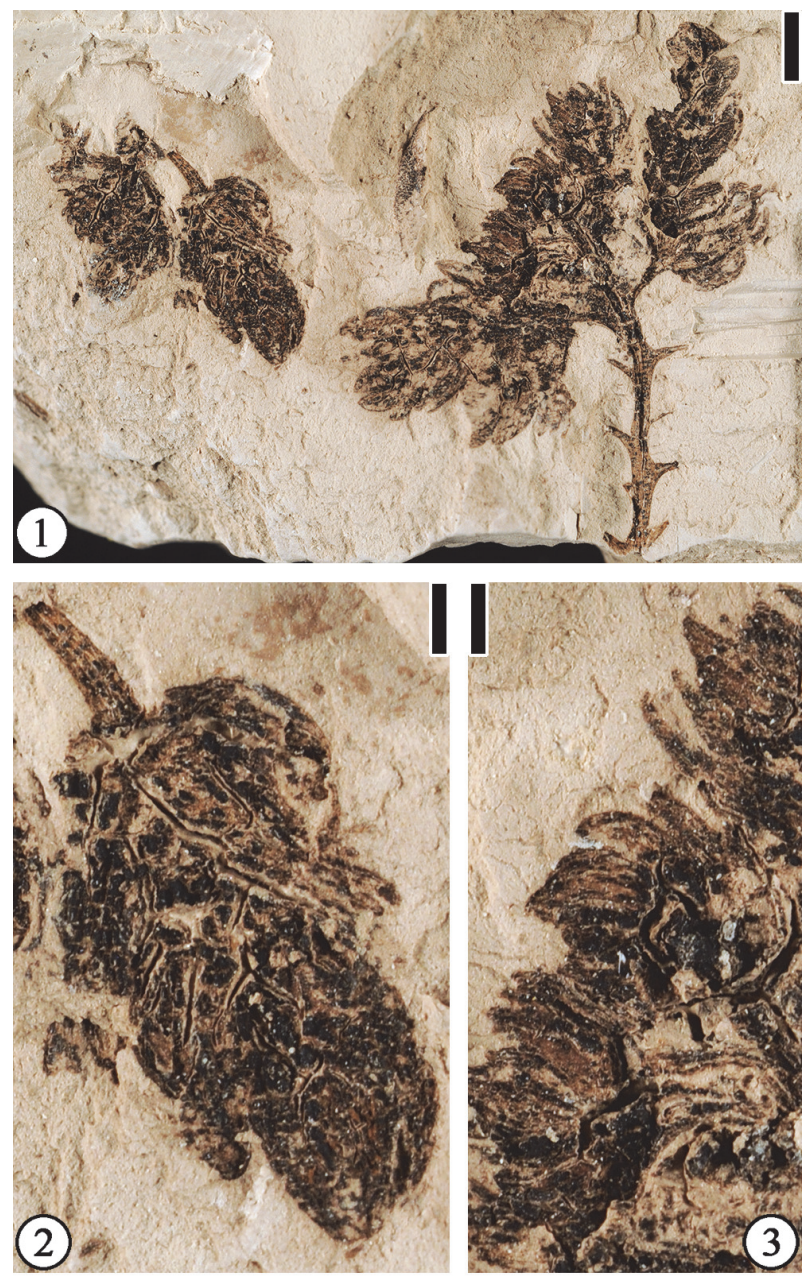

FIGURE 50. Claiborne Infructescence Type 9: 1) UF15820-059394, specimen showing an incomplete infructescence and two dispersed fruiting structures. Note at least eight protrusions, probably representing the bases of pedicels, present on the peduncle. Scale bar equals $3 \mathrm{~mm}$; 2) Enlargement of Figure 50.1. Scale bar equals $1 \mathrm{~mm}$; 3) Enlargement of Figure 50.1 to show spines on the fruiting structures. Scale bar equals $1 \mathrm{~mm}$.

and in lacking the obvious longitudinal grooves/ ridges (Table 5).

\section{Claiborne Infructescence Type 13}

Figure 54

Description. Vertically preserved infructescence with three globose fruits; each fruit ca. $1 \mathrm{~cm}$ in diameter, attached to a peduncle ca. $2 \mathrm{~mm}$ in diameter.

Number of specimens examined. 1. UF15820043602, 043602'.

Remarks. It is not known if pedicels are present or how the fruits are attached to the peduncle. If the pedicels are present, they probably are very short.
The peduncle is indicated by a depression in Figure 54.2.

The shape of this infructescence is similar to that of Lobataticarpum variabile Reid and Chandler (1933, p. 314, pl. 14, figures 18-19), with three- or four-lobed syncarpous fruits that have questionable affinities with the Anacardiaceae. However, the specimen from Puryear represents an infructescence with possibly three single-seeded fruits.

\section{Claiborne Infructescence Type 14 Figure 55}

Description. Spherical infructescence $5-6 \mathrm{~mm}$ in diameter, with 10 sessile fruits attached to a peduncle ca. $12 \mathrm{~mm}$ long and $0.5 \mathrm{~mm}$ wide. Each fruit ca. $1.5 \mathrm{~mm}$ long and $1 \mathrm{~mm}$ wide, with truncate apex.

Number of specimens examined. 1. CONN-R101.

Remarks. This infructescence is similar to Claiborne Infructescence Type 10 in that both are spherical with sessile fruits (Table 5). They differ in that Claiborne Infructescence Type 14 has smaller infructescence size, longer and slenderer peduncle, and fewer fruits.

\section{Angiosperm Insertae Sedis - Fruits and Seeds \\ Genus CARPOLITHUS Linnaeus, 1768 Carpolithus prangosoides Berry, 1916 \\ Figure 56}

1916 Carpolithus prangosoides Berry, p. 351, pl. 104, fig. 9.

1916 Carpolithus henryensis Berry, p. 352, pl. 112, fig. 16.

1926 Terminalia vera Berry, p. 61, figs. 1-5.

1930 Terminalia vera Berry, pp.119-122, pl. 49, figs. 21-27.

2013 Carpolithus prangosoides Berry; Wang, Blanchard, and Dilcher, p. 50, fig. 43.

Description. Fruit elliptic, with five longitudinally attached lateral wings; wing venation reticulate. Seed body narrowly elliptic with longitudinal striations and a strong middle ridge.

Number of specimens examined. 6. UF15820048318, 048319, 059459, 059471.

Remarks. O'Leary (2007) and Wang et al. (2013) summarized the nomenclatural history of Carpolithus prangosoides Berry, a common winged fruit from the Claiborne Group in Tennessee and Kentucky. The Puryear specimens show some variation of fruit size, from $1.5 \mathrm{~cm}$ to $3 \mathrm{~cm}$ long and from $7 \mathrm{~mm}$ to $14 \mathrm{~mm}$ wide. As O'Leary (2007) noted, none of the specimens observed show the preservation of the pedicel, indicating that the fruits were 

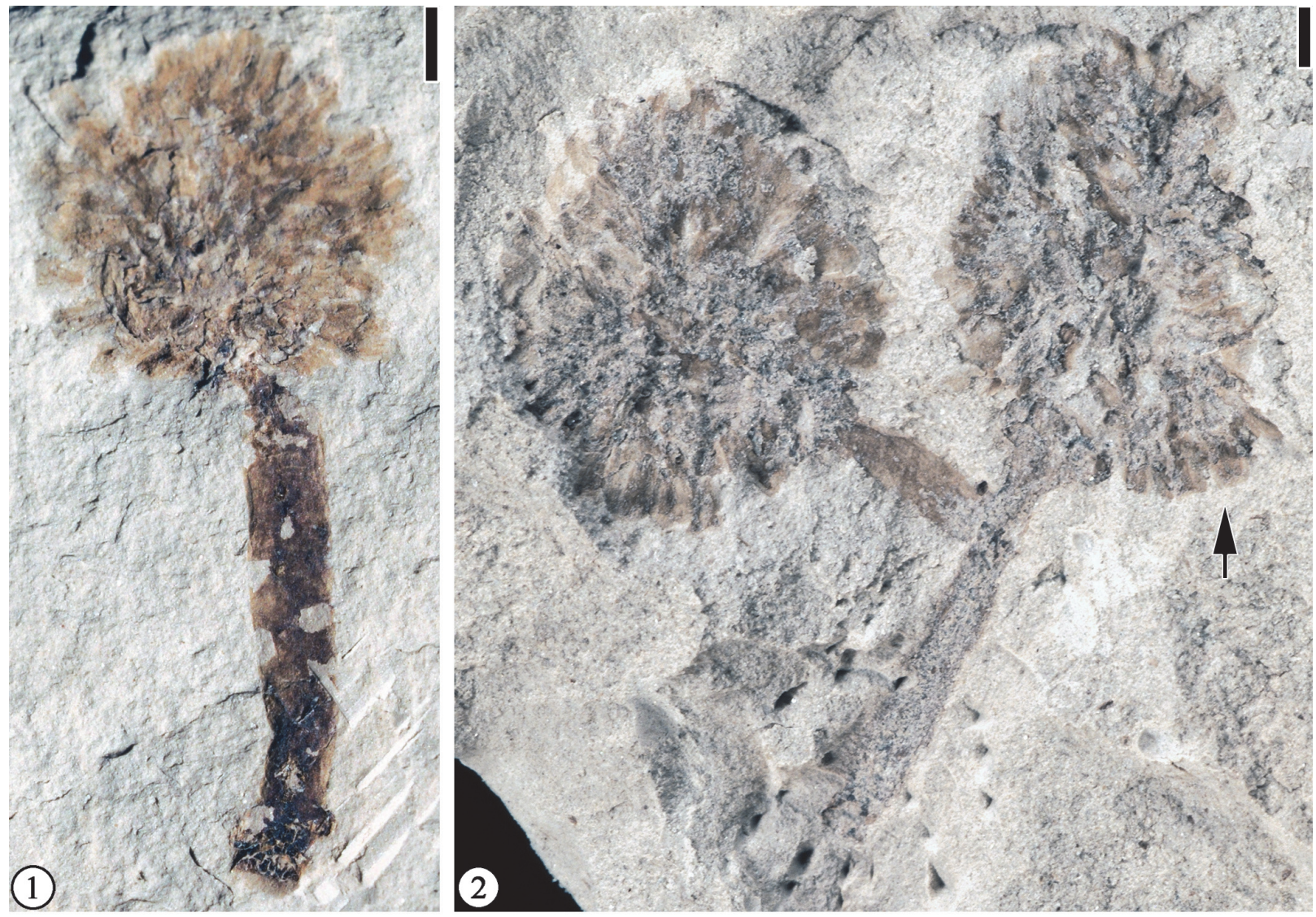

FIGURE 51. Claiborne Infructescence Type 10: 1) UF15820-059472, specimen showing an infructescence; 2) UF15820-061124, showing two superimposed infructescences. Note individual fruits with rounded or truncate apices (indicated by arrow). All scale bars equal $1 \mathrm{~mm}$.

probably sessile or that they were shed by abscising from the distal end of the pedicel. The strong middle ridge probably indicates the attachment scar of a fruit wing.

One specimen (Figure 56.3, 5; UF15820059471) from the Puryear locality shows that at least six small, probably immature, winged fruits are similar to other specimens of Carpolithus prangosoides in appearance. They all have an elliptic fruit body with longitudinally attached wings but are much smaller compared with other $C$. prangosoides specimens $(5 \mathrm{~mm}$ long and $1.8 \mathrm{~mm}$ wide vs. $1.5 \mathrm{~cm}$ to $3 \mathrm{~cm}$ long and from $7 \mathrm{~mm}$ to $14 \mathrm{~mm}$ wide). The number of wings of each fruit is unknown due to the preservation. The bases of these fruits are not observed. However, their orientation seems to indicate that they are borne on an axis (or a peduncle) of an infructescence. We illustrate this specimen here and temporarily assign it to $C$. prangosoides. It would be significant if indeed future collection can confirm this assignment since it is unknown if these are simple fruits or they are attached on a peduncle to form an infructescence.
These six fruits on this specimen differ from the fruits of Claiborne Infructescence Type 5 (Blanchard et al., 2016, pp. 41-42, figure 44) in their larger size $(5 \mathrm{~mm}$ long and $1.8 \mathrm{~mm}$ wide vs 2 $\mathrm{mm}$ long and $1 \mathrm{~mm}$ wide) and shape (elliptic vs crescent) (Table 5).

Another specimen (Figure 56.7-9; UF15820059459), a laterally compressed floral structure ca. $1.1 \mathrm{~cm}$ long and $0.8 \mathrm{~cm}$ wide at the distal end, shows five (?) outer perianth parts (wings?) attached to the fruit body. The incomplete pedicel is ca. $2.5 \mathrm{~mm}$ long and $0.7 \mathrm{~mm}$ wide. This specimen is similar to the winged fruits of Carpolithus prangosoides. However, all other specimens of Carpolithus prangosoides that we have examined do not have pedicels preserved or observed. Since this specimen is not well-preserved, and it shows similarity to $C$. prangosoides in having possible fruit wings, we illustrate it here simply for comparison. However, there are not enough characters for us to assign it to C. prangosoides or to establish a new morphotype. 

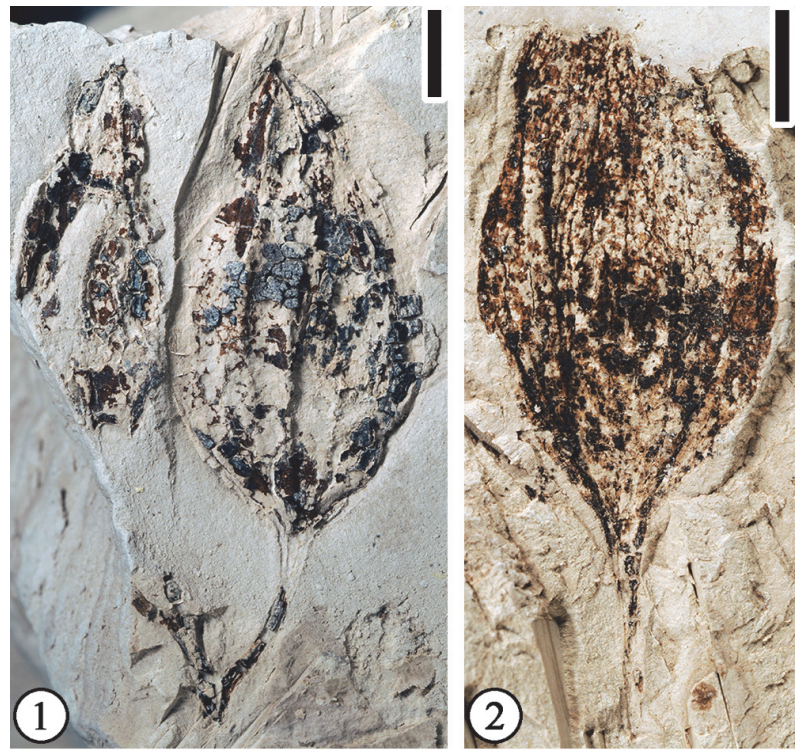

FIGURE 52. Claiborne Infructescence Type 11: 1) UF15820-059400, infructescence with two fruits; 2) UF15820-061140, a dispersed fruit with a decurrent base and a pedicel. All scale bars equal $3 \mathrm{~mm}$.

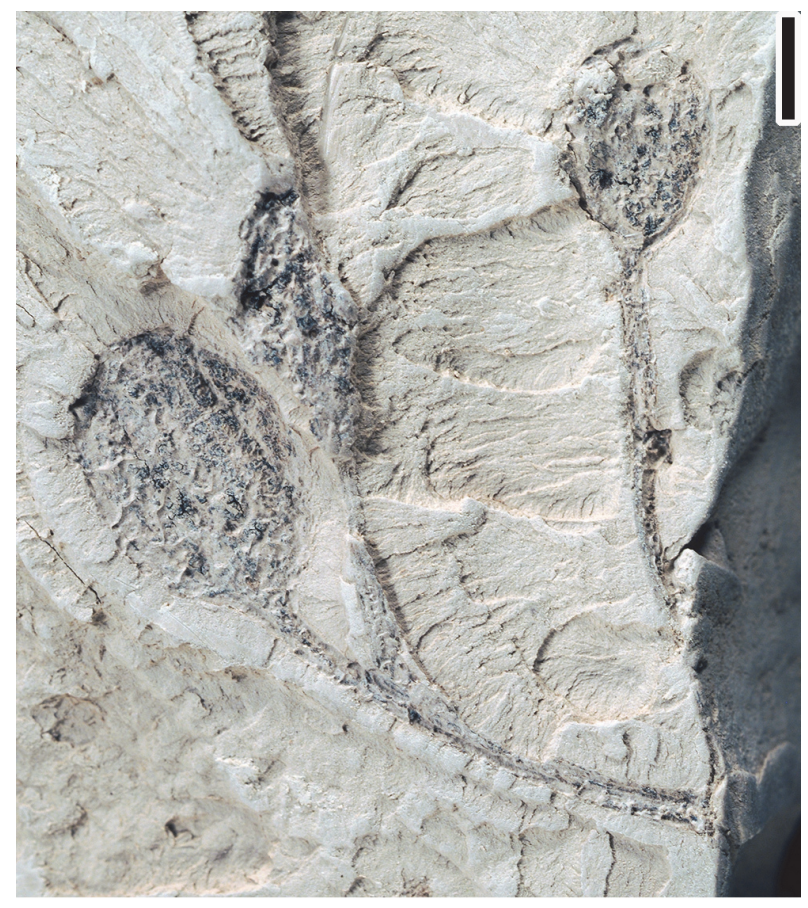

FIGURE 53. Claiborne Infructescence Type 12: UF15820-061143, a branched axis bearing three elliptical/obovate fruits. Scale bar equals $3 \mathrm{~mm}$.
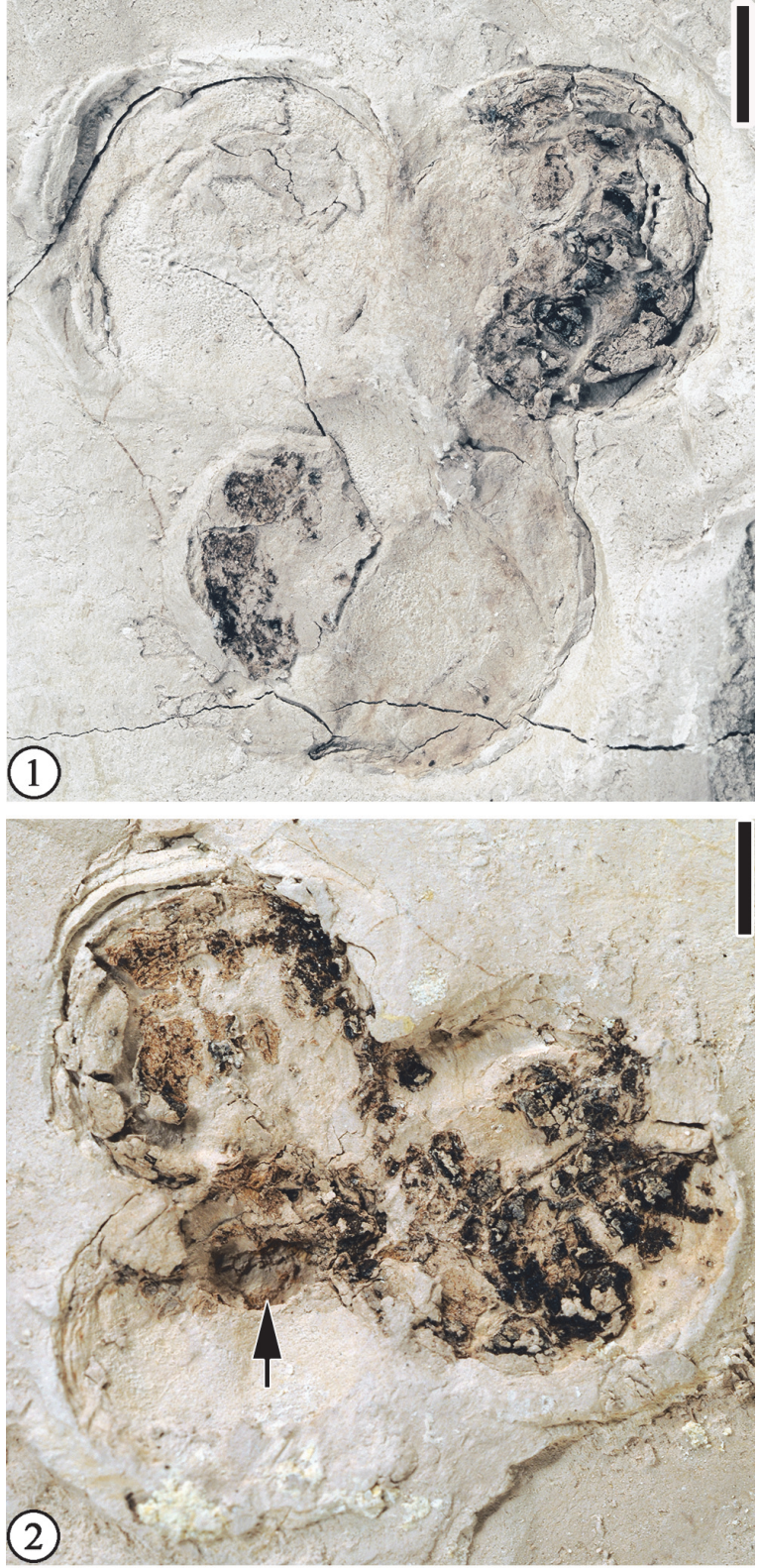

FIGURE 54. Claiborne Infructescence Type 13: 1, 2) UF15820-043602, 043602', vertically preserved infructescence with three globose fruits. Arrow in Figure 54.2 indicates a depression, suggesting the presence of a peduncle. All scale bars equal $3 \mathrm{~mm}$.

Carpolithus warmanensis Wang, Blanchard and Dilcher 2013

Figure 57

Description. Fruit suborbiculate, $10 \mathrm{~mm}$ long and $5.5 \mathrm{~mm}$ wide; seed $6.5 \mathrm{~mm}$ long and $4 \mathrm{~mm}$ wide. Spines present, ca. $1 \mathrm{~mm}$ long.

Number of specimens examined. 2. 15826051471, CONN-Q7-01. 


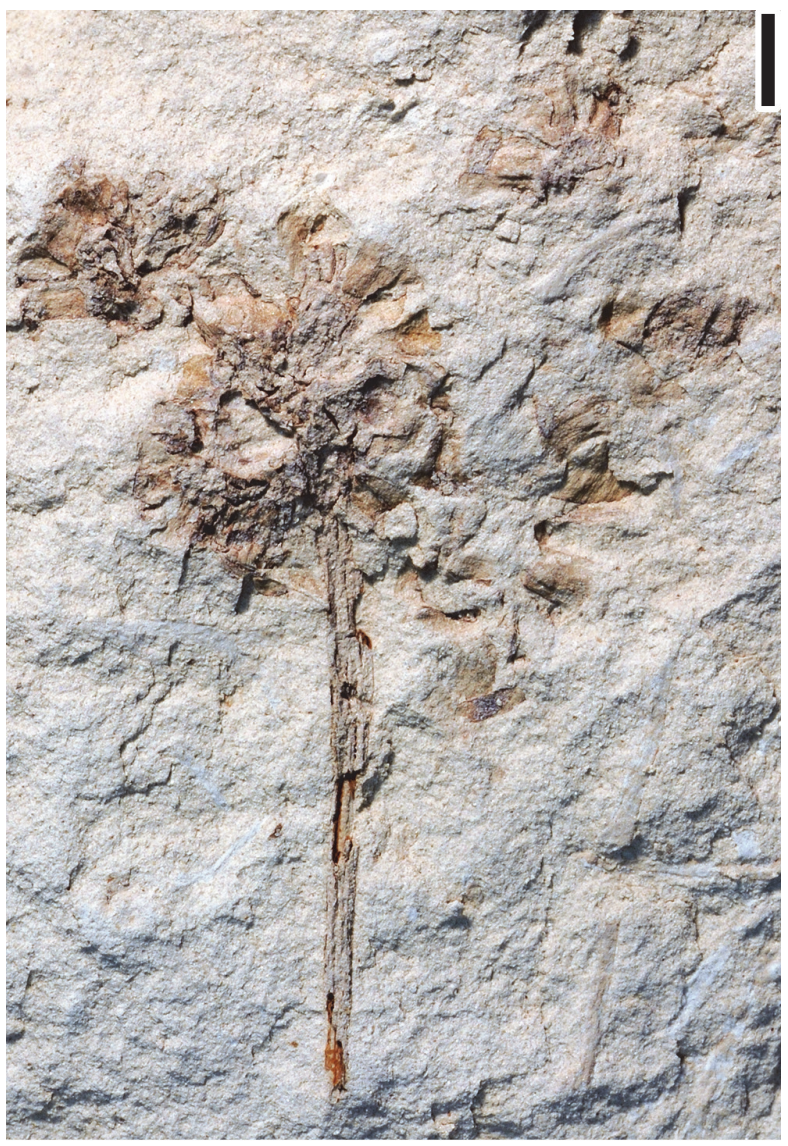

FIGURE 55. Claiborne Infructescence Type 14: CONNR1-01, specimen showing at least four infructescences. The one in the middle has a long peduncle attached. Scale bar equals $3 \mathrm{~mm}$.

FIGURE 56. Carpolithus prangosoides Berry, 1916: 1) UF15820-048318, a large fruit with elliptic fruit body and three wings (indicated by arrows). Scale bar equals 4 $\mathrm{mm}$; 2) Enlargement of Figure 56.1 to show reticulate venation of the fruit wing. Scale bar equals $1 \mathrm{~mm}$; 3 ) UF15820-059471', seven immature, elliptic fruits about $5 \mathrm{~mm}$ long and $1.8 \mathrm{~mm}$ wide. Note that two fruits on the left and two fruits at the lower right overlap. Scale bar equals $3 \mathrm{~mm}$; 4) UF15820-048319, a fruit with rounded wing apices. Scale bar equals $4 \mathrm{~mm}$; 5) Enlargement of two fruits in Figure 56.3 to show thin fruit wing (indicated by lower right arrow) and fruit body (dark area indicated by upper left arrow). Scale bar equals $1 \mathrm{~mm}$; 6) Enlargement of distal part of fruit in Figure 56.4 to show at least four wings (indicated by arrows). Scale bar equals 1 $\mathrm{mm}$; 7) UF15820-059459, a laterally compressed floral structure with attached pedicel. Scale bar equals $2 \mathrm{~mm}$; 8) Enlargement of the apical portion of Figure 56.7 to show the light-colored perianth parts (indicated by arrow) and enclosed darker structure. Scale bar equals $1 \mathrm{~mm}$; 9) Enlargement of the basal portion of Figure 56.7 to show the pedicel (indicated by arrow). Scale bar equals $1 \mathrm{~mm}$.
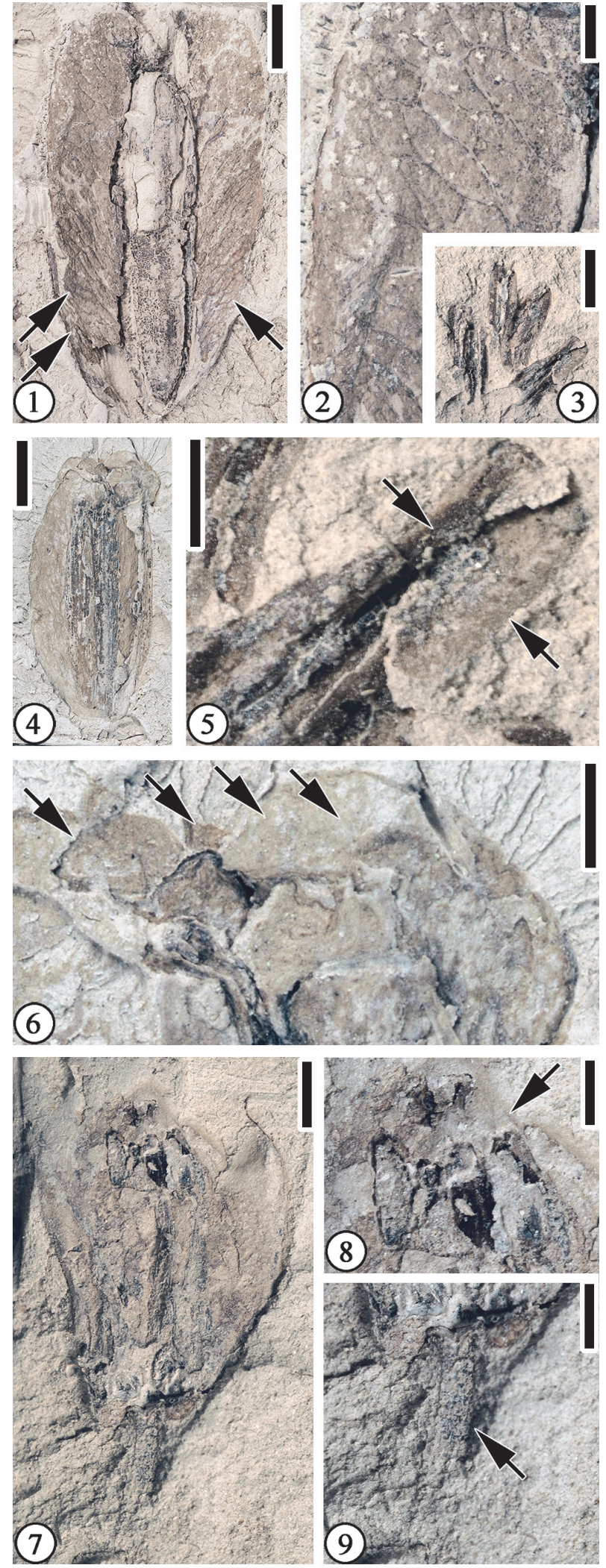

FIGURE 56 caption to left. 

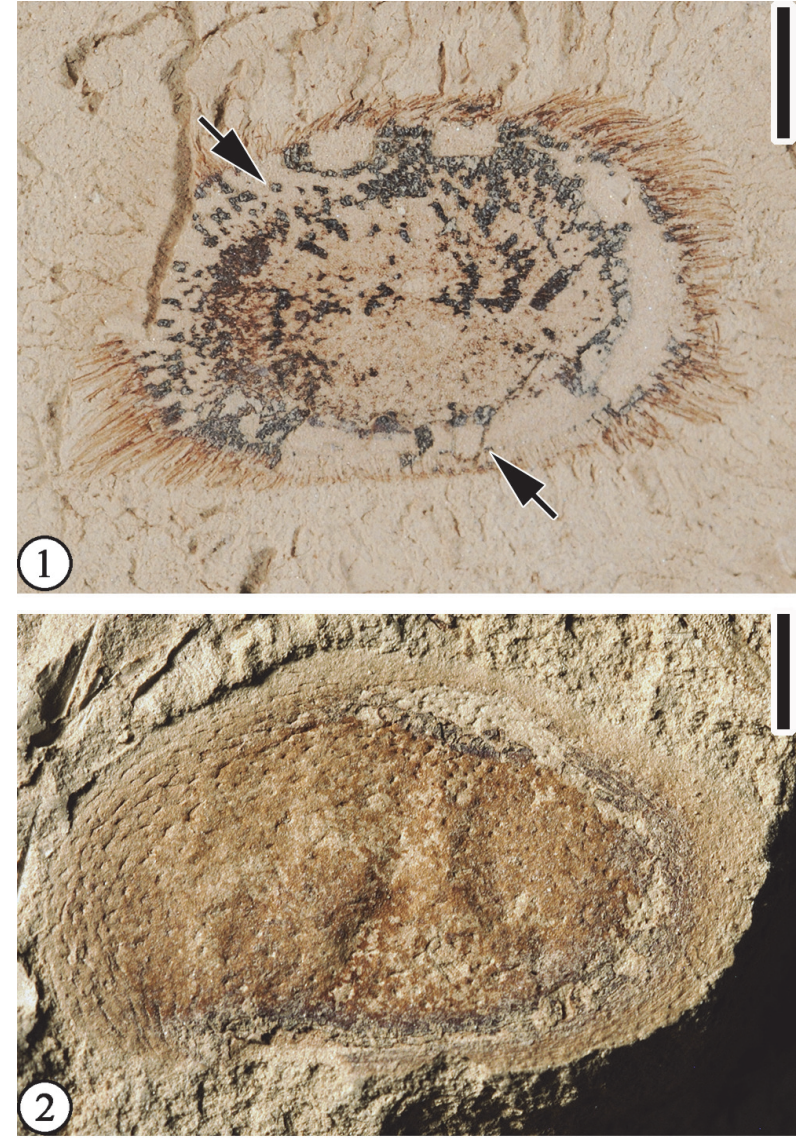

FIGURE 57. Carpolithus warmanensis Wang, Blanchard and Dilcher, 2013: 1) CONN-Q7-01, suborbiculate fruit with spines. Note a zone ca. $1 \mathrm{~mm}$ thick (indicated by arrows) surrounding the seed; 2) 15826-051471, reniform fruit from the Warman clay pit. All scale bars equal $2 \mathrm{~mm}$.

Remarks. Wang et al. (2013, p. 52, figure 45; Figure 57.2) reported one specimen from the Warman clay pit, Tennessee, which only have impressions of spine bases preserved on the fruit body. The specimen from Puryear shows well-preserved spines on the fruit. The seed is defined by a surrounding zone about $1 \mathrm{~mm}$ thick, which may represent the mesocarp of the fruit.

Genus PALMOCARPON Berry 1930 Palmocarpon wilcoxiana (Berry) Wang, Blanchard and Dilcher 2013

Figure 58

Description. See Wang et al. (2013, pp. 54-55, figures 47,48$)$ and Blanchard et al. (2016, p. 51, figure 55).

Number of specimens examined. 6. UF15820007246, 059470, 043616, 059402.

Remarks. The specimens from the Puryear clay pit show size variations from 1 to $2.8 \mathrm{~cm}$ long. For
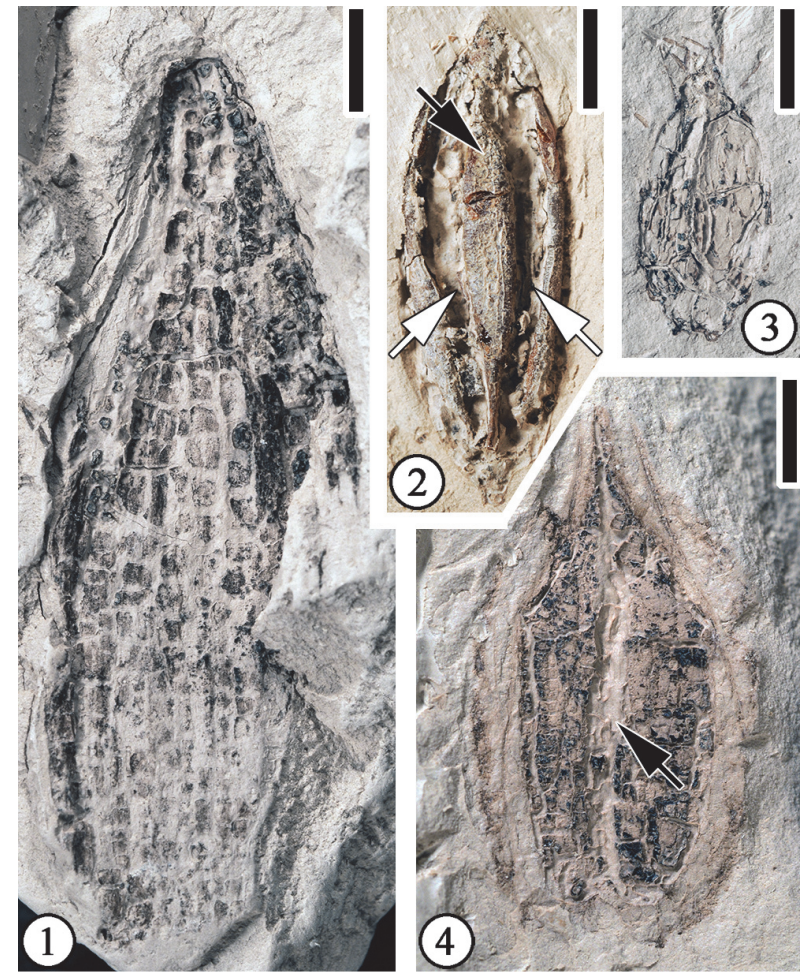

FIGURE 58. Palmocarpon wilcoxiana (Berry) Wang, Blanchard, and Dilcher, 2013: 1) UF15820-043616, a large endocarp ca. $29 \mathrm{~mm}$ long and $10 \mathrm{~mm}$ wide; 2) UF15820-059402, an endocarp with a middle ridge (indicated by the black arrow) and two grooves (indicated by the two white arrows); 3) UF15820-059470, a small endocarp; 4) UF15820-007246, an endocarp with a middle groove (indicated by arrow). All scale bars equal 3 $\mathrm{mm}$.

example, one endocarp (UF15820-043616; Figure 58.1 ) is $2.8 \mathrm{~cm}$ long and is larger than any specimens described from the Warman clay pit, Tennessee (1.5-2.5 cm long; Wang et al., 2013) and the Bovay clay pit, Mississippi (1.2-2.3 cm long; Blanchard et al., 2016). The specimens from the Puryear clay pit show a wider variation in size than those from the Warman or Bovay clay pits. The Puryear specimens include both the smallest and largest specimens of Palmocarpon wilcoxiana we have examined.

Lesquereux (1878; p. 119) established the fossil genus Palmocarpon for dispersed fruits from the Eocene strata in Colorado and New Mexico, with the following diagnosis: "Fruits of various size and forms, generally surrounded by a shelly pericarp, and found in connection with remains of palms." These fruits co-occur with fragments of palm leaves in the same horizon. Therefore, Lesquereux (1878, pp.108-109) assigned this fossil 


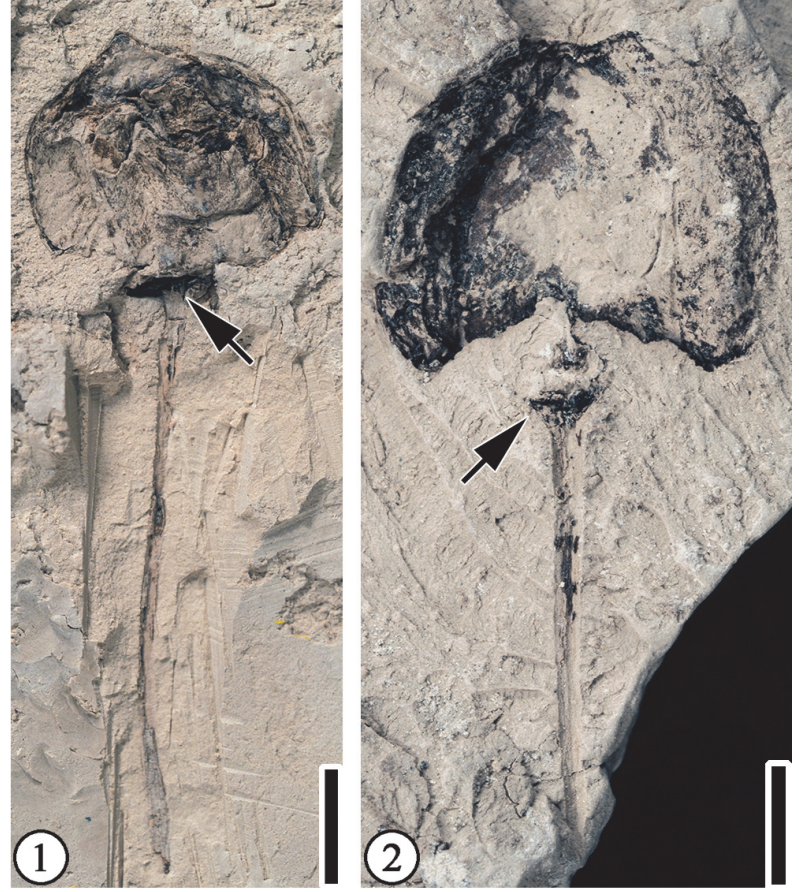

FIGURE 59. "Ficus" fructus pedicellata Berry, 1930: 1) UF15820- 059484, a smaller fruit with an attenuate apex, a receptacle (indicated by arrow) and a long pedicel; 2) UF15820-061125, a larger fruit with a receptacle (indicated by arrow) and an incomplete pedicel. All scale bars equal $3 \mathrm{~mm}$.

genus to the Palmae, although he did not specify which characters he used to associate these fruits with the family.

Berry (1916; p. 331, pl. 99, figs. 5-7; p. 332, pl. 99, fig. 8.) first described four impression specimens from the Puryear clay pit, Tennessee, and assigned three to Nyssa wilcoxiana and one to Nyssa eolignitica. In his following publications, Berry assigned similar specimens to Nyssa wilcoxiana (Berry, 1924, 1930, 1941) and two other specimens to Palmocarpon syagrusioides (Berry, 1930). These specimens may represent different preservation modes of the same fruit/seed type at various developmental stages. We propose that they all belong to the same fossil-genus Palmocarpon but available characters do not warrant their assignment to the genus Nyssa or the Palmae. We retain the species epithet wilcoxiana proposed by Berry (1916).

"Ficus" fructus pedicellata Berry, 1930 Figure 59

1930 "Ficus" fructus pedicellata Berry, p. 66, pl. 48, fig. 8.
Description. Pedicellate fruit ca. $7.5-10 \mathrm{~mm}$ wide and 7-10 mm high; Apex attenuate. Pedicel ca. 2.5 $\mathrm{cm}$ long and $0.5 \mathrm{~mm}$ wide; receptacle ca. $2 \mathrm{~mm}$ in diameter.

Number of specimens examined. 2. UF15820059484, 061125.

Remarks. Berry (1930, p. 66, pl. 48, figure 8) described one specimen from the Puryear locality and assigned it to a fossil species in the extant genus Ficus. It is larger ( $8 \mathrm{~mm}$ long and up to 10 $\mathrm{mm}$ wide) and has two bracts at the base. The surface of Berry's specimens is "minutely tuberculated," whereas the Puryear specimens are not. The attenuate apex may represent a persistent style. We treat these three specimens as the same type and retain Berry's species epithet, but place quotation marks on the generic name to indicate that the assignment of the fossil species to the extant genus is incorrect.

\section{"Ptelea" eocenica Berry, 1930 Figure 60}

\section{Ptelea eocenica Berry, p. 92, pl. 41, fig. 4.}

Description. Fruit a samara, consisting of one or two fusiform endocarps and a wing. The endocarp ca. $3 \mathrm{~mm}$ long and $2 \mathrm{~mm}$ wide. Fruit wing $7 \mathrm{~mm}$ long and $9 \mathrm{~mm}$ wide, with finely reticulate venation; apex rounded. Pedicel slender, ca. $8 \mathrm{~mm}$ long and $0.5-1 \mathrm{~mm}$ wide.

Number of specimens examined. 3. UF15820059403, CONN-Q2-03, CONN-Q3-07.

Remarks. Berry (1930) described a specimen from the Grand Junction locality in Hardeman County, Tennessee and assigned it to Ptelea eocenica. Manchester and O'Leary (2010, pp. 73-75, figure 24a) reexamined Berry's specimen and suggested that the thickness of the pedicel (too thick to be that of Ptelea), perianth scar, fusiform locular area (endocarp), and organization of venation are similar to those of extant fruits of Craigia and Maxwellia and tentatively placed this specimen under fossil Malvaceae. Call and Dilcher (1995) suggested that the affinities of this fruit are best considered unresolved, which we agree with. The fossil resembles fruits of Ptelea in size and shape. However, other features, including the persistent remains of a floral disc at the base of the wing, trinervate venation of the wing, and ellipsoidal endocarp shape, which would confirm its identity as Ptelea, are not evident. The perianth scars of these Puryear specimens, including one specimen described by Berry (1930), are not as obvious as suggested by Manchester and O'Leary (2010). In this report, we follow Call and Dilcher (1995) and treat the affinities of these Puryear fruits as unresolved. 

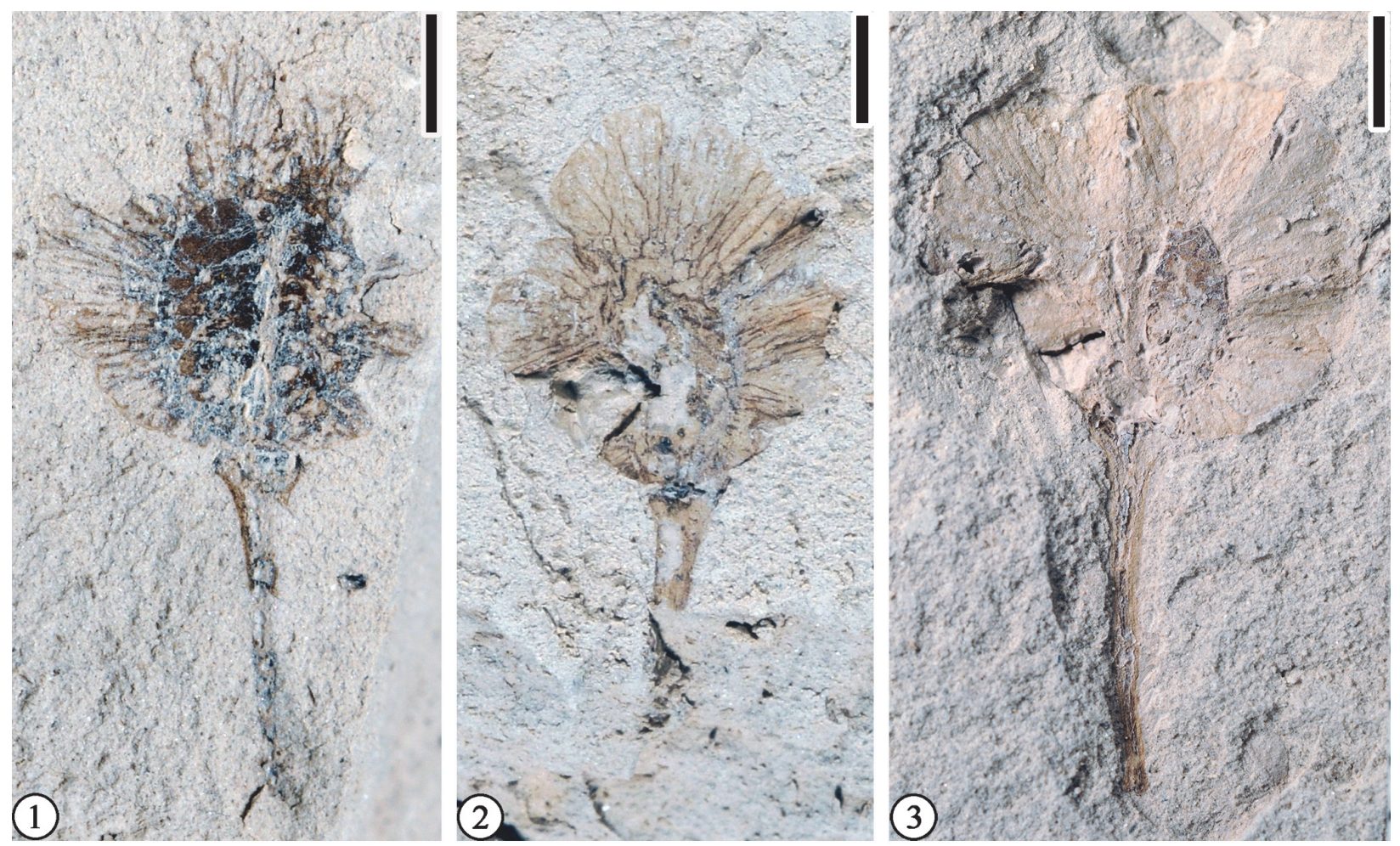

FIGURE 60. "Ptelea" eocenica Berry, 1930: 1) CONN-Q2-03, specimen showing a fruit with two fusiform seeds; 2) CONN-Q3-07, specimen showing reticulate venation of fruit wing; 3) UF15820-059403, specimen showing pedicel, fruit wing, and a fusiform seed. All scale bars equal $2 \mathrm{~mm}$.

\section{Claiborne Fruit/Seed Type 2}

Figure 61

Description. Fruit/fruiting heads laterally compressed, spatulate?, $1.2-1.5 \mathrm{~cm}$ long and $2.0-2.2$ $\mathrm{cm}$ wide, bearing 6-7 apically split appendages 6$11 \mathrm{~mm}$ long and $2-4 \mathrm{~mm}$ wide. A disc-like receptacle present, $20 \mathrm{~mm}$. Peduncle/pedicel stout, $7 \mathrm{~mm}$ long and $4 \mathrm{~mm}$ wide.

Number of specimens examined. 5. UF15820002240, 059485, UF15815-008198, 053095.

Remarks. Wang et al. (2013, pp. 57-58, figure 51) described two specimens from the Warman clay pit, Tennessee. After comparison with specimens with similar morphology from the Miocene flora of the Meuro and Rauno sequences in the Lusatica region (Saxony and Brandenburg, Germany) (Mai 2001, pl. 8, figures 16-24), Wang et al. (2013) suggested that these specimens possibly represent a member of Fagaceae with acorns already dispersed and the appendages probably represent elongate cupular scales. All attached scales seem to be oriented in one direction.

Another possibility is that these specimens, including those from the Warman locality (Wang et al., 2013, pp. 57-58, figure 51), are compressions/ impressions of Cornerocarpon copiosum Grote (Wang et al., 2013, p. 30, figures 22, 23; Figure $61.3,4)$, because of the spatulate fruit/fruiting head with apically split appendages attached on one side of the disc-like receptacle. A major difference is that the appendages of this fruit/seed type (6-11 $\mathrm{mm}$ long and 2-4 $\mathrm{mm}$ wide) are longer than the "tepals" of Cornerocarpon copiosum (ca $6 \mathrm{~mm}$ long and 2.2-5.0 $\mathrm{mm}$ wide)

\section{Claiborne Fruit/Seed Type 6}

Figure 62

Description. Compressed fruit/seed ca. $1.4 \mathrm{~cm}$ in diameter with a reticulate surface pattern. Exterior margin smooth.

Number of specimens examined. 1. UF15820043597.

Remarks. This specimen belongs to the same fruit/seed type from the Bovay locality, Mississippi (Blanchard et al., 2016, figure 50.3), but lacks fibers.

\section{Claiborne Fruit/Seed Type 11 \\ Figure 63}

Description. Disseminule narrowly elliptic, $5 \mathrm{~mm}$ long and $2.5 \mathrm{~mm}$ wide; an apical extension ca. 3 

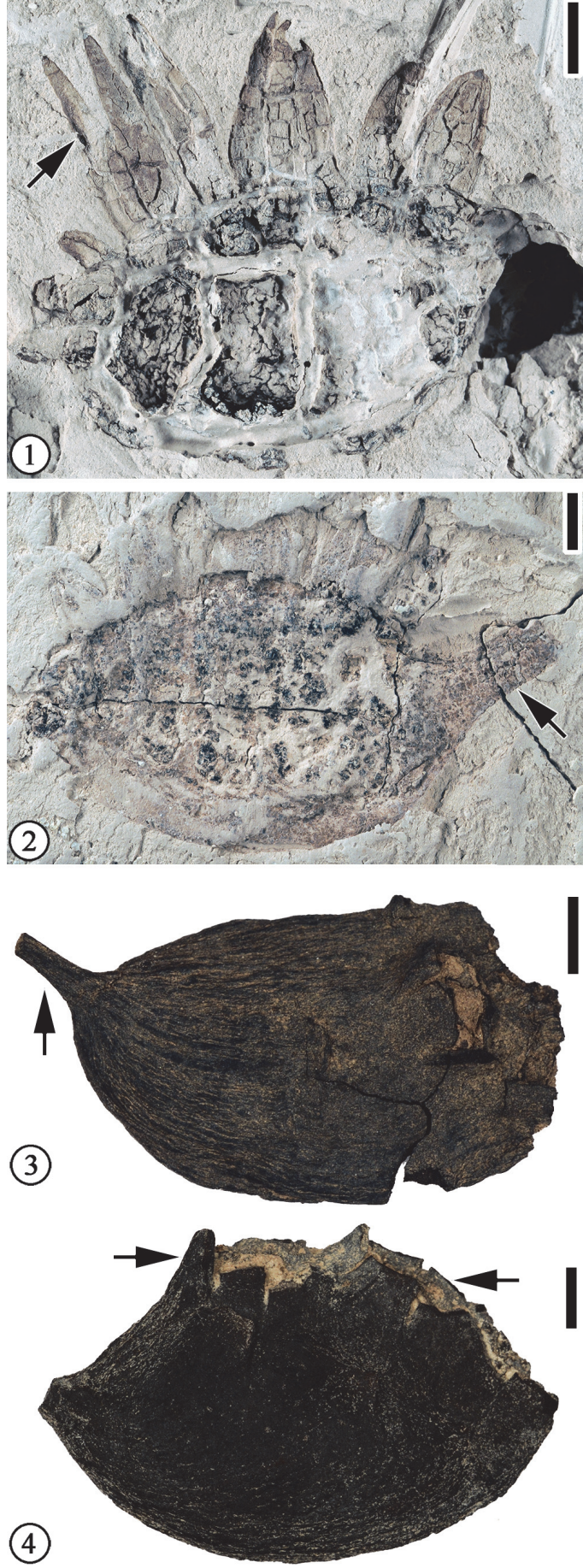

FIGURE 61. Claiborne Fruit/Seed Type 2: 1) UF15820002240, laterally compressed fruit/fruiting head with apically split appendages (indicated by arrow); 2) UF15820-059485, laterally compressed spatulate fruit/ fruiting head with a stout peduncle/pedicel (indicated by arrow). Cornerocarpon copiosum Grote (compressed, charcoalized fossil specimens for comparison): 3) UF15815-008198, laterally compressed fruit showing a peduncle (indicated by arrow); 4) 15815-53095, laterally compressed fruit showing broken bracts (indicated by arrows). All scale bars equal $3 \mathrm{~mm}$.

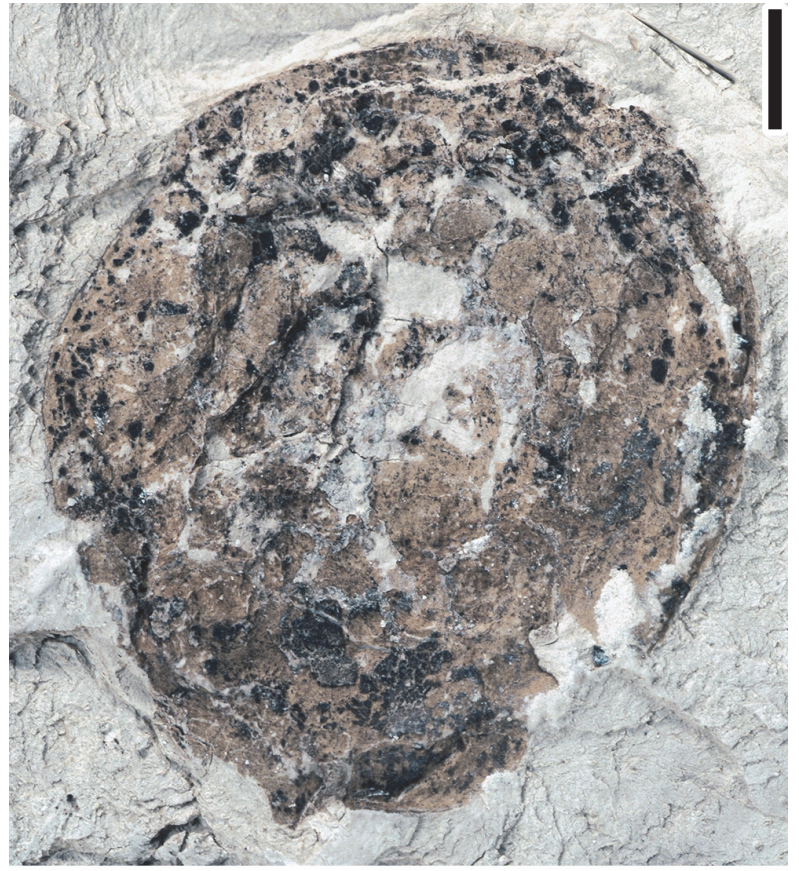

FIGURE 62. Claiborne Fruit/Seed Type 6: UF15820043597, compressed fruit/seed with a reticulate surface pattern. Scale bar equals $2 \mathrm{~mm}$.

$\mathrm{mm}$ long and $0.2 \mathrm{~mm}$ wide, decurrent along one side and extending to the base of the disseminule; two lateral attachments present on the same side of the disseminule.

Number of specimens examined. 2. UF15820061123.

Remarks. This disseminule probably represents a monocot (grass) fruit. It differs from Carpolithus boldensis from the Bolden locality, Mississippi (Blanchard et al., 2016, p. 42, figure 47) in that $C$. boldensis has a thin awn, a lemma and a seed body.

\section{Claiborne Fruit/Seed Type 12 Figure 64}

Description. Spherical fruit ca. $3.5 \mathrm{~mm}$ in diameter, with an apical projection ca. $0.5 \mathrm{~mm}$ long. Pedicel stout, ca. $2 \mathrm{~mm}$ long and $0.3 \mathrm{~mm}$ wide.

Number of specimens examined. 1. UF15820061144.

Remarks. Compared with "Copaifera" yeguana Berry (Wang et al., 2013, p. 53, figure 46), the Puryear fruit is smaller in size, and its mesocarp is probably very thin. As in "Copaifera" yeguana Berry, this fruit probably had a stony seed, indicated by the depression of the center of the compressed specimen. The apical projection probably represents a persistent style. 


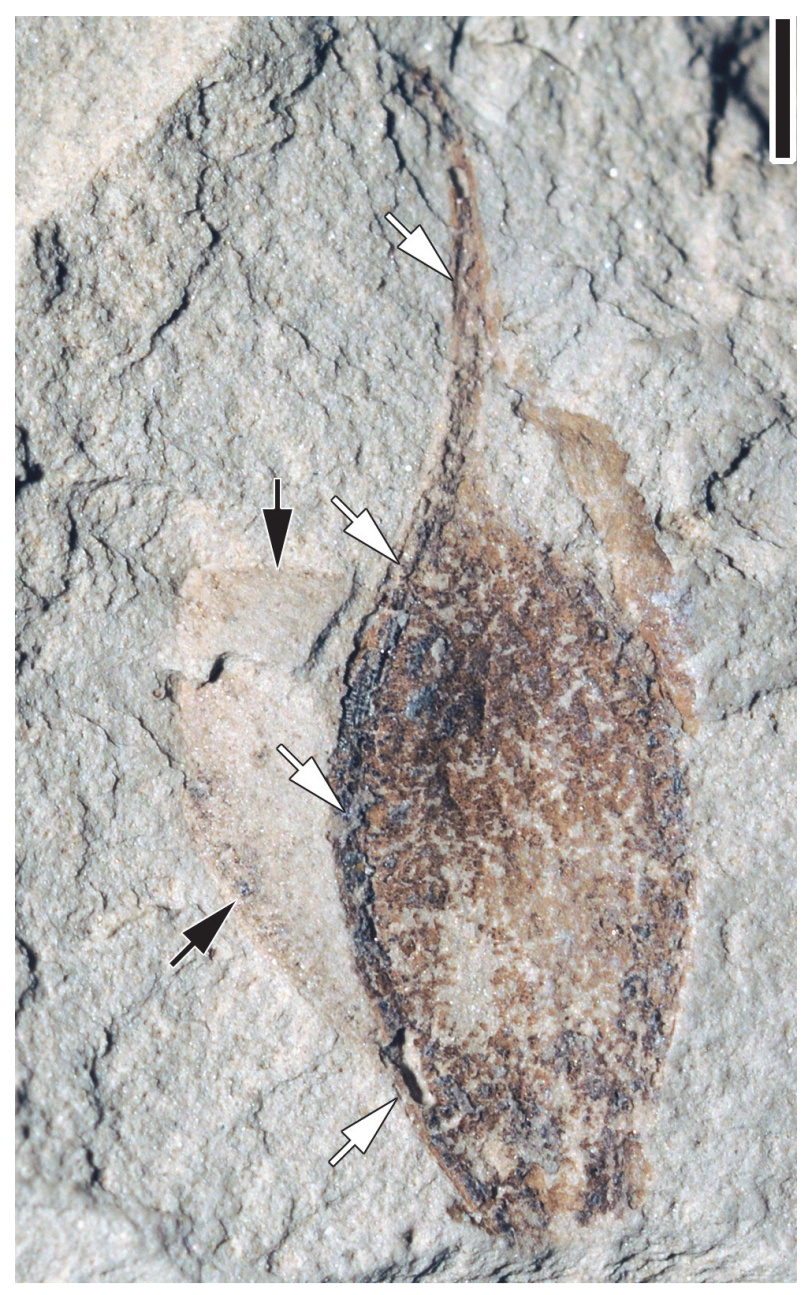

FIGURE 63. Claiborne Fruit/Seed Type 11: UF15820061123, specimen showing an elliptic disseminule with an apical extension that is decurrent on one side and extends to the base (indicated by four white arrows). Note two overlapping lateral attachments (indicated by black arrows). Scale bar equals $1 \mathrm{~mm}$.

\section{Claiborne Fruit/Seed Type 13 Figure 65}

Description. Capsular fruit, loculicidally dehiscent, with at least three curved valves; valve ca. $2.3 \mathrm{~cm}$ long and $1.1 \mathrm{~cm}$ wide, notched at the apex; one elliptic seed impression, ca. $1.8 \mathrm{~cm}$ long and $1 \mathrm{~cm}$ wide present at the center of each valve; a marginal zone ca. 2-3 $\mathrm{mm}$ wide present on both sides of each valve, except at the notched apex.

Number of specimens examined. 1. UF15820059205.

Remarks. This specimen probably represents a capsule that is dehiscent and releases seeds when the fruit is mature. The number of valves and locules and the number of seeds are unknown. The

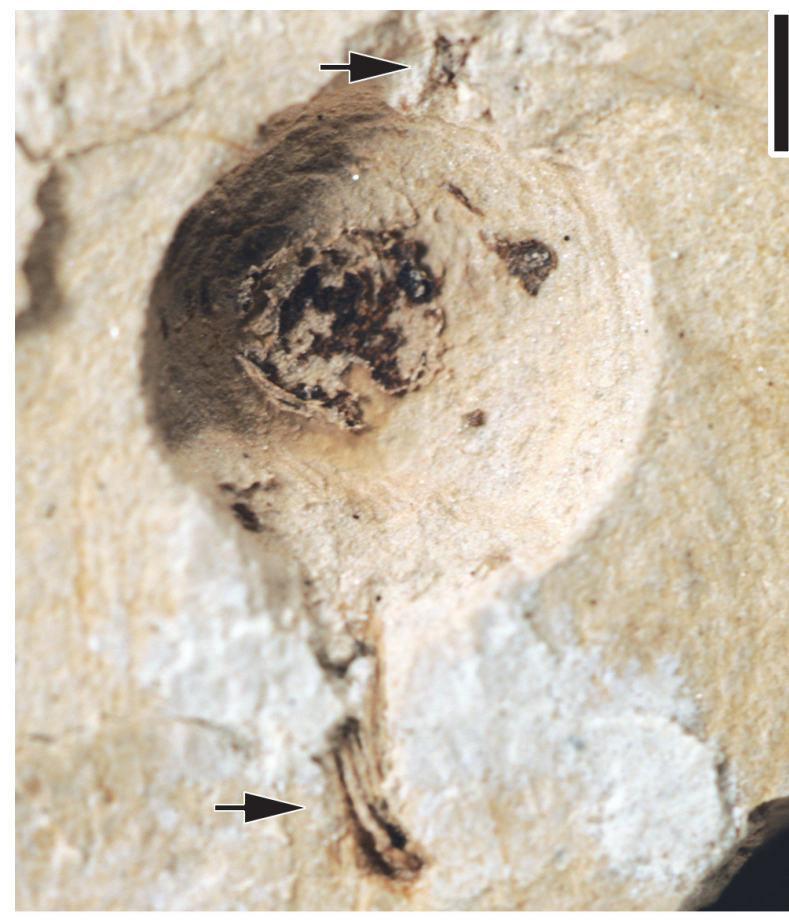

FIGURE 64. Claiborne Fruit/Seed Type 12: UF15820061144, showing an orbicular fruit with an apical projection at the distal end (indicated by arrow) and a stout pedicel at the base (indicated by arrow). Scale bar equals $1 \mathrm{~mm}$.

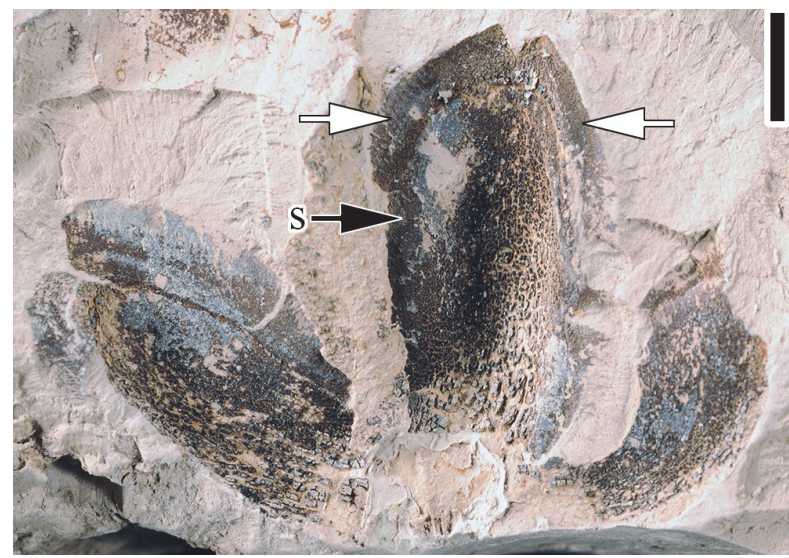

FIGURE 65. Claiborne Fruit/Seed Type 13: UF15820059205, showing incomplete, dehiscent capsule with three valves observed. Note seed impression (s), two marginal zones on each valve (indicated by white arrows), and the notched valve apices. Scale bar equals $5 \mathrm{~mm}$.

elliptic impression on each valve probably represents the shape of the seed.

The valves of this fruit differ from those of Andrewsiocarpon puryearensis (Figure 30, this paper), a loculicidally dehiscent capsule with five 


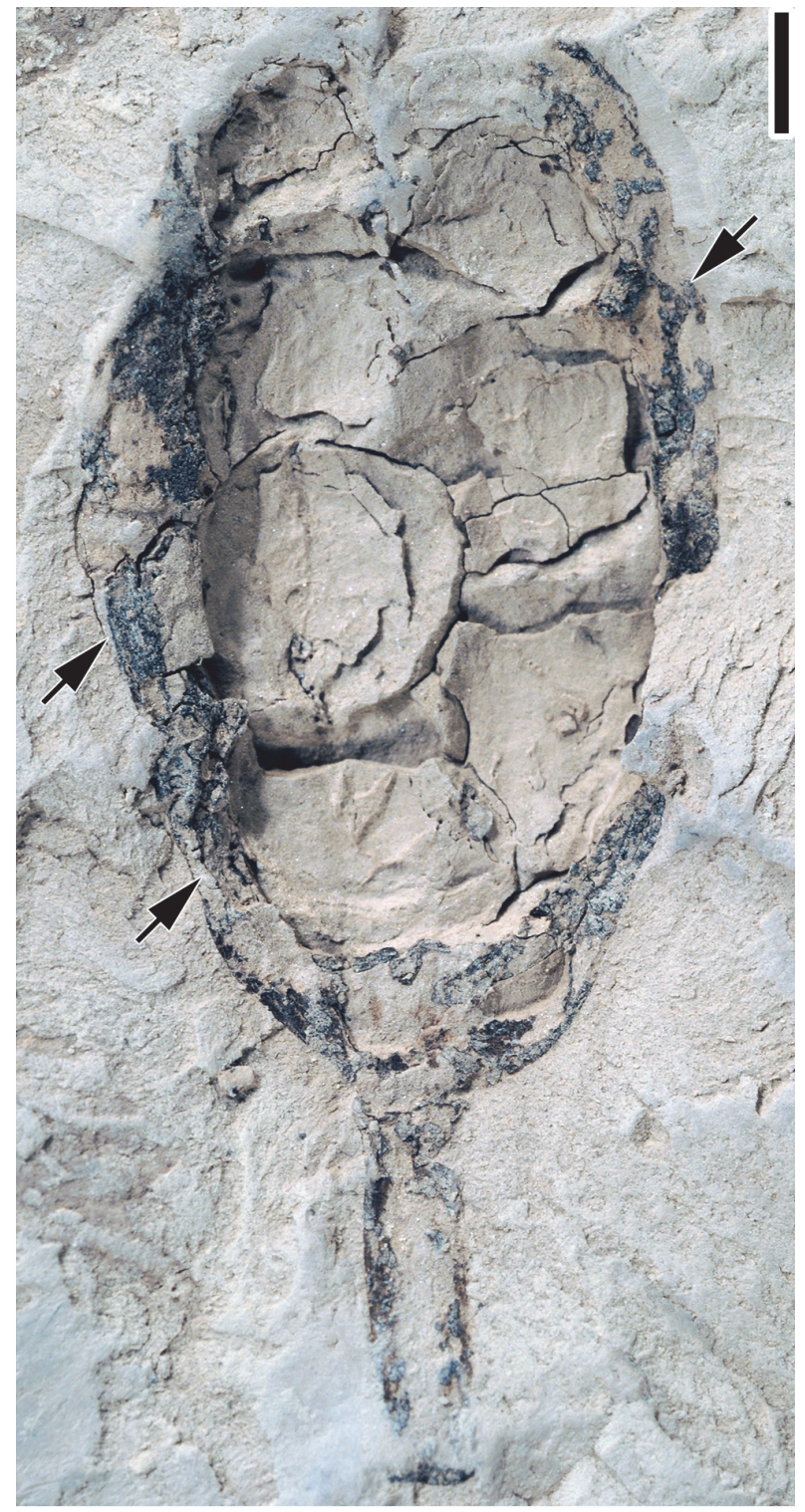

FIGURE 66. Claiborne Fruit/Seed Type 14: UF15820059406, fruit with seven seeds enclosed in fruit wall (indicated by arrows). Scale bar equals $3 \mathrm{~mm}$.

valves and winged seeds, in that they lack a medial ridge and an apical beak, and that they are shorter and wider $(2.3 \mathrm{~cm}$ long and $1.1 \mathrm{~cm}$ wide vs $2.5-3$ $\mathrm{cm}$ long and $9 \mathrm{~mm}$ wide).

\section{Claiborne Fruit/Seed Type 14 Figure 66}

Description. Obovate fruit ca. $2.5 \mathrm{~cm}$ long and 1.7 $\mathrm{cm}$ at the widest point. Fruit wall ca. $2 \mathrm{~mm}$ thick enclosing ca. seven-eight seeds each ca. $5-7 \mathrm{~mm}$ in diameter. Pedicel ca. $10 \mathrm{~mm}$ long and $2 \mathrm{~mm}$ wide.
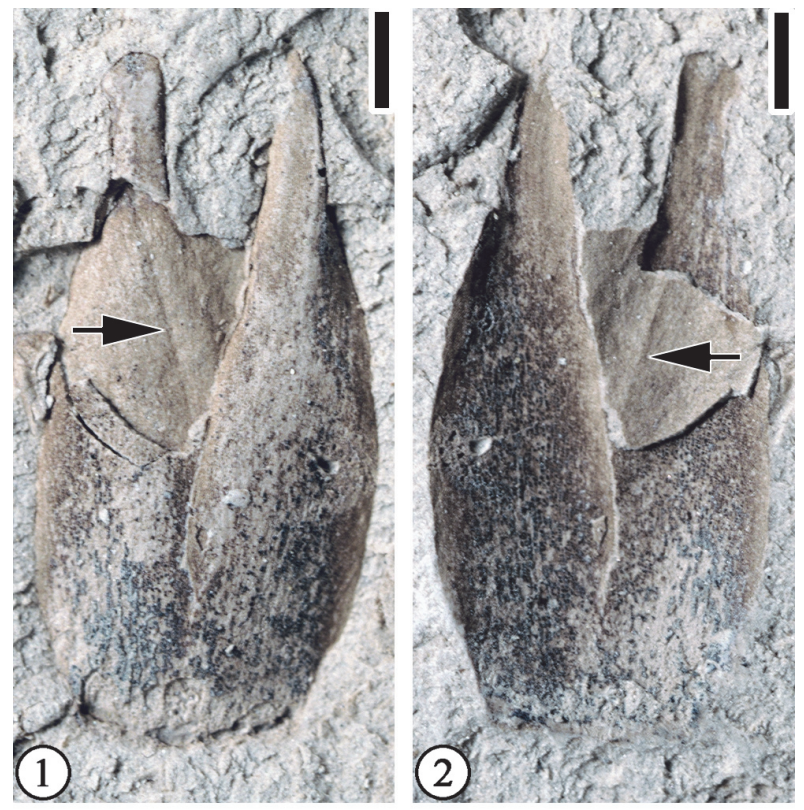

FIGURE 67. Claiborne Fruit/Seed Type 15: 1, 2) UF15820-059466, 059466', part and counterpart of a specimen show two overlapping bracts enclosing another structure with a prominent middle ridge/grove (indicated by arrows). All scale bars equal $1 \mathrm{~mm}$.

Number of specimens examined. 1. UF15820059406.

Remarks. This fruit is similar to Claiborne Infructescence Type 1 (Wang et al., 2013, p. 41, figure 31; Figure 48). However, this specimen represents a fruit, rather than an infructescence, because the seeds are enclosed within a fruit wall (probably exocarp and mesocarp) that is about $2 \mathrm{~mm}$ thick. The individual seeds of this fruit are larger than the individual fruits of Claiborne Infructescence Type 1.

\section{Claiborne Fruit/Seed Type 15}

Figure 67

Description. A partially opened fruiting structure showing two overlapping bracts enclosing another structure with a prominent middle ridge/groove. The bracts separate, ca. $7 \mathrm{~mm}$ long and ca. $2 \mathrm{~mm}$ wide tapering to an acute apex, fine striations present.

Number of specimens examined. 1. UF15820059466, 059466'.

Remarks. The bract of this structure is similar in size and shape to one of the dispersed (or detached) bracts reported from the Puryear locality by Berry (1930, p. 143, pl. 48, figure 24). However, the striations are not as pronounced.

This specimen possibly represents a grass spikelet. It differs from the monocot disseminule, 


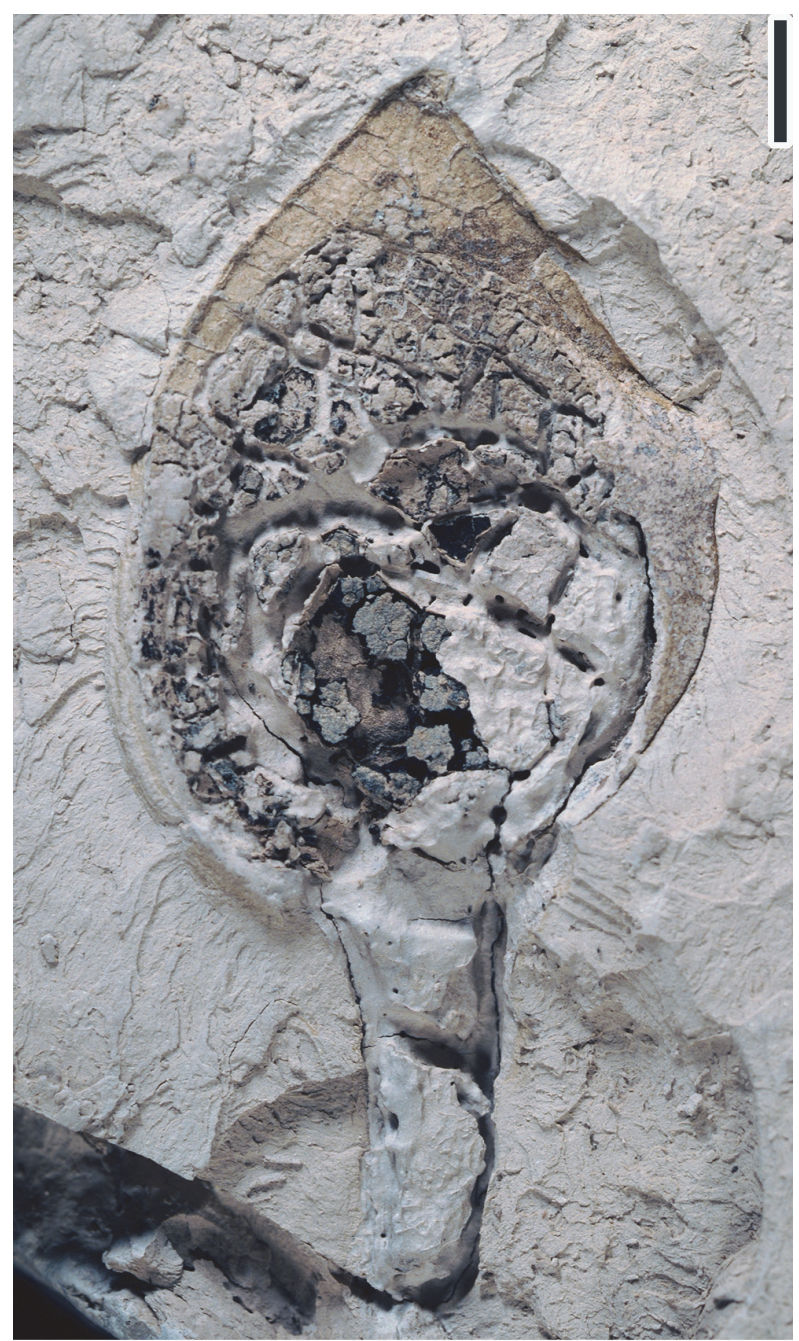

FIGURE 68. Claiborne Fruit/Seed Type 16: UF15820059479, laterally compressed ovoid fruiting structure. Scale bar equals $3 \mathrm{~mm}$.

Carpolithus boldensis, from the Bolden locality, Mississippi (Blanchard et al., 2016, p. 42, figure 37) in the absence of an awn at the distal end of the bracts.

\section{Claiborne Fruit/Seed Type 16}

Figure 68

Description. Laterally compressed ovoid fruiting structure ca. $2 \mathrm{~cm}$ long and ca. $1.5 \mathrm{~cm}$ at the widest point. Pedicel ca. $1 \mathrm{~cm}$ long and $0.3 \mathrm{~cm}$ wide. Mesocarp ca 1.5-2 $\mathrm{mm}$ thick. No seeds distinguishable.

Number of specimens examined. 1. UF15820059479.

Remarks. In gross morphology, this specimen is similar to Bignonicapsula formosa Berry (Berry, 1930, p. 132, pl. 43, figure 3). However, this fruit/ seed type from Puryear does not have flat, winged seeds inside the capsule. It is possible that this specimen represents a single-seeded legume pod such as Copaifera.

\section{Claiborne Fruit/Seed Type 17 Figure 69}

Description. Laterally compressed obovate fruit/ seed ca. $2 \mathrm{~cm}$ long (excluding pedicel) and $1.5 \mathrm{~cm}$ wide at the middle. Margin entire. Pedicel ca. 3.8 $\mathrm{mm}$ long and $1 \mathrm{~mm}$ wide.

Number of specimens examined. 2. UF15820059455, 059486.

Remarks. One specimen only shows the attachment scar at the base. A smaller specimen (UF15820-059486) is similar in shape with pedicel attached. The rough surface is possibly due to a difference in preservation.

\section{Claiborne Fruit/Seed Type 18 \\ Figure 70}

Description. Laterally compressed ovate fruit/ seed $6 \mathrm{~mm}$ long and $3 \mathrm{~mm}$ wide. Pedicel incomplete, ca. $3.5 \mathrm{~mm}$ long and $1.5 \mathrm{~mm}$ wide. Apical spine $2 \mathrm{~mm}$ long.

Number of specimens examined. 1. CONN-Q0902.

Remarks. This fruit/seed type has a relative strong pedicel and an apical spine.

\section{Claiborne Fruit/Seed Type 19}

Figure 71

Description. An incomplete winged fruit including a circular fruit body (ca. $6 \mathrm{~mm}$ in diameter) covered with spines (ca. $3 \mathrm{~mm}$ long and $0.1-0.3 \mathrm{~mm}$ wide) and a wing (at least $12 \mathrm{~mm}$ wide) with radiating veins.

Number of specimens examined. 1. CONN-Q1P19.

Remarks. The combination of a circular fruit body covered with spines and a wing with radiating veins can be used to distinguish this fruit type from Paleooreomunnea stoneana Dilcher, Potter and Crepet (Berry 1930, p. 60, pl. 46, figures 11, 12; Dilcher et al., 1976, p. 539, figures 26-32; Manchester, 1987 , p. 59 , figure $28 \mathrm{E}-\mathrm{L}$; Wang et al., 2013, p. 23-24, figure 19) and Claiborne Fabaceae Fruit Type 1 . Because only one incomplete specimen is examined, we tentatively assign this specimen within Angiosperm Incertae Sedis.

Plant Insertae Sedis - Undetermined

Claiborne Bract Type 1

Figure 72 

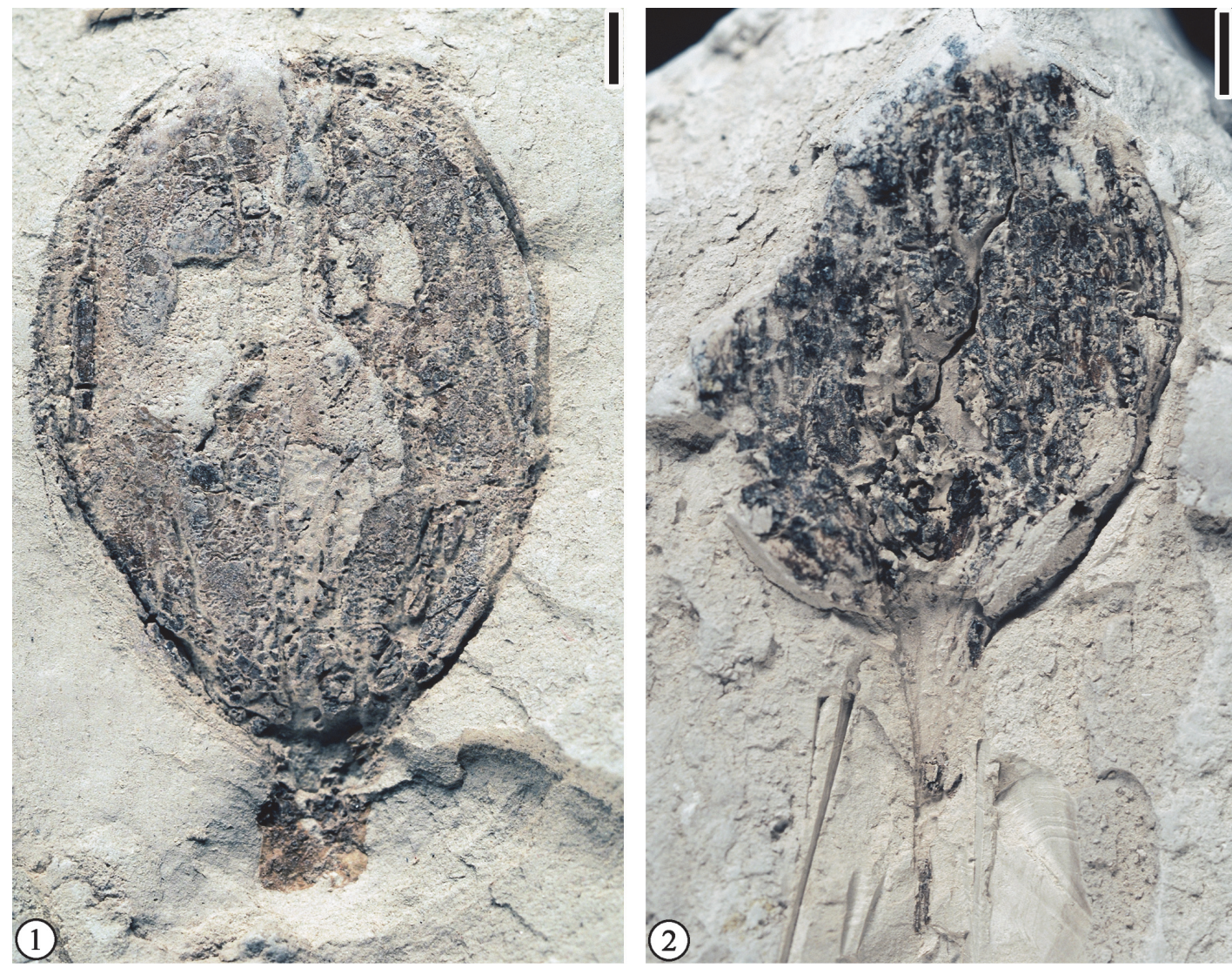

FIGURE 69. Claiborne Fruit/Seed Type 17: 1) UF15820-059455, laterally compressed obovate reproductive structure; 2) UF15820-059486, a smaller fruit/seed with an attached pedicel. All scale bars equal $2 \mathrm{~mm}$.

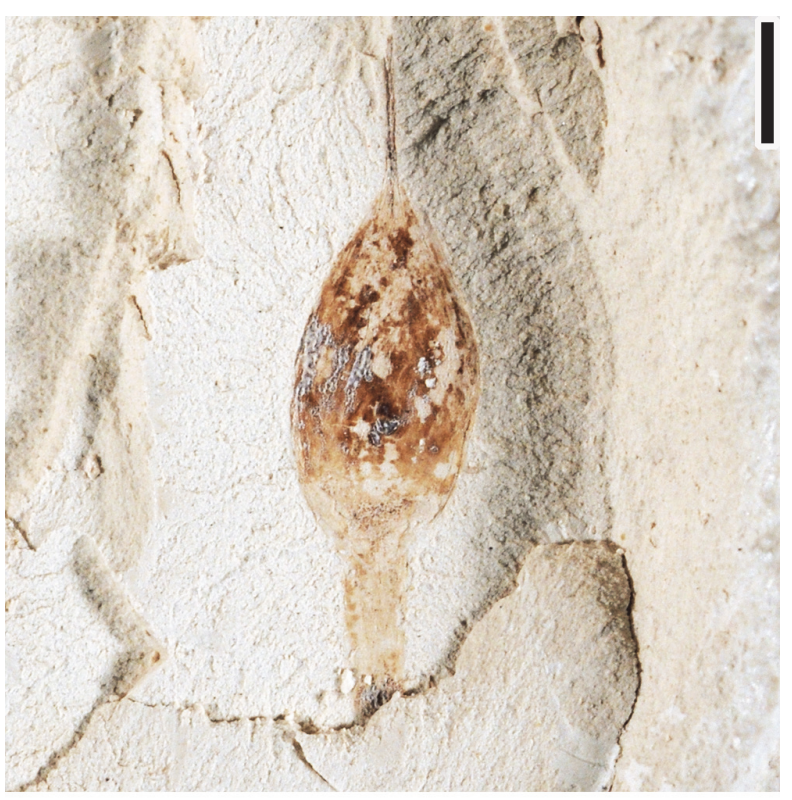

FIGURE 70. Claiborne Fruit/Seed Type 18: CONN-Q0902 , laterally compressed fruit/seed with attached pedicel and apical spine. Scale bar equals $2 \mathrm{~mm}$.
Description. Bract orbicular to lanceolate in outline, varying from $20 \mathrm{~mm}$ long and $14 \mathrm{~mm}$ wide to $10 \mathrm{~mm}$ long and $3 \mathrm{~mm}$ wide; margin entire; base concave, clasping, overall shape slightly cordate to auricular; apex tapering abruptly or gradually to an acute apex; venation parallel and extending directly to the apex in the middle portion of the lamina; lateral veins branching or parallel in the basal portion and convergent when close to the margin; lamina heavily pubescent, covered with trichomes about $0.2-0.3 \mathrm{~mm}$ long.

Number of specimens examined. 14. UF15820059462, 059452, 059454, 059456.

Remarks. The two specimens described by (Berry, 1930) pl. 48, figs 24, 25) are also from the Puryear locality and they probably belong to the same type. As Berry suggested, these specimens probably represent bracts or bud scales of plants with unknown affinities. 

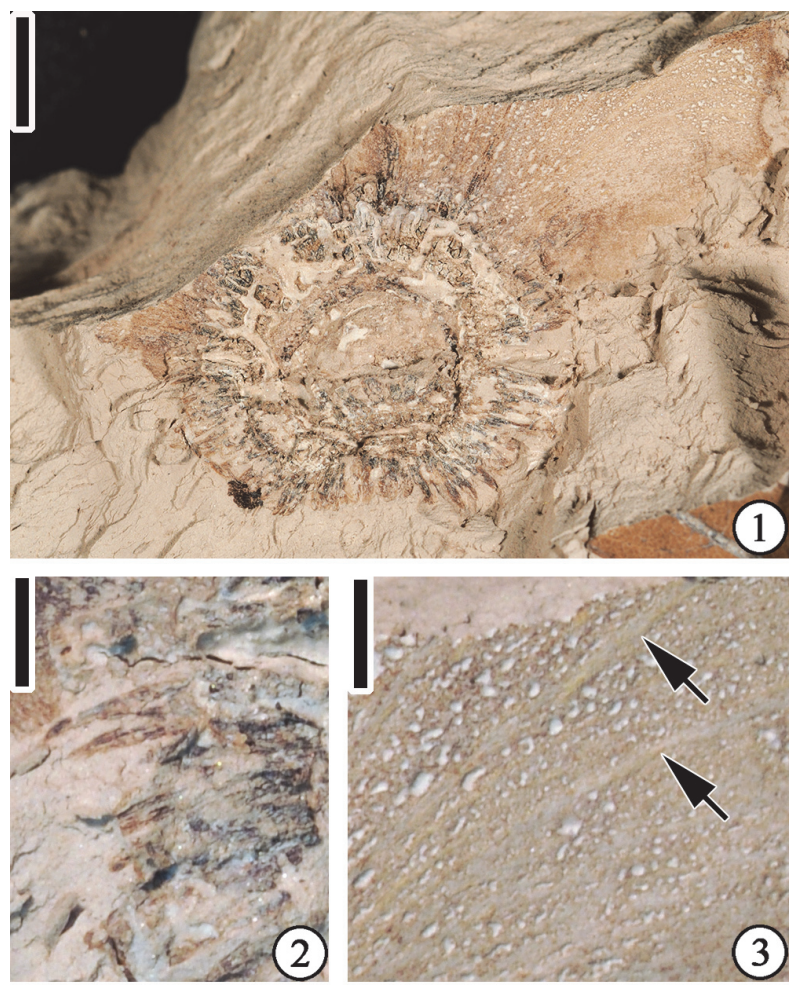

FIGURE 71. Claiborne Fruit/Seed Type 19: 1) CONNQ1-P19, specimen showing circular fruit body with spines and an incomplete wing. Scale bar equals $4 \mathrm{~mm}$; 2) Enlargement of the lower left of Figure 71.1 to show spines. Scale bar equals $1 \mathrm{~mm}$; 3) Enlargement of Figure 71.1 to show veins (indicated by arrows) Scale bar equals $1 \mathrm{~mm}$.

\section{DISCUSSION}

\section{Floristic Composition of the Puryear Locality}

Seventy-two taxa/morphotypes are recognized from the Puryear locality, Tennessee. Among them, 32 are identified to 12 extant families. These taxa/morphotypes include Claiborne Altingiaceae Infructescence Type 1 (Altingiaceae), Paleopanax puryearensis sp. nov. (Araliaceae), Claiborne Arecaceae Fruit Type 1 and Claiborne Arecaceae Infructescence Type 1 (Arecaceae), Ceratophyllum muricatum Cham. subspecies incertum (Berry) Herendeen, Les and Dilcher (Ceratophyllaceae), Pteroceltis knowltonii (Berry) Manchester, Chen, Lu and Uemura (Cannabaceae), Crepetocarpon perkinsii (Berry) Dilcher and Manchester (Euphorbiaceae), Caesalpinia claibornensis Herendeen and Dilcher, cf. Caesalpinia sp., cf. Cladrastis sp., Protomimosoidea buchananensis Crepet and Taylor, cf. Leguminosites ingafructoides Berry, Claiborne Fabaceae Floral Type 1 to 3, Claiborne Fabaceae Fruit/Seed Type 1, "Fruits similar to the
Sophoreae", and "Short, broad winged fruit" (Fabaceae), Castanopsoidea columbiana Crepet and Nixon, Castaneoidea puryearensis Crepet and Daghlian, Trigonobalanoidea americana Crepet and Nixon, and Claiborne Fagaceae Fruit Type 2, 5 and 6 (Fagaceae), Eoengelhardia puryearensis Crepet, Daghlian and Zavada, Palaeocarya puryearensis (Berry) Manchester, and Paraengelhardtia eocenica Berry (Juglandaceae), Fraxinus wilcoxiana (Berry) Call and Dilcher (Oleaceae), Andrewsiocarpon puryearensis sp. nov. (Theaceae), and Eoceltis dilcheri (Ulmaceae). The rest (40 taxa/morphotypes) do not have enough diagnostic characters to access their modern affinities.

Of the 12 recognized extant families, the Fabaceae (11 taxa/morphotypes) and Fagaceae (7 taxa/morphotypes) are the two dominant groups in number of taxa/morphotypes and in number of specimens. This dominance by the members of the Fabaceae and Fagaceae is consistent with the leaf fossil record at the Puryear and other Claiborne localities (personal observation).

Potter and Dilcher (1980), Moore et al. (2000), and Moore (2001) suggest that the Puryear plant macrofossils are most closely allied with taxa living today in modern climates that are seasonally dry to moist and having a temperature regime varying from warm-temperate to cool-subtropical.

\section{Comparison of Floristic Components of the Puryear Locality and Other Claiborne Localities}

The Puryear locality is the most diverse among all three Claiborne localities, with a total of 72 recognized taxa/morphotypes of which 50 are unique to the Puryear locality. Fifteen (11) taxa/ morphotypes are shared with Warman (Wang et al., 2013). Eight (8) taxa/morphotypes are shared with Bovay and/or Bolden (Blanchard et al., 2016). Of the 155 total taxa/morphotypes recognized from the Puryear (50 unique), Warman (42 unique), and Bovay/Bolden (34 unique) localities, only three (Palmocarpon wilcoxiana, Protomimosoidea buchanensis, and Claiborne Floral Type 5) are common to all three localities.

\section{Evolutionary Significance}

Sedimentary environments at these clay pits from which the specimens examined here were collected have been interpreted as typical oxbow lake depositional systems (Dilcher, 1971; Potter, 1976; Potter and Dilcher, 1980). Each clay pit (lens) represents a similar depositional history with some variation in the extent of associated lignite 

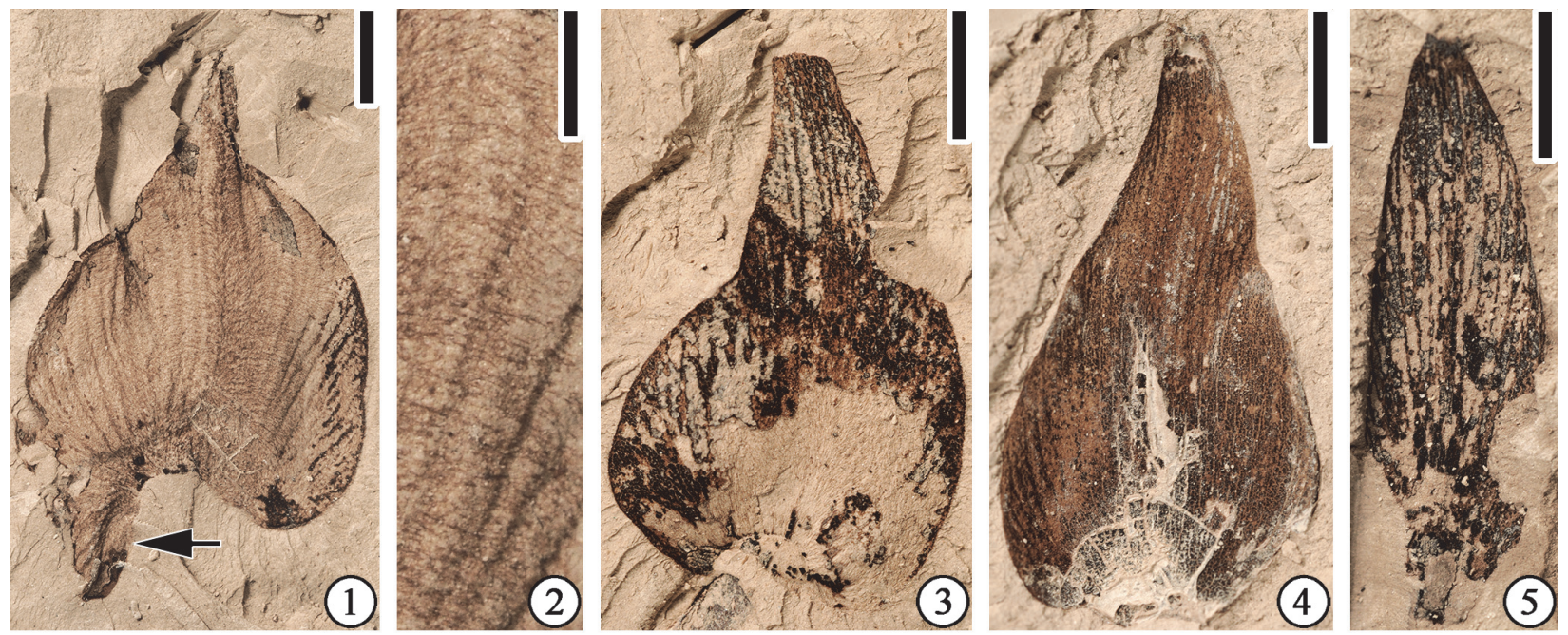

FIGURE 72. Claiborne Bract Type 1: 1) UF15820-059452, an orbicular bract with auricular base on one side and slightly cordate base on the other side. Note parallel veins in the middle and convergent veins on two lateral sides of the bracts; 2) Enlargement of Figure 72.1 to show trichomes; 3) UF15820-059456, bract with a cordate base; 4) UF15820-059454, an ovate bract. Note parallel veins in the middle and convergent veins on lateral sides of the bract; 4) UF15820-059462, a lanceolate bract. All scale bars equal $3 \mathrm{~mm}$, except in Figure 72.2, which equals $1 \mathrm{~mm}$.

and relative abundance of plant fossils. Potter and Dilcher (1976) suggested that some floristic variations may be ecological effects. Other differences, including floristic components, relative abundance, form, and anatomy of the plants among the various localities, are probably resulted from evolutionary changes, because each clay lens (locality) represents a very short-term geological event lasting approximately 500 to 1500 years (Potter and Dilcher, 1980). However, the extent of the entire depositional events represented by these clay pits (Figure 2; Table 2) is of sufficient time length to provide an excellent opportunity for detailed evolutionary studies between individual localities.

\section{CONCLUSIONS}

The Puryear locality is the most species-rich among the three localities (Bovay/Bolden, Puryear, and Warman) from the middle Eocene Claiborne Group examined so far with a total of 72 recognized taxa/morphotypes.

Of the 50 taxa/morphotypes that are unique to the Puryear locality, two new species, i.e., Andrewsiocarpon puryearensis sp. nov. and Paleopanax puryearensis $\mathrm{sp}$. nov. are established. The results confirm our previous observation that there is a remarkable lack of species overlap among the localities examined to date. Of the 155 taxa/morphotypes recognized from the Bovay/Bolden, Warman clay pit, and Puryear localities, only three taxa/morphotypes, i.e., Palmocarpon wilcoxiana,
Protomimosoidea buchanensis, and Claiborne Floral Type 5, are shared by all three localities. The apparent small species overlap among the localities is probably resulted from the evolutionary changes, although some floristic variations may be ecological.

\section{ACKNOWLEDGMENTS}

We thank D. Dilcher and his numerous friends, colleagues, and students who have helped collect specimens from the Puryear locality, D. Les and S. Taylor for their help in accessing specimens in CONN Herbarium, University of Connecticut, C. Snyder for photographing some specimens, and two anonymous reviewers for their helpful comments and suggestions on the manuscript. Financial support for this work was provided by the University of Florida Foundation Becker-Dilcher Paleobotany Endowment (HW) and the National Natural Science Foundation of China (41702008; YN).

\section{DEDICATION}

This paper is dedicated to Dr. David L. Dilcher, the first paleobotanist to study the megafossil floras from the middle Eocene clay deposits in Tennessee and Kentucky since Charles L. Lesquereux (1869), Edward W. Berry (1916b, 1924, 1930, 1941), and Roland W. Brown (1944, 1946, 1960). With the help of directions and advice in a letter 


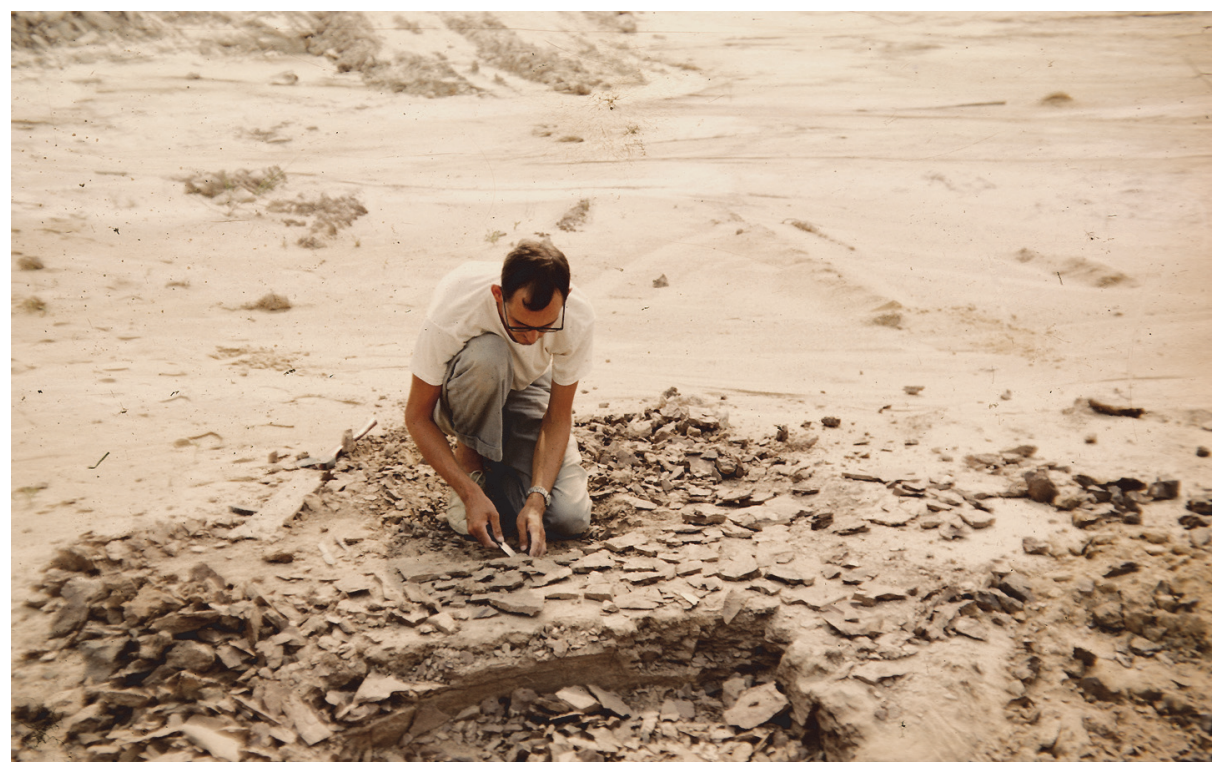

FIGURE 73. David Dilcher collecting fossil plants at the Puryear clay pit, Tennessee, in the summer of 1959.

from Eugene S. Richardson, Jr., Curator of Fossil Invertebrates at the Chicago Natural History Museum (now Field Museum of Natural History), David Dilcher, with his friend, Robert C. Hodson, while driving from Minnesota to Maine, Florida, and back to Minnesota, stopped at the Puryear clay pit near Paris, Tennessee in the summer of 1959 (Figure 73). He was fascinated by the abundance and quality of the well-preserved fossil plant material, including leaves, fruits, and seeds. His specimens from Puryear became the subjects of his master's thesis on fossil cuticle and pollen at the University of Minnesota in 1960, and later served as the basis for his Ph.D. dissertation in 1964 at Yale University. This and many subsequent trips resulted in a collection of about 20 cabinets of specimens, which are the basis for numerous paleobotanical, paleoenvironmental, and palynological studies on the Eocene floras of Kentucky, Mississippi and Tennessee by David Dilcher, his colleagues, and his students. We are happy to dedicate this paper to him in recognition of his long-time contribution to the collection and study of fossil plants from Puryear and other localities in the southeast United States.

\section{REFERENCES}

APG IV. 2016. An update of the Angiosperm Phylogeny Group classification for the orders and families of flowering plants: APG IV. Botanical Journal of the Linnean Society, 181:1-20. https://doi.org/10.1111/boj.12385

Ball, O.M. 1931. A contribution to the paleobotany of the Eocene of Texas. Bulletin of the Agricultural and Mechanical College of Texas, 2:1-173.

Berry, E.W. 1914a. Fruits of a date palm in the Tertiary deposits of eastern Texas. American Journal of Science, 4th series, 37:403-406. https://doi.org/10.2475/ajs.s4-37.221.403

Berry, E.W. 1914b. The Cretaceous and Eocene floras of South Carolina and Georgia. United States Geological Survey Professional Paper, 84:1-200. https://doi.org/10.3133/pp84

Berry, E.W. 1916a. Remarkable fossil fungi. Mycologia, 8:73-79. https://doi.org/10.1080/ 00275514.1916.12018866

Berry, E.W. 1916b. The lower Eocene floras of southeastern North America. United States Geological Survey Professional Paper, 91:1-481. https://doi.org/10.3133/pp91 
Berry, E.W. 1919. Upper Cretaceous floras of the eastern Gulf region in Tennessee, Mississippi, Alabama, and Georgia. United States Geological Survey Professional Paper, 112:1-177. https://doi.org/10.3133/pp112

Berry, E.W. 1922. Additions to the flora of the Wilcox Group. United States Geological Survey Professional Paper, 131-A:1-21. https://doi.org/10.3133/pp131A

Berry, E.W. 1924. The middle and upper Eocene floras of southeastern North America. United States Geological Survey Professional Paper, 92:1-206. https://doi.org/10.3133/pp92

Berry, E.W. 1926. Terminalia in the lower Eocene of southeastern North America. Bulletin of the Torrey Botanical Club, 53:59-65. https://doi.org/10.2307/2480046

Berry, E.W. 1928. A new type of caddis case from the lower Eocene of Tennessee. U.S. Natural Museum Proceedings, 71:14. https://doi.org/10.5479/si.00963801.71-2686.1

Berry, E.W. 1930. Revision of the lower and upper Eocene Wilcox flora of the southeastern states. U.S. Geological Survey Professional Paper, 156:1-196. https://doi.org/10.3133/pp156

Berry, E.W. 1941. Additions to the Wilcox flora from Kentucky and Texas. United States Geological Survey Professional Paper, 193-E:83-99. https://doi.org/10.3133/pp193e

Blanchard, J., Wang, H., and Dilcher, D.L. 2016. Fruits, seeds and flowers from the Bovay and Bolden clay pits (early Eocene Tallahatta Formation, Claiborne Group), northern Mississippi, USA. Palaeontologia Electronica 19.3.51A:1-59. https://doi.org/10.26879/579

Bromhead, E.F. 1838. An attempt to ascertain characters of the botanical alliances. Edinburgh New Philosophical Journal, 25:123-134.

Bromhead, E.F. 1840. Remarks on the botanical system of Professor Perleb. The Annals and Magazine of Natural History, and Journal of Zoology, Botany, and Geology, 4:329-338.

Brown, R.W. 1944. Temperate species in the Eocene flora of the southeastern United States. Journal of the Washington Academy of Sciences, 34:349-351.

Brown, R.W. 1946. Alterations in some fossil and living floras. Journal of the Washington Academy of Sciences, 36:344-355.

Brown, R.W. 1960. Corkwood in the Eocene flora of the southeastern Unites States. Journal of Paleontology, 34:429-432.

Call, V.B. and Dilcher, D.L. 1992. Investigations of angiosperms from the Eocene of southeastern North America: samaras of Fraxinus wilcoxiana Berry. Review of Palaeobotany and Palynology, 74:249-266. https://doi.org/10.1016/0034-6667(92)90010-e

Call, V.B. and Dilcher, D.L. 1995. Fossil Ptelea samaras (Rutaceae) in North America. American Journal of Botany, 82:1069-1073. https://doi.org/10.1002/j.1537-2197.1995.tb11572.x

Cardoso, D., Pennington, R.T., De Queiroz, L.P., Boatwright, J.S., Van Wyk, B.-E., Wojciechowski, M.F., and Lavin, M. 2013. Reconstructing the deep-branching relationships of the papilionoid legumes. South African Journal of Botany, 89:58-75. https://doi.org/ 10.1016/j.sajb.2013.05.001

Crepet, W.L. and Daghlian, C.P. 1980. Castaneoid inflorescences from the middle Eocene of Tennessee and the diagnostic value of pollen (at the subfamily level) in the Fagaceae. American Journal of Botany, 67:739-757. https://doi.org/10.1002/j.15372197.1980.tb07704.x

Crepet, W.L., Daghlian, C.P., and Zavada, M. 1980. Investigations of angiosperms from the Eocene of North America: a new juglandaceous catkin. Review of Paleobotany and Palynology, 30:361-370. https://doi.org/10.1016/0034-6667(80)90019-6

Crepet, W.L., Dilcher, D.L., and Potter, F.W. 1975. Investigations of angiosperms from the Eocene of North America: a catkin with juglandaceous affinities. American Journal of Botany, 62:813-823. https://doi.org/10.1002/j.1537-2197.1975.tb14120.x

Crepet, W.L. and Herendeen, P.S. 1992. Fossil papilionoid flowers from the Palaeocene-Eocene of southeastern North America, p. 43-55. In Herendeen, P.S. and Dilcher, D.L. (eds.), Advances in Legume Systematics, Part 4. The Fossil Record. The Royal Botanical Gardens, Kew.

Crepet, W.L. and Nixon, K.C. 1989. Earliest megafossil evidence of Fagaceae: phylogenetic and biogeographic implications. American Journal of Botany, 76:842-855. https://doi.org/10.1002/ j.1537-2197.1989.tb15062.x

Crepet, W.L. and Taylor, D.W. 1986. Primitive mimosoid flowers from the Paleocene-Eocene and their systematic and evolutionary implications. American Journal of Botany, 73:548-563. https://doi.org/10.1002/j.1537-2197.1986.tb12075.x

de Jussieu, A.L. 1789. Genera Plantarum, Secundum Ordines Naturales Disposita juxta Methodum in Horto Regio Parisiensi Exaratam. Herissant \& Barrois, Paris. 
Dilcher, D.L. 1971. A revision of the Eocene flora of southeastern North America. The Palaeobotanist, 20:7-18.

Dilcher, D.L. 1974. Approaches to the identification of angiosperm leaf remains. The Botanical Review, 40(1):1-158. https://doi.org/10.1007/bf02860067

Dilcher, D.L. and Dolph, G.E. 1970. Fossil leaves of Dendropanax from Eocene sediments of southeastern North America. American Journal of Botany, 57:153-160. https://doi.org/ 10.1002/j.1537-2197.1970.tb09801.x

Dilcher, D.L. and Lott, T.A. 2005. A middle Eocene fossil plant assemblage (Powers clay pit) from western Tennessee. Bulletin of the Florida Museum of Natural History, 45:1-43.

Dilcher, D.L. and Manchester, S.R. 1988. Investigations of angiosperms from the Eocene of North America: a fruit belonging to the Euphorbiaceae. Tertiary Research, 9:45-58.

Dilcher, D.L. and McQuade, J.F. 1967. A morphological study of Nyssa endocarps from Eocene deposits in western Tennessee. Bulletin of the Torrey Botanical Club, 94:35-40. https:// doi.org/10.2307/2483600

Dilcher, D.L., Potter, F.W., and Crepet, W.L. 1976. Investigations of angiosperms from Eocene of North America: juglandaceous winged fruits. American Journal of Botany, 63:532-544. https:/ /doi.org/10.1002/j.1537-2197.1976.tb11842.x

Dockery, D.T. 1996. Toward a revision of the generalized stratigraphic column of Mississippi. Mississippi Geology, 17:1-9.

Dumortier, B.C.J. 1829. Analyse des Familles des Plantes, avec L'indication des Principaux Genres qui s'y Rattachent. Casterman, Tournay.

Elsik, W.C. 1974. Characteristic Eocene palynomorphs in the Gulf Coast, U.S.A Palaeontographica, Abst. B, 149:90-111.

Elsik, W.C. and Dilcher, D.L. 1974. Palynology and age of clays exposed in Lawrence clay pit, Henry County, Tennessee. Palaeontographica, Abst. B, 146:65-87.

Engler, H.G.A. 1892. Syllabus der Vorlesungen über Specielle und Medicinisch-Pharceutische Botanik. Gebrüder Borntraeger Verlag, Berlin.

Estrada-Ruiz, E., Calvillo-Canadell, L., and Cevallos-Ferriz, S.R.S. 2009. Upper Cretaceous aquatic plants from northern Mexico. Aquatic Botany, 90:282-288. https://doi.org/10.1016/ j.aquabot.2008.11.004

Fu, L.G., Xin, Y.Q., and Whittemore, A. 2003. Ulmaceae. Flora of China, 5:1-19.

Gray, J. 1960. Temperate pollen genera in the Eocene (Claiborne) flora, Alabama. Science, 132:808-810. https://doi.org/10.1126/science.132.3430.808

Gray, S.F. 1821. A Natural Arrangement of British Plants. Baldwin, Cradock and Joy, London.

Grote, P.J. 1989. Selected Fruits and Seeds from the Middle Eocene Claiborne Formation of Southeastern North America. University of Indiana, Bloomington, Indiana.

Grote, P.J. and Dilcher, D.L. 1989. Investigations of angiosperms from the Eocene of North America: A new genus of Theaceae based on fruit and seed remains. Botanical Gazette, 150:190-206. https://doi.org/10.1086/337764

Herendeen, P.S. 1992. The fossil history of the Leguminosae from the Eocene of southeastern North America, p. 85-160. In Herendeen, P.S. and Dilcher, D.L. (eds.), Advances in Legume Systematics: Part 4. The Fossil Record. The Royal Botanic Gardens, UK, Kew.

Herendeen, P.S. and Dilcher, D.L. 1991. Caesalpinia subgenus Mezoneuron (Leguminosae, Caesalpinioideae) from the Tertiary of North America. American Journal of Botany, 78:1-12. https://doi.org/10.1002/j.1537-2197.1991.tb12566.x

Herendeen, P.S., Les, D.H., and Dilcher, D.L. 1990. Fossil Ceratophyllum (Ceratophyllaceae) from the Tertiary of North America. American Journal of Botany, 77:7-16. https://doi.org/ 10.1002/j.1537-2197.1990.tb13522.x

Hoffmannsegg, J.C. and Link, J.H.F. 1809. Flore Portugaise, 1. Amelang, Berlin.

Ickert-Bond, S.M., Pigg, K.B., and Wen, J. 2005. Comparative infructescence morphology in Liquidambar (Altingiaceae) and its evolutionary significance. American Journal of Botany, 92:1234-1255. https://doi.org/10.3732/ajb.92.8.1234

Ickert-Bond, S.M., Pigg, K.B., and Wen, J. 2007. Comparative infructescence morphology in Altingia (Altingiaceae) and discordance between morphological and molecular phylogenies. American Journal of Botany, 94:1094-1115. https://doi.org/10.3732/ajb.94.7.1094

Ickert-Bond, S.M. and Wen, J. 2013. A taxonomic synopsis of Altingiaceae with nine new combinations. PhytoKeys, 31:21-61. https://doi.org/10.3897/phytokeys.31.6251 
Ker Gawler, J.B. 1816. Camellia japonica. The Botanical Register: Consisting of Coloured Figures of Exotic Plants, Cultivated in British Gardens; with Their History and Mode of Treatment, 2:212.

Kirkbride, J.H.J., Gunn, C.R., and Dallwitz, M.J. 2006. Family Guide for Fruits and Seeds, vers. 1.0. Accessed 5 May 2015. https://nt.ars-grin.gov/seedsfruits/keys/frsdfam/index.cfm ]

Kirkbride, J.H.J., Gunn, C.R., Weitzman, A.L., and Dallwitz, M.J. 2015. Legume (Fabaceae) Fruits and Seeds, Version 2. Accessed 5 May 2015. https://nt.ars-grin.gov/seedsfruits/keys/ fabaceae/index.cfm

Lesquereux, L. 1869. Species of fossil plants collected near Somerville, Fayette County, Tennessee, p. 426-428. In Safford, J.M. (ed.), Geology of Tennessee. S.C. Meecer, Printer to the State, Nashville.

Lesquereux, L. 1878. Contributions to the fossil flora of the Western Territories, Part II: The Tertiary flora. Government Printing Office, Washington.

Lindley, J. 1836. A Natural System of Botany: or a Systematic View of the Organisation (second edition). Longman, Rees, Orme, Brown, Green, and Longman, London.

Lindley, J. 1846. The Vegetable Kingdom; or, the Structure, Classification and Uses of Plants, Illustrated upon the Natural System. Bradbury \& Evans, London.

Link, J.H.F. 1829. Handbuch zur Erkennung der Nutzbarsten und am Häufigsten Vorkommenden Gewächse. Haude und Spener, Berlin.

Linnaeus, C. 1753. Species Plantarum: Exhibentes Plantas Rite Cognitas, ad Genera Relates, cum Differentiis Specificis, Nominibus Trivialibus, Synonymis Selectis, Locis Natalibus, Secundum Systems Sexuale Digestas. Tomus I [II]. Impensis Laurentii Salvii, Holmiae, Stockholm.

Linnaeus, C. 1768. Systema Naturæ per Regna Tria Naturæ, secundum Classes, Ordines, Genera, Species, cum Characteribus \& Differentiis. Tomus III. Impenis Laurentii Salvii, Holmiae, Stockholm.

Lu, A., Stone, D.E., and Grauke, L.J. 1999. Juglandaceae. Flora of China, 4:277-285.

Manchester, S.R. 1987. The fossil history of Juglandaceae. Monographs in Systematic Botany Missouri Botanical Garden, 21:1-137. https://doi.org/10.5962/bhl.title.154222

Manchester, S.R. 1989. Systematics and fossil history of the Ulmaceae. In Crane, P.R. and Blackmore, S. (eds.), Evolution, Systematics, and Fossil History of the Hamamelidae. Vol. 2. "Higher" Hamamelidae. Systematics Association Special Volume 40B. Clarendon Press, Oxford.

Manchester, S.R. 1994. Fruits and seeds of the middle Eocene Nut Beds Flora, Clarno Formation, Oregon. Palaeontographica Americana, 58:1-205.

Manchester, S.R., Chen, Z., Lu, A., and Uemura, K. 2009. Eastern Asian endemic seed plant genera and their paleogeographic history throughout the Northern Hemisphere. Journal of Systematics and Evolution, 47:1-42. https://doi.org/10.1111/j.1759-6831.2009.00001.x

Manchester, S.R., Grímsson, F., and Zetter, R. 2015. Assessing the fossil record of Asterids in the context of our current phylogenetic framework. Annals of the Missouri Botanical Garden, 100:329-363. https://doi.org/10.3417/2014033

Manchester, S.R and O'Leary, E.L. 2010. Phylogenetic distribution and identification of finwinged fruits. Botanical Review, 76:1-82. https://doi.org/10.1007/s12229-010-9041-0

Martynov, I. 1820. Techno-Botanical Dictionary. Imperial Russian Academy, St. Petersburg. (In Russian)

Maximowicz, C.J. 1873. Diagnoses plantarum novarum Japoniae et Mandshuriae. Bulletin de l'Academie Imperiale des Sciences de Saint-Pétersbourg, 18:275-296.

Meng, H., Su, T., Huang, Y., Zhu, H., and Zhou, Z. 2015. Late Miocene Palaeocarya (Engelhardieae: Juglandaceae) from southwest China and its biogeographic implications. Journal of Systematics and Evolution, 33(6):499-511. https://doi.org/10.1111/jse.12145

Mindell, R.A., Stockey, R.A., and Beard, G. 2007. Cascadiacarpa spinosa gen. et sp. nov. (Fagaceae): castaneoid fruits from the Eocene of Vancouver Island, Canada. American Journal of Botany, 94:351-361. https://doi.org/10.3732/ajb.94.3.351

Mindell, R.A., Stockey, R.A., and Beard, G. 2014. Cascadiacarpa exilis sp. nov.: new fruits of Fagaceae from the Eocene of British Columbia. Botany, 92:377-387. https://doi.org/10.3732/ ajb.94.3.351

Nakai, T. 1930. Hisi-Shokubutsu. Iwanami Shoten, Publishers, Tokyo.

Nelson, W.A. 1911. Clay Deposits of West Tennessee. Folk-Keelin Printing Co., Nashville. 
Nixon, K.C. 1997. Fagaceae. In Flora of North America Editorial Committee (ed.), Flora of North America North of Mexico, Volume 3. New York and Oxford.

O'Leary, E.L. 2007. Taxonomic Distribution of Modern Fin-Winged Fruits and the Fossil History of the Combretaceae in the United States Based on Fin-Winged Fruits. Master's Thesis, University of Florida, Gainesville, Florida.

Oishi, S. and Huzioka, K. 1942. On Pteroceltis from the Tertiary of Hokkaido and Tyosen. Journal of the Geological Society of Japan, 49:177-179. https://doi.org/10.5575/geosoc.49.177

Perleb, K. J. 1818. Versuch über die Arzneikräfte der Pflanze. Sauerländer, Aarau.

Pigg, K.B. and Wehr, W.C. 2002. Tertiary flowers, fruits, and seeds of Washington State and adjacent areas - Part III. Washington Geology, 30:3-16.

Potter, F.W. 1976. Investigations of angiopserms from the Eocene of southeastern North America: Pollen assemblages from Miller pit, Henry County, Tennessee. Palaeontographica, Abst. B, 157:44-96.

Potter, F.W. and Dilcher, D.L. 1980. Biostratigraphic analysis of middle Eocene floras of western Kentucky and Tennessee, p. 211-225. In Dilcher, D.L. and Taylor, T.N. (eds.), Biostratigraphy of Fossil Plants: Successional and Paleoecological Analysis. Dowden, Hutchinson and Ross Publishers, Stroudsburg, Pennsylvania.

Rafinesque, C.S. 1824. On a new tree of Kentucky forming a new genus Cladrastis fragrans. Cincinnati Literary Gazette (Natural History, NeoPhyton), 1:60.

Saporta, G. 1873. Etude sur la végétation du sud-est de la France. Supplément 1, Révision de la flore des Gypses d'Aix. Annales des Sciences Naturelles, Botanique, 5:81-244.

Serbet, R., Taylor, T.N., and Taylor, E.L. 2008. Ceratophyllum from southern Alberta, Canada: Extending the geological range of an extant group. Botany 2008: Annual Meeting of the Botanical Society of America, Vancouver, British Columbia, Canada. http:// www.2008.botanyconference.org

Stevens, P.F. 2001 onwards. Angiosperm Phylogeny Website. Version 14, July 2017, and more or less continuously updated since. http://www.mobot.org/MOBOT/research/APweb

Sun, B., Tao, J.R., Wang, X.Z., and Li, J.Y. 1999. Plant Fossils from Shanwang. Science and Technology Publishing House, Jinan, China.

Tschudy, R.H. 1973. Stratigraphic distribution of significant Eocene palynomorphs of the Mississippi Embayment. U. S. Geological Survey Professional Paper, 743B:1-24.

von Berchtold, F. and Presl, J.S. 1820. O Přirozenosti Rostlin aneb Rostlinář: obsahugjcj gedanj on ziwobytj rostlinném pro sebe az ohledu giných žiwoků podlé stawu nyněgssjbo znanj $\mathrm{k}$ rozssjřenj prirodnictwj, wpotaženj na užitećnost w rolnictwj hospodářstwj řemestech umenj $\mathrm{i}$ obchodu a w wztahowanj obzwlásstnjm obzwlásstnjm na lekarstwj. K.W. Kubersa, Praze.

Wang, H., Blanchard, J., and Dilcher, D.L. 2013. Fruits, seeds, and flowers from the Warman clay pit (middle Eocene Claiborne Group), western Tennessee, USA. Palaeontologia Electronica, 16.3.31A:1-73. https://doi.org/10.26879/320

Watson, L. and Dallwitz, M.J. 1992 onwards. The families of flowering plants: descriptions, illustrations, identification, and information retrieval. Accessed 22 April 2014. http://deltaintkey.com

Wen, J. 2001. The evolution of Araliaceae: a phylogenetic analysis based on ITS sequences of nuclear ribosomal DNA. Systematic Botany, 26:144-167. https://doi.org/10.1007/ BF02805403

Wen, J. and Frodin, D.G. 2001. Metapanax, a new genus of Araliaceae from China and Vietnam. Brittonia, 53(1):116-121.

Wheeler, E.A. and Manchester, S.R. 2014. Middle Eocene trees of the Clarno Petrified Forest, John Day Fossil Beds National Monument, Oregon. PaleoBios, 30:5-114.

Xiang, Q.-B. and Lowry, P.P.I. 2007. Araliaceae. Flora of China, 13:435-491.

Xiang, Q.-B. and Lowry, P.P.I. 2008. Araliaceae. Accessed 22 February 2008. http:// www.efloras.org

Zavada, M.S. and Crepet, W.L. 1981. Investigations of angiosperms from the middle Eocene of North America: Flowers of the Celtidoideae. American Journal of Botany, 68:924-933. https:// doi.org/10.1002/j.1537-2197.1981.tb07808.x 